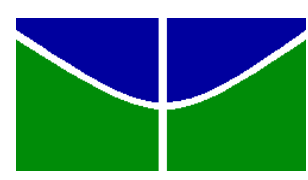

Universidade de Brasília

Faculdade de Educação

Programa de Pós Graduação em Educação

A ECOLOGIA DA VADIAÇÃO: OS SABERES NO GRUPO N'ZAMBI DE CAPOEIRA ANGOLA EM FLORIANÓPOLIS - SANTA CATARINA

ISABELA GUIMARÃES RABELO

Brasília - DF

Julho/ 2014 
ISABELA GUIMARÃES RABELO

A ECOLOGIA DA VADIAÇÃO: OS SABERES NO GRUPO N'ZAMBI DE CAPOEIRA ANGOLA EM FLORIANÓPOLIS - SANTA CATARINA

Dissertação de Mestrado submetida ao Programa de Pós-Graduação em Educação da Faculdade de Educação da Universidade de Brasília, como requisito parcial à obtenção do título de Mestra em Educação, área de concentração Ecologia Humana e Educação Ambiental. Orientadora: Cláudia Pato.

Brasília - DF

Julho/2014 
Rabelo, Isabela Guimarães, 1985 -

A ecologia da vadiação: os saberes no grupo nZambi de capoeira angola em Florianópolis - Santa Catarina / Isabela Guimarães Rabelo. 2014.

Orientadora: Cláudia Pato

Dissertação de Mestrado - Universidade de Brasília, Faculdade de Educação, Programa de Pós Graduação, 2014.

Referências Bibliográficas: f. 85- 87.

1. Monocultura de saberes. 2. Ecologia de saberes. 3. Capoeira angola. 4. Grupo nZambi de capoeira angola. 5. Cooperação. I. Pato, Cláudia Márcia Lyra. II. Universidade de Brasília. Faculdade de Educação. Programa de Pós-Graduação em Educação. III. Título. 


\author{
UNIVERSIDADE DE BRASÍLIA \\ FACULDADE DE EDUCAÇÃO \\ PROGRAMA DE PÓS-GRADUAÇÃO EM EDUCAÇÃO
}

\title{
A ECOLOGIA DA VADIAÇÃO: OS SABERES NO GRUPO N'ZAMBI DE CAPOEIRA ANGOLA EM FLORIANÓPOLIS - SANTA CATARINA
}

\section{Isabela Guimarães Rabelo}

Dissertação de Mestrado submetida ao Programa de Pós - Graduação em Educação da Faculdade de Educação da Universidade de Brasília como parte dos requisitos necessários à obtenção do grau de Mestre em Educação, na área de concentração de Educação Ambiental e Ecologia Humana.

\section{Banca Examinadora:}

Prof $^{\text {a }}$ Dr $^{\text {a }}$ Claudia Pato ( Orientadora )

Universidade de Brasília - Faculdade de Educação

Prof $^{\circ} \operatorname{Dr}^{\circ}$ Irineu Tamaio

Universidade de Brasília - Campus Planaltina

Prof $^{\mathrm{a}}$ Dr $^{\mathrm{a}}$ Leila Chalub Martins

Universidade de Brasília - Faculdade de Educação

$\operatorname{Prof}^{\mathrm{a}} \mathrm{Dr}^{\mathrm{a}}$ Teresa Cristina Siqueira Cerqueira

Universidade de Brasília - Faculdade de Educação 
IÊ!

Desde que aqui cheguei

Sei que num vou lhe contá

Quanta coisa aprendi

Vendo a mestra jogá

Vi que não sabia nada

Nem ela sabia tudo

Mas vivia o que dizia

E o que dizia era profundo

Essa vida é muito boa

Mas num alisa ninguém

Olho vivo

E silêncio

Valem mais que um vintém

Camaradinha

Aquinderreis

Iê, aquinderreis, camará

Viva minha mestra

Iê, viva minha mestra, camará

A capoeira

Iê, a capoeira, camará

Volta do mundo

Iê, volta do mundo, camará

Vamo simbora

Iê, vamo simbora, camará

(Isabela Guimarães) 


\section{AGRADECIMENTOS}

Às forças que me acompanham. Às encruzilhadas. Ao mar, pelas surras e acolhidas. Às matas, pelos descaminhos e achados. Só fica de pé quem já caiu.

Aos meus pais, pela infância livre, pelas árvores nas quais subi, pelos rios em que banhei e pela peneira cheia de piabinha. Agradeço aos livros e aos diversos incentivos para seguir com vontade.

À minha orientadora Cláudia Pato, por me possibilitar concluir essa tarefa.

Aos meus professores Sal, Luane, Ga, Cled e Mari, gratidão profunda.

Aos camaradas do núcleo do nZambi em Brasília, pela amizade sincera e troca fortalecedora.

Aos camaradas do núcleo do nZambi em Florianópolis, por me receberem em suas casas e compartilharem algumas doses de mistério.

À mestra Elma, porque o olhar já diz tudo.

Às irmãs e irmãos da vila. Obrigada por vivenciarem comigo meus dias mais difíceis, vocês são foda!!!

Por inúmeros motivos entrelaçados nesse momento, agradeço à: Pedro Mesquita, Periquito, Fernanda Fagundes, Marina Bicalho, Renata Matos, Dina, Aline Dandara, Alvarenga, Vogly, Abayomi Mandela, Izabele Pimenta, Driquinha, Artuzim, Cocada, Samarica Parteira, Karina Bortoli, Carol, Ju del Lama, Clara Ramthum, Júlia Guerra, Clarisse Stephan, Ana Emília,Eunice, Duru, Kata, Flavinha, Maroja, Pati e Pablo. 


\begin{abstract}
RESUMO
A admissão do conhecimento científico como forma mais legítima de entendimento da realidade nos coloca diante da exclusão das infinitas manifestações de saber que existem no mundo em uma lógica de monocultura dos saberes. Para confrontar essa realidade podemos constatar a nossa diversidade epistemológica por meio de uma ecologia dos saberes. Neste sentido a ciência não é mais percebida como a principal forma de entendimento da realidade, além dela há infinitos saberes com voz suficiente para dialogar de forma horizontal com a ciência, dentre eles destacamos a capoeira angola. Esta é percebida aqui como uma manifestação da cultura popular afro-brasileira que conta com mestras e mestres na transmissão de saberes via oralidade. Daí surge nosso principal objetivo que é refletir sobre a capoeira angola como saber a partir daquilo que emerge dos processos de ensino e aprendizagem do grupo nZambi de capoeira angola em Florianópolis - SC. Assim foi possível evidenciar o trabalho de uma das primeiras mestras de capoeira angola, Elma Silva Weba, a mestra Elma. Para dar cabo desta demanda realizamos um estudo de caso no ambiente do grupo nZambi de capoeira angola em Florianópolis - SC. O estudo de caso foi possível através de uma pesquisa de campo, onde participamos durante três meses das atividades do grupo por meio da observação participante, sendo que a entrevista semi-estruturada e o relato oral foram também instrumentos de coleta de dados. No grupo nZambi de capoeira angola em Florianópolis - SC, nos deparamos com formas sutis de transmissão de saber em que o capricho e o silêncio eram elementos fundamentais de uma experiência coletiva e comunitária, possível por meio do aprendizado da cooperação.
\end{abstract}

PALAVRAS-CHAVE: ecologia de saberes, capoeira angola, educação ambiental, valores humanos, ecologia da vadiação. 


\begin{abstract}
The admission of scientific lore as the most legitimate way of understanding reality places us up the exclusion of numerous knowledge expressions that exist in the world, in a knowing monoculture logic. To confront this reality we can think over the finding of our epistemological variety by means of a knowledges' ecology. In this sense, science isn't perceived anymore as the main manner of understanding reality, further there are numerous knowledges that hold sufficient voice to dialog horizontally with it, among them we highlight capoeira angola. This one is understood here as a manifestation of afro-brazilian popular culture the counts with male and female master in the oral transmission of knowing. There from arises our main objective - think about capoeira angola as a knowledge from what emerges in the guideline/ apprenticeship processes of nzambi capoeira angola group in Florianópolis - SC. Thus it was possible to evidence the task of one of the first capoeira angola female masters, Elma Silva Weba, master Elma. To accomplish this demand a case study was realized in the group environment. This case study was possible by means of participating observation, and the semi - structured interview and the oral account were also data collection tools. In nZambi capoeira angola group we acrossed subtle ways of propagating knowledge in which whim and silence were fundamental elements of a collective and communitary expererience, possible by means of cooperation learning.
\end{abstract}

KEYWORDS: knowledges' ecology, capoeira angola, environmental education, human values, ecology of vagrancy. 


\section{LISTA DE FIGURAS}

Figura 1 - Roda de capoeira no Terreiro do Vô Congo. Evento: "Sob o olhar dos

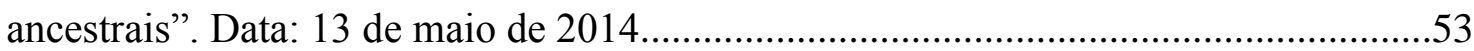

Figura 2 - Ilustração na técnica nanquim sobre papel. Título: "Bruxas atacam um pescador" .58

Figura 3 - Mapa das povoações da Ilha de Santa Catarina. Destaque para o ponto vermelho onde se encontra a região da Costa de Dentro .60

Figura 4 - Entrada da Costa de Dentro - fachada da Escola Municipal da Costa de Dentro e entrada do CODEN com placa de divulgação das aulas de capoeira angola com o grupo nZambi 61

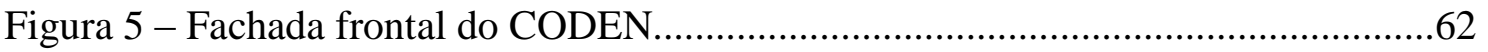

Figura 6 - Fachada frontal da Igreja de São Pedro - Pântano do Sul.............................64

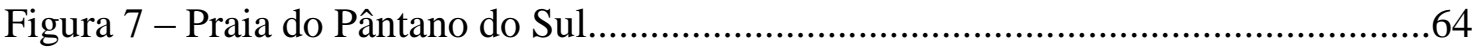

Figura 8 - Treino de berimbau no salão do CODEN.....................................................73

Figura 9 - Roda de capoeira em frente à Igreja de São Pedro na região do Pântano do Sul. .79

Figura 10 - Roda de capoeira no centro de Florianópolis .80 
LISTA DE TABELAS

Tabela 1 - Caracterização dos Participantes da Pesquisa................................................62 


\section{SUMÁRIO}

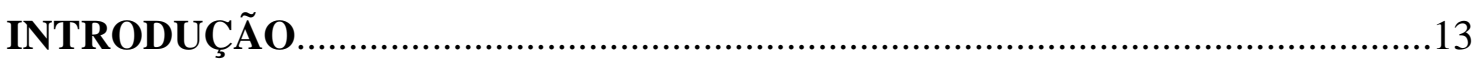

CAPÍTULO 1 - QUAL O RUMO DA PROSA? ....................................................16

1.1 Da monocultura de saberes para uma ecologia de saberes.............................16

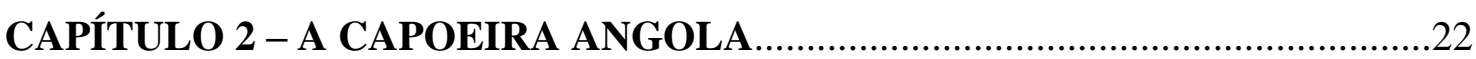

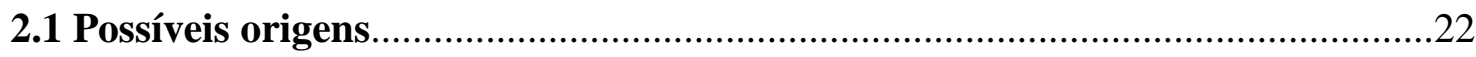

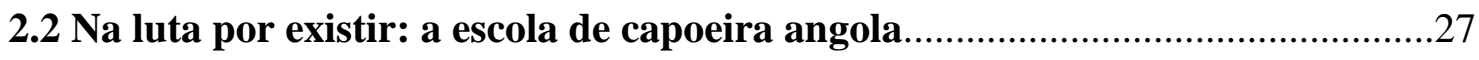

CAPÍTULO 3 - A CAPOEIRA ANGOLA: UMA ESCOLA DE CAPOEIRA........32

CAPÍTULO 4 - METODOLOGIA - AS ENCRUZILHADAS DE UM ESTUDO:

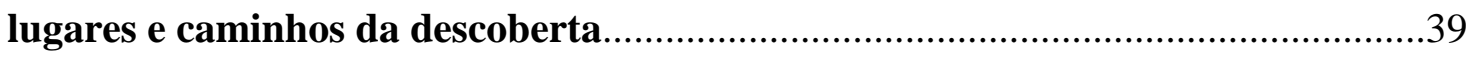

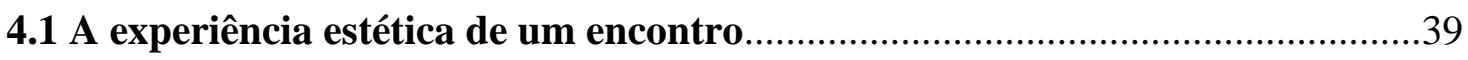

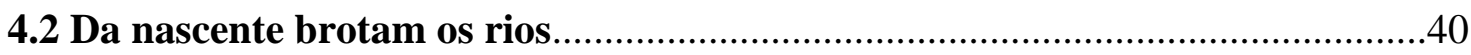

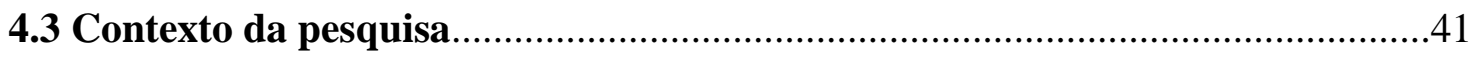

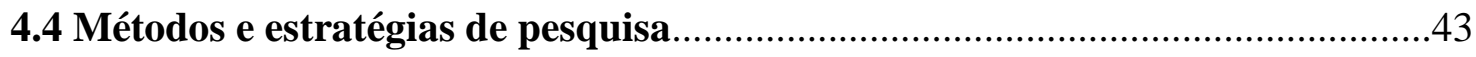

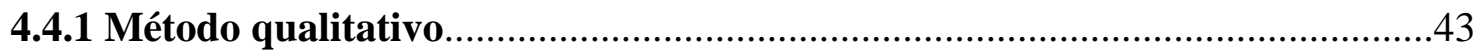

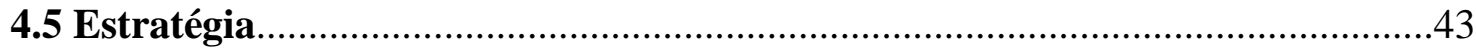

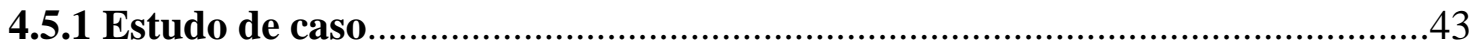

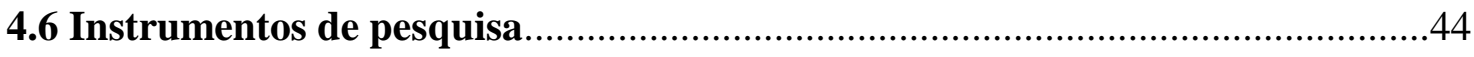

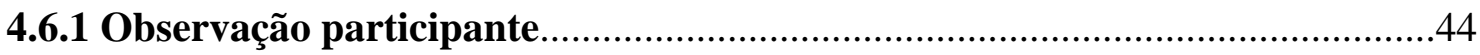

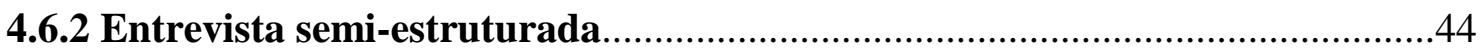

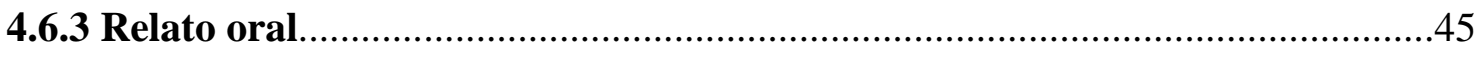

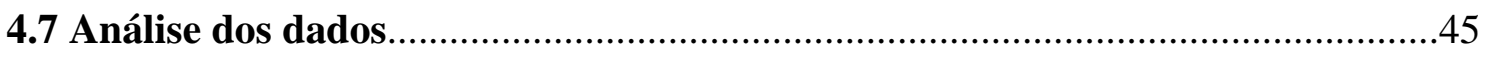

CAPÍTULO 5 - “ CORTA A CABAÇA ESPALHA A SEMENTE”......................47

5.1 Trajetórias do grupo nZambi de capoeira angola...........................................47 
CAPÍTULO 6 - QUE VENTO TE TROUXE À ILHA DAS BRUXAS? .57

6.1 Nossa escola e nossos camaradas .61

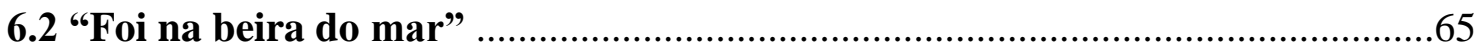

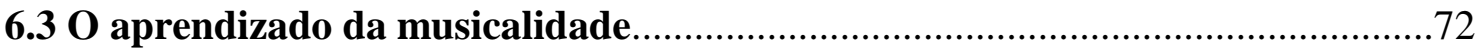

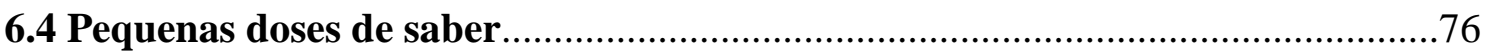

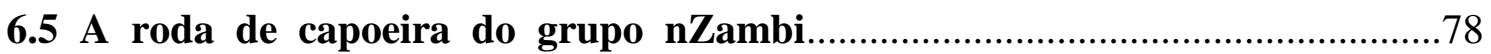

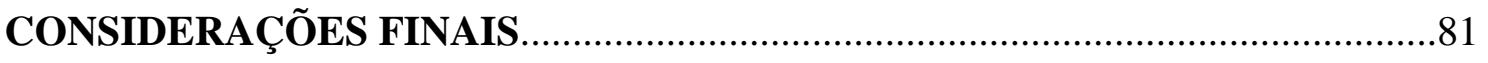

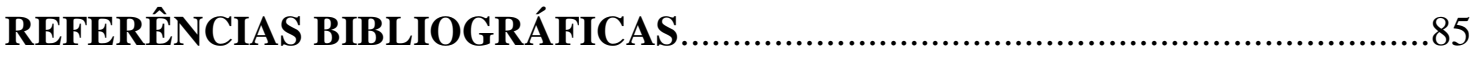

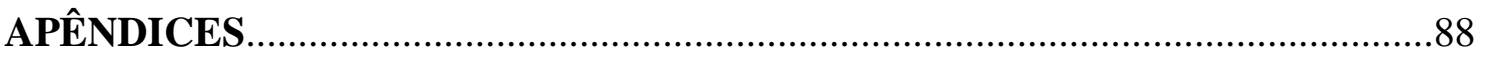

APÊNDICE A - ROTEIRO DE ENTREVISTA SEMIESTRUTURADA No 1

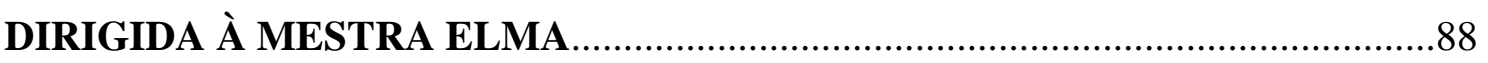

APÊNDICE B - ROTEIRO DE ENTREVISTA SEMIESTRUTURADA $\mathbf{N}^{\circ} 2$

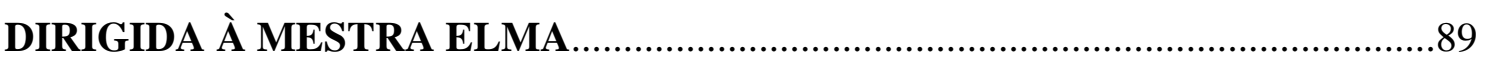

APÊNDICE C - ROTEIRO DE ENTREVISTA SEMIESTRUTURADA No 3

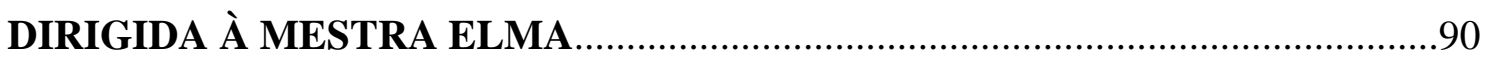

APÊNDICE D - ROTEIRO DE ENTREVISTA SEMIESTRUTURADA $\mathbf{N}^{\circ} 4$ DIRIGIDA AOS CAMARADAS DO GRUPO NZAMBI..................................91

APÊNDICE E - ROTEIRO DE ENTREVISTA SEMIESTRUTURADA No 5 DIRIGIDA À VICE-PRESIDENTA DO CODEN............................................... 92

APÊNDICE F - ROTEIRO DE OBSERVAÇÃO .................................................93

APÊNDICE G - TERMOS DE CONSENTIMENTO PARA REALIZAÇÃO DA

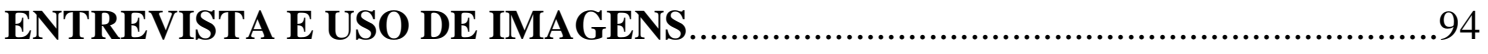




\section{INTRODUÇÃO}

O advento da ciência moderna proporcionou inúmeros benefícios para a manutenção da vida humana no planeta terra, ampliando nosso leque de possibilidades na compreensão das nossas dúvidas diante dos fenômenos que estão a nossa volta. Porém, estamos em um momento onde mais uma vez percebemos a necessidade de refletir sobre os impasses do desenvolvimento científico.

Quando dizemos “mais uma vez”, nos reportamos ao fato de que esta não é uma reflexão exclusiva deste momento. Também podemos afirmar que nada se esgotou. Estamos em curso, até mesmo porque ainda vivemos em uma sociedade que tem como alguns dos seus alicerces os pensamentos científicos e filosóficos ocidentais.

Existem muitos eixos de estudo para essa questão. Podemos refletir sobre a ciência a partir dos modos do fazer científico, também sobre os impactos que muitas descobertas científicas veem imprimindo ao nosso ambiente, assim como podemos refletir sobre as interações entre o conhecimento científico e os infinitos saberes que tecem os fios da nossa realidade.

Neste estudo, não elaboramos uma discussão profunda sobre os modos do fazer científico, porém vale ressaltar que este é um trabalho onde a distância entre "sujeita" e "objeto" é irrisória. A pesquisadora também foi "objeto" de pesquisa sendo profundamente provocada neste processo,

(...) em vez da prioridade da investigação da relação causa-efeito, a prioridade da investigação dos meios para atingir objetivos; em vez da separação entre sujeito e objeto, o objeto que é sujeito; em vez da separação entre observador e observado, o observador na observação; em vez da separação entre o pensar e o agir, a interactividade entre ambos no processo de investigação (SANTOS, 2010, p. 141).

Sobre os impactos do conhecimento científico no nosso ambiente, na nossa casa, o planeta Terra; podemos destacar estudos como os de Hanna Arendt, que desde a década de 1950, quando publicou A condição humana, trazia alguns contrapontos do conhecimento científico. Por mais que as descobertas científicas nos permitissem chegar à lua, como se apresentava de fato uma ciência que muitas vezes se colocava a serviço da guerra? Obviamente, as questões levantadas por Hanna Arendt não se limitam a esta, além disso, foram ainda mais profundas. Porém, cabe indicar que este estudo ao se configurar, trilhou por esses caminhos. 
Nesse sentido nos debruçamos mais nas reflexões em torno das interações entre o conhecimento científico e outros saberes, através de dois conceitos que são apresentados por Boaventura de Souza Santos (2010), em A gramática do tempo: para uma nova cultura política, são eles: a monocultura dos saberes (p. 102) e a ecologia dos saberes (p. 107). Por meio da monocultura dos saberes o autor constata a predominância do conhecimento científico, como forma legítima de interpretação, explicação e intervenção na realidade. Este aspecto confere à ciência a hegemonia nos rumos do conhecimento, sendo um ponto fundamental para a manutenção do sistema capitalista. Dentre bússolas e caravelas, vivemos sob uma ótica de desenvolvimento em que comunidades indígenas e africanas são atropeladas tanto em nível material como simbólico, a racionalidade moderna é um dos temperos dessa linha de desenvolvimento. Estudioso pós-colonialista, Boaventura de Souza Santos confronta a lógica da monocultura dos saberes por meio da ecologia dos saberes.

A ecologia de saberes confronta a lógica monocultural ao conferir credibilidade às infinitas manifestações de saber que conferem sentido às infinitas possibilidades de interpretação, explicação e intervenção na realidade. Neste sentido podemos dizer que não há no universo policromático da vida, uma única forma de lidar com os contextos que nos tangem. Contamos com diversidades nas artes, na alimentação, na medicina e também no emprego de tecnologias. O conhecimento científico não é a única possibilidade de compreensão e intervenção na vida.

Diante da problemática apresentada, um dos objetivos deste trabalho foi trazer para este diálogo uma manifestação da cultura popular afro-brasileira, a capoeira angola. Isto porque, a capoeira, desde o séc XIX trava inúmeras batalhas por existir. Ora criminalizada e muitas vezes à mercê da regulamentação estatal, a capoeira angola persiste como política de resistência frente à marginalização que o pensamento hegemônico confere às práticas sociais que não canonizou.

Mais especificamente, buscamos refletir sobre a capoeira angola como saber. Eis a contribuição deste trabalho para a educação. Enquanto saber, podemos conhecer algumas dinâmicas de ensino e aprendizagem que fundamentam o processo de formação das angoleiras e angoleiros, tais como a oralidade, a memória, ancestralidade, a circularidade e assim por diante. Esse processo de formação é ritualístico, normalmente transmitido por mestras e mestres nos grupos de capoeira, e vem embebido de filosofia e sabedoria, onde a capoeira angola se apresenta como uma escola de vida. 
As mestras e mestres de capoeira angola exercem um papel fundamental na transmissão deste saber. Vale ressaltar que a emergência das mulheres no universo dessa manifestação é recente. Destes pontos surge nosso principal objetivo, possível no encontro com uma das principais mestras de capoeira angola hoje no Brasil: Elma Silva Weba, a mestra Elma. A fim de aprofundar nossas reflexões em torno da capoeira angola enquanto saber, realizamos um estudo de caso das práticas de ensino e aprendizagem do grupo nZambi de capoeira angola, em Florianópolis - Santa Catarina, local onde reside a mestra Elma e onde desenvolve diversas frentes de trabalho.

Nosso foco foi direcionado ao trabalho desenvolvido no Conselho Comunitário da Costa de Dentro (CODEN), onde a capoeira angola é transmitida aos adultos e crianças em ambiente de desenvolvimento elástico (SENNET, 2012, p. 23), onde não há segregação por idade, gênero, nem etnia. Realizamos três meses de pesquisa de campo, por meio da observação participante e também através de entrevistas, buscando apreender elementos que emergiam dos ensinamentos transmitidos pela mestra Elma para, assim, aprofundar o olhar sobre a capoeira, bem como sobre seus processos de ensino e aprendizagem que nos permitem ampliar o diálogo sobre educação, a legitimidade dos saberes, a ecologia dos mesmos e no caso da capoeira angola sobre a ecologia da vadiação. 


\title{
CAPÍTULO 1 - QUAL O RUMO DA PROSA?
}

\subsection{Da monocultura de saberes para uma ecologia de saberes}

Desde que o conhecimento científico ocupou os pedestais de legitimidade do que é sabível, vivenciamos uma trajetória em que saberes como a capoeira angola travam inúmeras batalhas por existir, as coisas começaram a assim se dar com o reconhecimento da modernidade ocidental como paradigma sociocultural. Este, reduzindo nossas possibilidades de emancipação do sistema capitalista, adquiriu uma total preponderância sobre outros saberes, neutralizando-os,

\begin{abstract}
convertendo a solidariedade numa forma de caos, e, portanto de ignorância e o colonialismo numa forma de saber, e, portanto, de ordem. Neste processo, a ciência moderna, inicialmente um tipo de conhecimento, assumiu uma preponderância total, reclamando para si o monopólio do conhecimento válido e rigoroso, o que ocorreu com a consagração da epistemologia positivista (...). Convertida em conhecimento uno e universal, a ciência moderna ocidental, ao mesmo tempo que se constituiu em vibrante e inesgotável fonte de progresso tecnológico e desenvolvimento capitalista, arrasou, marginalizou ou descredibilizou todos os conhecimentos não científicos (...) tanto no Norte como no Sul (SANTOS, 2010, p. 155).
\end{abstract}

Esse fenômeno estudado por Boaventura de Souza Santos (2010) permite perceber o quanto de experiência estamos desperdiçando ao acreditar que o conhecimento científico, revestido da compreensão ocidental do mundo, seja a única forma legítima de conhecer a realidade, silenciando a voz dos saberes não científicos, que exteriores ao cânone ocidental, continuam ainda fora do debate sobre o mundo. Tanto a filosofia quanto a ciência produzida no ocidente, há duzentos anos, foram o alimento para a formação do que Boaventura (2010) denomina de conhecimento hegemônico, sendo que seu desenvolvimento teve como cenários sócio-políticos, a consolidação do Estado Liberal na Europa e na América do Norte, as Revoluções Industriais, o desenvolvimento capitalista, o colonialismo e o imperialismo.

O fato é que estamos cada dia mais no limiar da existência, seja por meio do caos e problemáticas urbanas, seja pela iminência de inúmeros desastres ecológicos. A nossa realidade tem sido vivenciada e compreendida por meio de inúmeras dicotomias hierarquicamente sedimentadas ao logo dos anos, de modo que prevalece o conhecimento científico em detrimento do conhecimento tradicional, o homem em detrimento da mulher, a cultura em detrimento da natureza, o branco em detrimento do 
negro, o ocidente em detrimento do oriente, e assim por diante (SANTOS, 2010). Tamanha restrição reverbera em nossos modos de vida.

Não temos motivos para duvidar da nossa atual capacidade de destruir toda a vida orgânica da Terra (ARENDT, 2007), de modo que o conhecimento científico tem sido um dos instrumentos para tal empreendimento. Vamos construindo um modelo de sociedade, onde o sentido da vida está fundamentado no acúmulo e desperdício de riquezas materiais, de bens e serviços, onde apenas aqueles que tudo podem adquirir desfrutam dessa curta passagem pela terra. "Para realizar este propósito, nos ajudam a ciência, que conhece os mecanismos da terra, e a técnica, que faz intervenções nela para benefício humano. E isso se fará com a máxima velocidade possível" (BOFF, 1995, p. $15)$.

Apontar algumas problemáticas que giram em torno dos serviços que tem prestado a ciência, não pretende estabelecer uma abordagem maniqueísta como se o conhecimento científico fosse o maior demônio dos últimos tempos. De fato acreditamos na relevância de repensarmos a ciência, que até então se constitui como horizonte certo de um conhecimento que se pretende utilitário e funcional, que antes mesmo de compreender o real busca transformá-lo e dominar (SANTOS, 2010). Repensar os rumos do conhecimento científico não significa torná-lo obsoleto em nossos discursos, ignorando que desde o fogo, a vida humana gira em torno também das descobertas. Sem anjos e demônios, considerando que nem sempre os anjos são tão bons e os demônios tão ruins, a intenção é reconhecer que para além da ciência, há em nosso mundo outros saberes e formas de compreensão da realidade.

A hegemonia do conhecimento científico se fundamenta numa ideia de totalidade e supremacia deste saber, de modo que tudo aquilo que não se encaixa nos moldes racionalistas de criação e interpretação do real está submetido à não existência. Os saberes que ainda hoje operam à margem da ciência não existem, porque são produzidos como não existentes por não terem garantida a sua credibilidade como saber. Este fenômeno que Boaventura de Souza Santos (2010) denomina de monocultura do saber se caracteriza da seguinte forma:

É o modo de produção de não-existência mais poderoso. Consiste na transformação da ciência moderna e da alta cultura em critérios únicos de verdade e de qualidade estética, respectivamente. A cumplicidade que une as "duas culturas" reside no facto de ambas se arrogarem ser, cada uma no seu campo cânones exclusivos de produção de conhecimento ou de criação artística. Tudo o que o cânone não legitima 
ou reconhece é declarado inexistente. A não-existência assume aqui a forma de ignorância ou de incultura (p.103).

Este mecanismo de produção da não existência é o que legitima a supremacia do conhecimento e filosofia ocidental em relação às diversas manifestações de compreensão e vivência da realidade, tais como os saberes e práticas tradicionais que podem se expressar em conhecimentos vivenciais da medicina, religiosidade, corporeidade, musicalidade, e assim por diante. Quando muito, estes saberes colocados à margem, são considerados alternativos à estrutura hegemônica de produção de legitimidade, não raro nos deparamos com discursos capitalizados de sustentabilidade e até mesmo de ecologia onde as diversas manifestações da cultura indígena, africana e oriental, são concebidas como práticas alternativas de cura, de vivência do sagrado e do aprendizado. Quando não se tornam artigos de consumo.

Esse é um ponto importante para o qual Boaventura de Souza Santos (2010) nos chama a atenção. Acreditar que as diversas práticas não hegemônicas de saber sejam alternativas aos conhecimentos ocidentais, é o mesmo que manter a hierarquia dicotomizada, onde o conhecimento científico e a filosofia ocidental continuam ocupando no pedestal a supremacia de totalidade. Nesse sentido partimos da ideia de que saberes como a capoeira angola, não se constituem como práticas alternativas, para além disso representam uma das infinitas totalidades que constituem nosso mundo, que enquanto tal é um saber tão inacabado quanto o conhecimento científico.

Refletir a partir da ecologia dos saberes ou mesmo a partir de uma ecologia de práticas de saberes é reconhecer a presença de saberes plurais e concepções distintas sobre a dignidade humana e sobre o mundo. É reconhecer a diversidade infinita de saberes, onde toda forma de conhecimento é contextual e parcial. "Não há nem conhecimentos puros, nem conhecimentos completos; há constelações de conhecimentos" (SANTOS, 2010, p. 154).

Neste sentido é possível confrontar a lógica da monocultura do saber, por uma lógica que desmistifique a supremacia do saber científico sobre todos os demais saberes. Aqui percebemos que a faceta mais perversa da monocultura dos saberes, é a sua relação com a manutenção do sistema capitalista, bem como dos paradigmas e valores que o sustem:

A actual reorganização global da economia capitalista assenta, entre outras coisas, na produção contínua e persistente de uma diferença epistemológica, que não reconhece a existência em pé de igualdade, 
de outros saberes, e que por isso se constitui, de facto, em hierarquia epistemológica, geradora de marginalizações, silenciamentos, exclusões ou liquidações de outros conhecimentos. Essa diferença epistemológica inclui outras diferenças - a diferença capitalista, a diferença colonial, a diferença sexista - ainda que não esgote nelas. A luta contra ela, sendo epistemológica, é também anti-capitalista, anticolonialista e anti-sexista. É uma luta cultural (SANTOS, 2010, p. 153).

Nessa luta cultural que reconhece diferentes saberes reconhece também diferentes modos de vida, logo diferentes modos de interação nos ambientes pelos quais transitamos. A ecologia dos saberes também reconhece a incompletude do conhecimento, e justamente por isso é uma ecologia. Como afirma Boaventura de Souza Santos (2010), é uma ecologia porque reconhece a pluralidade dos saberes heterogêneos, sua autonomia e até mesmo a articulação sistêmica, dinâmica e horizontal. "A ecologia de saberes assenta na independência complexa entre os diferentes saberes que constituem o sistema aberto do conhecimento em processo constante da criação e renovação. O conhecimento é interconhecimento, é reconhecimento, é auto-conhecimento." ( p. 157).

Partimos do princípio da incompletude de todos os saberes (Idem, Ibidem, p. 107) como condição para o diálogo epistemológico entre a capoeira angola, o conhecimento científico e os diversos dados coletados nesta pesquisa. Trazemos a capoeira angola como norteadora do debate não para que seja ela agora a senhora da verdade, mas sim por acreditar que evidenciá-la é um compromisso político e subjetivo, que busca somar esforços à visibilidade do que até hoje tem sido oprimido como ausente, inexistente. Buscamos confrontar a lógica da monocultura de saberes, na identificação da capoeira angola como saber que tem em sua abordagem outros critérios de rigor que operam credivelmente nas práticas sociais. Esse confronto que para Boaventura (2010) é possível por meio de uma ecologia dos saberes, gera uma credibilidade contextual que deve ser considerada suficiente para que a capoeira angola tenha legitimidade para participar de debates epistemológicos com outros saberes, assim como o saber científico.

A capoeira angola é um saber, uma manifestação da cultura popular afrobrasileira que se expressa por meio de uma corporeidade e musicalidade própria. Carrega fundamentos ancestrais de matriz africana, sendo um saber transmitido via oralidade por mestras e mestres à discípulas e discípulos. É profundamente ritualística, sagrada e sutil. Representa uma escola de vida, onde os aprendizados de sua 
corporeidade e musicalidade estão embebidas dos ensinamentos da boa sobrevivência e do diálogo habilidoso. Ainda assim, retratar a trajetória e as singularidades da capoeira não é tarefa simples, por isso recorremos a diversos referenciais de pesquisadores da temática, em especial às publicações e entrevistas de antigos mestres e mestras da arte.

Os principais espaços de aprendizagem da capoeira angola nos tempos de hoje, são os grupos de capoeira. Em conjunto, em comunidade seguem linhas de ensinamentos que a todo instante dialogam. O diálogo dos corpos nos jogos de capoeira, ou mesmo o diálogo dos músicos na melodiosa e rítmica conversa dos berimbaus com a percussão favorecem o desenvolvimento daquilo que Richard Sennet descreve como habilidades dialógicas ( SENNET, 2012, p. 17). Para o autor a habilidade para o diálogo se desenvolve a partir da observação e sensibilidade para a escuta, no caso da capoeira angola, quando nos colocamos à disposição dos olhares, movimentos e sons podemos ampliar a capacidade de entendimento dos outros e construir nossas conversas através de inusitados jogos de perguntas e respostas.

O entendimento da capoeira angola como uma escola de aprendizado em grupo possibilitou um diálogo com o sociólogo e músico, Richard Sennet. Na obra intitulada Juntos: os rituais, os prazeres e a política da cooperação ( 2012), o autor reflete sobre os diversos aspectos dos trabalhos e atividades coletivas que contribuem para uma formação humana colaborativa, cuidadosa, dialogada e cooperativa. Ao observar os trabalhos também em oficinas de luteria, percebe a importância do silêncio, da observação e da escuta para o aprendizado da cooperação.

Na obra de Richard Sennet, encontramos elementos que ampliaram a nossa compreensão sobre a capoeira angola como uma escola de aprendizagem coletiva onde aprendemos "muito mais que capoeira". Aprendemos valores de coletividade que podem nos trazer a reflexão sobre a sociedade individual na qual vivemos.

Neste sentido, este estudo se dedicou a compreender a capoeira angola na história e no tempo, desde as suas possíveis origens até os processos de luta por existência e legitimidade que culminaram na organização da capoeira em uma escola chamada capoeira angola. Em outro momento, buscamos compreender a escola de capoeira angola enquanto saber, por meio das suas dinâmicas de ensino e aprendizagem, bem como por meio dos seus fundamentos e da sua filosofia que se manifesta na vadiação que ensina angoleiras e angoleiros o jogo da vida. Vale ressaltar que a 
vadiação é o modo como a comunidade capoeira também entende a prática de estar no ambiente da capoeiragem. Vadiar é brincar, é jogar capoeira, é estar na roda.

O momento seguinte desta pesquisa se revelou por meio de uma vivência considerada profunda e transformadora. A fim de visionar os diversos ângulos de ensino e aprendizagem da capoeira angola, foi realizado um estudo de caso por meio de uma experiência compartilhada com os camaradas do núcleo do grupo nZambi de capoeira angola na Ilha de Florianópolis-Santa Catarina. Este foi considerado um ponto de grande relevância para este estudo porque o grupo nZambi de capoeira angola foi o principal espaço de experimentação estética desta pesquisa (PEREIRA, 2011). Neste sentido, buscamos refletir sobre a capoeira angola como saber, a partir daquilo que emergia das práticas de ensino e aprendizagem deste grupo de capoeira angola. 


\section{CAPÍTULO 2 - A CAPOEIRA ANGOLA}

\subsection{Possíveis Origens}

Se os africanos escravizados nas Américas lograram adaptar, apesar das condições terrivelmente adversas, suas religiões e seus rituais, assim como suas festas e danças de umbigadas, não seria lógico que também trouxessem para cá seus jogos de combate e suas artes marciais? (ASSUNÇÃO; COBRA MANSA, 2009, p.

64).

Não é possível dizer onde começa e nem mesmo onde vai dar o novelo da capoeira. Ela é infinita e ancestral. Os elementos que a constituem são de matriz africana e passaram a compor o cenário da cultura brasileira com a chegada dos negros africanos escravizados no Brasil. Dominados pela tecnologia de guerra européia foram uma das mãos de obra para a ocupação do território brasileiro, por meio dos diversos aportes civilizatórios da África para o Brasil. Algumas regiões foram especialmente relevantes nesse processo, como é o caso de Angola.

Práticas religiosas, conhecimentos técnicos agrícolas e de mineração, valores sociais, costumes da vida cotidiana e hábitos de alimentação, entre outros elementos, fizeram parte da bagagem cultural que os escravizados trouxeram para a formação de nosso país (LIMA, 2009, p.11).

A origem da capoeira é assunto debatido e controverso, são muitas proposições que não chegam a revelar um ponto inicial e nem mesmo como e quando tenha principiado a sua manifestação. Há estudos realizados até então em torno da temática, que versam sobre sua ancestralidade africana, e mais especificamente como uma manifestação da cultura popular afro-brasileira que carrega em seu bojo ritualístico diversos elementos da região costeira central do continente africano, onde se situam na atualidade Angola e Congo.

Manifestações religiosas como os calundus, de forte presença entre os escravos trazidos da região Congo-Angola, estão na origem de religiões afro-brasileiras, como o candomblé na Bahia. Há indícios de que a arte da capoeira tem origem na “ dança da zebra”, o n’golo do sul de Angola. (Idem, Ibidem, p.11-12). 
Os indícios sobre o fato de que a capoeira tenha sua origem no n'golo, foram a temática de um estudo publicado por Mathias Rohrig Assunção e Mestre Cobra Mansa (2009), os pesquisadores apontam que, na década de 1960, o mestre Pastinha (18891981), um dos mais importantes capoeiristas da Bahia, recebeu em sua academia a visita de um pintor angolano, que afirmava ter visto, em África, uma dança que se assemelhava com a capoeira que o mestre ensinava, porém afirmava que em África essa dança se chamava n'golo. Descrição de Albano Neves ao mestre Pastinha:

O n,golo, explicou Neves e Souza ao velho capoeirista, é dançado por rapazes nos territórios do sul de Angola durante o ritual da puberdade das meninas. Chamado de mufico, efico ou efundula, esse ritual marca a passagem da moça para a condição de mulher, apta a namorar, casar e ter filhos. É uma grande festa em que se consome muito macau, bebida feita de um cereal chamado massambala. O objetivo do n'golo é vencer o adversário atingindo seu rosto com o pé. A dança é marcada pelas palmas, e, como na roda de capoeira, não se pode pisar fora de uma área demarcada. N'golo significa "zebra", e, de fato, alguns movimentos- em particular o golpe dado pelo pé, de costas e com as duas mãos no chãoparecem mesmo com o coice de uma zebra (ASSUNÇÃO; COBRA MANSA, 2009, p. 64).

Como os autores apresentam neste estudo, esta revelação foi um fato novo para aqueles que se dedicavam a estudar as possíveis origens da capoeira. De fato os registros e argumentações que o pintor angolano, Albano Neves e Sousa, trazia sobre as semelhanças entre o n'golo e a capoeira eram convincentes, de modo que uma publicação de desenhos originais do artista plástico, no ano de 1972, revelavam essas semelhanças:

\begin{abstract}
Algumas imagens evidenciavam semelhanças surpreendentes entre a capoeira e o n'golo, como o uso de golpes com os pés, enquanto as mãos se apoiam no chão ( chamado na capoeira de "meia lua de compasso ou " rabo de arraia"), muito raro em outras artes marciais. Recentemente, surgiram mais evidências desse parentesco. A viúva de Albano revelou esboços e aquarelas inéditos [...] Eles mostram detalhes adicionais do n'golo: o apoio nos braços com uma perna dobrada e a outra esticada para dar um golpe, por exemplo, é idêntico à movimentação na capoeira. E a postura de defesa, com um joelho dobrado e outro esticado, é muito parecida com a "negativa" dos nossos capoeiristas. Como esses movimentos parecem existir somente em jogos de combate da diáspora dos povos bantos, permanece relevante o vínculo ancestral entre o n'golo e a capoeira brasileira (ASSUNÇÃO; COBRA MANSA, 2009, p. 66- 67).
\end{abstract}

As investidas de Albano Neves e outros intelectuais como o folclorista Luís da Câmara Cascudo (1898-1986), na ideia de que a dança da zebra, o n'golo, seria o ancestral da capoeira, contribuíram para criar na comunidade capoeirista aquilo que Mathias e o Mestre Cobra Mansa apontam em seus estudos, como o mito de origem da 
capoeira em uma "tradição ancestral", porém revelam que esse ponto é bem mais complexo, e acrescentam:

Talvez o mais correto seja imaginar o n'golo e as outras lutas e jogos de combate ainda existentes na Angola contemporânea como primos mais ou menos distantes da capoeira brasileira. Findo o tráfico negreiro, as técnicas de combate corporal, que existiam dos dois lados do Atlântico, teriam evoluído em direções diversas, o que explicaria não só suas semelhanças, mas também suas tremendas diferenças (ASSUNÇÃO; COBRA MANSA, 2009, p. 68).

Ao longo dos tempos foram levantas muitas hipóteses sobre o surgimento da capoeira, muitos afirmavam que essa manifestação teria se iniciado nas senzalas e que suas características de dança e luta, eram fruto de uma dissimulação para que os senhores de escravos não percebessem que os negros estavam buscando formas de se empoderar através de elementos próprios da sua cultura. Também existem relatos de que a capoeira teria surgido nas regiões de fuga e resistência dos escravos, os quilombos, mais especificamente no quilombo de Palmares. Suposições não descartáveis, porém ainda difíceis de constatar.

Um dos fatores que dificulta a reconstrução histórica da capoeira para antes do séc XIX, é a carência de documentos e registros sobre períodos mais remotos do Brasil escravista. Este fato pode ter muitas explicações, uma delas se deve à iniciativa de Rui Barbosa, quando ministro da fazenda, ter determinado a destruição de documentos referentes à escravidão. Os autores da obra $O$ mestre de capoeira angola ensina pegando pela mão: saberes, artefatos e rituais no processo de formação (SILVA [et al], 2011) trouxeram os estudos de Waldeloir Rego de 1968 em que, ao abordar a questão do mau serviço prestado por Rui Barbosa, faz menção a uma declaração do ex-ministro da fazenda alegando que a nação brasileira, por sublime evolução histórica, teria eliminado do solo da pátria a escravidão. Desse modo, a República estaria obrigada a destruir estes vestígios por honra da pátria, além de que seria este um gesto de fraternidade e solidariedade para com os ex-escravos que, a partir da abolição, passavam a fazer parte da comunhão brasileira.

Ainda nesses estudos, podemos encontrar a citação presente nos textos de Waldeloir Rego sobre a resolução de 15 de dezembro de 1890, elaborada para respaldar a retirada dos documentos que existiam no Ministério da Fazenda sobre os registros dos escravos: 
$1^{\circ}$ - Serão requisitados de todas as tesourarias da Fazenda todos os papéis, livros e documentos existentes das repartições do Ministério da Fazenda, relativos ao elemento servil, matrícula de escravos, dos ingênuos, filhos livres de mulher escrava e libertos sexagenários, que deverão ser sem demora remetidos a esta capital e reunidos em lugar apropriado na recebedoria.

$2^{\circ}$ - Uma comissão composta dos Srs. João Fernandes Clapp, presidente da comissão abolicionista, e do administrador da recebedoria desta capital, dirigirá a arrecadação dos referidos livros e papéis e procederá a queima e destruição imediata deles, o que se fará na casa de máquina da alfândega, desta capital, pelo modo que mais conveniente parecer à comissão. Capital Federal, 15 dezembro de 1890 - Rui Barbosa (SILVA [et al], 2011, p. 17).

A iniciativa do ex-ministro da Fazenda em "varrer a sujeira para debaixo do tapete", pouco reverberou em uma mudança de consciência sobre o lugar dos negros na sociedade brasileira. No ano de 1890, o Código Penal da República dos Estados Unidos do Brasil, reconhece a capoeira como uma legítima manifestação de marginais. Anos antes, a repressão que sofria a capoeira e as diversas manifestações dos povos africanos no Brasil à exemplo dos terreiros de candomblé, revela o espaço destinado aos negros na nossa sociedade. Tanto o candomblé como a capoeira "foram violentamente perseguidos por representarem espaços de resistência, na medida em que trabalharam a consciência física, mental e espiritual dos africanos e seus descendentes desde o século XIX, pelo menos" (BARRETO, 2005, p. 22).

Neste mesmo século, antes mesmo da proclamação da república e criminalização da capoeira, no ambiente urbano do Rio de Janeiro, os escravos se organizavam em grupos de resistência ao sistema escravista, que tinham a capoeira como principal arma de luta. Os escravos de ganho que saíam do ambiente rural para a cidade enfrentavam inúmeras adversidades, principalmente com a polícia. As prisões de escravos era rotineira e o terror vivenciado pela elite e pelas instituições da ordem, diga-se de passagem o Estado e a Polícia, tinha um oponente estrategista e sagaz: o capoeira.

Os capoeiras se organizavam em maltas, estas eram grupos que se uniam não só para o jogo da capoeiragem, como também para se fortalecerem diante das injustiças do sistema escravocrata. De acordo com Carlos Eugênio Líbano Soares (2004), já por volta de 1810 é possível constatar a prisão de escravos “ jogando capoeira”(p.74), de modo que não era fácil distinguir onde terminava a luta e se iniciava a brincadeira. As praças abertas eram locais preferidos dos capoeiras, não apenas pela amplitude de espaço, mas 
também pelas facilidades de fuga que proporcionavam. Os grupos costumavam ser pequenos e se distribuíam por vários pontos da cidade, em diversas praças. Isso dificultava a desarticulação das maltas, que no decorrer dos anos " pipocavam" cada vez mais na cidade do Rio de janeiro.

Como destaca este mesmo estudioso, o capoeira era um tipo social,

figura de destaque dentro da comunidade escrava na cidade, não apenas por suas habilidades marciais, mas pelas qualidades de companheirismo e liderança, que já faziam parte integrante dos modos de agir daqueles praticantes. Seu prestígio também pode estar ligado, em alguns casos, a conhecimentos mágico-religiosos e ao consequente exercício destas práticas, altamente relevantes para a massa escrava. A desenvoltura com que eles se moviam pela cidade facilitava estas práticas.( SOARES, 2004, p. 75-76).

Os escravos eram submetidos a inúmeras demonstrações de brutalidade que dilaceravam a comunidade escrava, facilitando a dominação do homem branco e criando um ambiente de reação e violência:

Por volta da década de 1810, a capoeira já era uma fixação para os jovens escravos africanos, na cidade, e seu desafio à ordem escravista era semelhante a uma guerra de guerrilha, com surtidas isoladas, inesperadas, imprevisíveis, realizadas por pequenos grupos que, prontamente, dispersavam-se ao menor sinal dos agentes da ordem (SOARES, 2004, p.77)

O jogo da capoeira era muito mais que uma briga de rua, era um jogo de corpo sofisticado, e o capoeira conhecia bem as condições com as quais precisava lidar. A partir de 1812, duzentos açoites eram o castigo médio sofrido no Calabouço:

Os motivos pelos quais escravos eram levados para o Calabouço eram os mais variados e fúteis: " fora de horas", "suspeito", "atitude estranha", ou simplesmente estar parado nas esquinas era motivo suficiente para o negro ser detido, (...) Qualquer atividade estranha, incomum, insólita, era o bastante para levar o indivíduo para a prisão, o que apontava para o medo que as autoridades tinham da riqueza cultural africana na cidade, e como estes " folguedos" podiam significar atos de autonomia e mesmo de rebelião no ambiente congestionado da cidade ( Idem, Ibidem, p. 79- 82)

As manifestações dos povos africanos eram reprimidas em diversos pontos da colônia, e no que tange à capoeira havia modalidades distintas de sua manifestação “ em cada grande cidade portuária do Brasil: Belém, São Luís, Recife, Salvador e Rio de Janeiro.” ( ASSUNÇÃO; COBRA MANSA, 2009, p. 69). Após a Proclamação da República, a capoeira se torna um crime previsto no Código Penal. Este quadro se estende até meados do séc XX. “Durante a maior parte do século XIX até as três primeiras décadas do século $\mathrm{XX}$, a capoeira sempre esteve associada ao mundo do 
crime. Poucas vezes ela foi compreendida como uma prática cultural pertinente à sociedade brasileira" ( LEAL; OLIVEIRA, 2009, p. 48).

\subsection{Na luta por existir: a capoeira angola}

No ano de 1937, a capoeira sai das páginas do Código Penal e deixa de ser tratada como um crime, este fato não implica em seu reconhecimento como manifestação cultural. A descriminalização da capoeira, embora tenha representado um passo ante sua repressão, pouco representou em termos de mudança na mentalidade brasileira em relação às expressões da cultura popular afro-brasileira. Ainda por esses tempos a capoeira e todos aqueles que estavam envolvidos em seu contexto estavam à margem da sociedade, logo a capoeira era uma prática de marginais. Negros forros, imigrantes, trabalhadores e trabalhadoras, prostitutas, quitandeiras e diversas personalidades marginalizadas da camada popular estavam envolvidos no contexto da capoeiragem ( LEAL; OLIVEIRA, 2009).

O reconhecimento da capoeira como manifestação da cultura popular afrobrasileira, perpassa por caminhos de luta, sendo seus principais atores os mestres, mestras, discípulos da capoeira e intelectuais engajados na legitimidade da cultura negra, sendo que no mesmo ano em que a capoeira é descriminalizada

ocorreu em Salvador o II Congresso Afro-brasileiro organizado por diversos intelectuais, preocupados com o estudo da cultura negra no Brasil, a exemplo de Edison Carneiro e Jorge Amado, assim como lideranças do candomblé, na capital baiana. Nesse congresso, os diferentes representantes de práticas culturais afro-brasileiras foram convidados a se pronunciar, ampliando o diálogo entre os estudiosos e os agentes das manifestações de matriz africana( LEAL; OLIVEIRA, 2009, p. 22).

Antes mesmo da descriminalização, Manoel dos Reis Machado (1900-1974), mestre Bimba, inicia o processo de organização da capoeira em uma escola ao criar o Centro de Cultura Física e Regional da Bahia, onde ensinava a Luta Regional Baiana, popularmente conhecida como capoeira regional. Nos estudos realizados na obra $O$ mestre de capoeira angola ensina pegando pela mão: saberes, artefatos e rituais no processo de formação (SILVA [et al], 2009), podemos destacar as principais motivações de mestre Bimba para a criação da capoeira regional. Ao analisarem uma entrevista que o mestre concedeu ao etnólogo Waldeloir Rego, os autores destacam que a capoeira 
tradicional era percebida por mestre Bimba como um fraco divertimento, ineficiente prática de educação física, defesa e ataque pessoal, e para que a capoeira se tornasse mais efetiva, incorporou em sua prática golpes de batuque, detalhes da coreografia do maculelê, de folguedos, além de golpes de luta greco-romana, jiu-jítsu, judô e a savate.

Outro ponto importante da iniciativa do mestre Bimba, foi a busca pelo reconhecimento e visibilidade da capoeira, na tentativa de elevar seu status se apropriando de elementos da educação formal. Assim como explicita José Luiz Sirqueira Falcão (1996), a criação da capoeira regional garante ao mestre Bimba, a conquista de autoridades e profissionais liberais. Essa conquista é garantida e mantida com o ensino da capoeira em recintos fechados, como o das academias, que no caso da capoeira regional, eram frequentadas principalmente por pessoas das camadas sociais superiores. O lócus da capoeira não era mais exclusivamente as ruas e os terreiros. Com a capoeira regional, foram estabelecidos os primeiros contatos com as instituições escolares, inclusive com o meio universitário, já que muitos acadêmicos, buscavam o senhor Bimba como mestre de capoeira.

Os novos códigos incorporados à capoeira regional a aproximavam das práticas de educação formal, com a metodização de um sistema de sequências de movimentos de capoeira e a criação de uma série de procedimentos didáticos, tais como, exame de admissão, curso de especialização, cerimônias de batismo e graduação, sistema de hierarquia com graduações e formaturas (FALCÃO, 2004). A capoeira regional foi amplamente difundida pelo Brasil como uma modalidade de luta, com destaque para o combate, a competição, a velocidade dos movimentos, a eficiência dos mesmos à partir de golpes de impacto e com uma ênfase maior no espetáculo e não na teatralização.

No período histórico em que sucedeu a criação da capoeira regional, o Brasil atravessava o Estado Novo da Era Vargas. Uma das principais demandas desse período era estabelecer um imaginário de identidade nacional, através de manifestações da nossa cultura que garantissem o sentimento patriótico de brasilidade, em consonância com um processo mundial de guerras que tinham como marco o acirramento dos nacionalismos. "A mestiçagem- inferno racial da geração de 1870- é cantada em prosa e verso na nova "raça brasileira" inventada pelo getulismo" (SOARES, 2009, p.18). E deste mesmo período podemos citar ainda a informação presente nos estudos da obra Capoeira, identidade e gênero: ensaios sobre a história social da capoeira no Brasil 2009 de que no ano de 1937, o mestre Bimba realiza uma apresentação de capoeira regional, na 
Bahia, para Getúlio Vargas. Neste sentido, a criação da capoeira regional e os projetos políticos indenitários do getulismo são fatores que convergem na construção de um imaginário de cultura brasileira, em que a capoeira era a representação do esporte nacional por excelência.

A iniciativa do mestre Bimba com a criação da capoeira regional, em suas diversas nuances, representava também uma busca por existir diante de um sistema que não conferia créditos às manifestações da cultura popular afro-brasileira. Talvez, a intersecção entre a capoeira, as instituições e personalidades legitimadas pela sociedade, fosse percebida por mestre Bimba como a via mais sustentável de manifestação da capoeira. Porém havia uma comunidade de capoeiristas que se engajariam nessa mesma batalha por legitimidade, por meio da salvaguarda dos elementos fundamentais da capoeira na manifestação da arte-luta que passaria a ser denominada capoeira angola.

A luta por visibilidade e legitimidade foi um processo vivenciado por diversos personagens envolvidos no universo da capoeiragem. Foram várias frentes de demanda, sendo que em consonância com os estudos do pesquisador Paulo Magalhães (2012) podemos destacar "três momentos fundamentais de organização política da comunidade angoleira deste momento - as lutas de ringue, o Congresso Afro-Brasileiro e a criação do Centro de Capoeira Angola” (p. 72).

Os estudos de Paulo Magalhães (2012), publicados na obra Jogo de discursos: a disputa por hegemonia na tradição da capoeira angola, são em muitos sentidos reveladores, por uma abordagem de onde emergem as contradições e complexidades dos fenômenos que envolvem a capoeira. De acordo com este estudo as lutas de ringue que já existiam em algumas regiões brasileiras desde o início do séc XX, foram marcantes para definir caminhos de legitimidade das práticas culturais da capoeira. Essas lutas, assim como sinaliza Paulo Magalhães abarcavam atletas do boxe, jiu-jitsu, catch-ascatch, capoeira regional e capoeira angola. Havia uma busca pelo reconhecimento da capoeira enquanto esporte, e muitas rivalidades entre as duas manifestações da capoeira já se manifestavam aqui, porém isso não significa que não havia também sob alguns aspectos, o relacionamento amistoso entre personalidades integrantes tanto da capoeira regional, quanto da capoeira angola.

Como já citamos em outro momento deste texto, o mestre Bimba, acreditava que a capoeira angola era uma modalidade de luta ineficiente, desse modo ao inserir aspectos de outras lutas na sua capoeiragem, se adequava bem às regras das lutas de 
ringue que em contraponto eram questionadas pelos angoleiros. "Os representantes da angola e da regional, embora vissem nas competições uma forma de ascensão da capoeira e de seus praticantes, tinham opiniões fortemente divergentes em relação às regras da competição.” (MAGALHÃES, 2012, p.60). De acordo com o citado autor os debates em torno dessas regras demonstravam uma disputa implícita pela legitimidade de diferentes projetos políticos-identitários, nesse sentido acrescenta:

Enquanto os angoleiros buscavam regras que não retirassem da capoeira seus aspectos rítmicos, lúdicos e simbólicos, Bimba propunha que os conhecimentos de capoeira servissem para uma luta livre, " à vera", com proibição apenas de dedo nos olhos, pancada nos órgãos genitais, dentada e puxamento de cabelos.(...) É verdade que tanto os angoleiros quanto os regionais buscaram novos caminhos para legitimar suas práticas, dialogando com o modelo dominante no campo dos esportes, (...), entretanto, a diferença significativa que se afirma neste momento: enquanto Bimba aceita as regras do jogo, equiparando sua luta regional baiana a quaisquer outras lutas, os angoleiros insistem no caráter diferenciado da capoeira angola, que não prescinde do seu ritual e musicalidade ( Idem, Ibidem, p. 60-63).

Neste sentido, podemos perceber que a comunidade angoleira, em sua luta pela resistência ante a cultura hegemônica, tinha como busca a conservação da sua totalidade, em diálogo com outras totalidades que constroem a nossa realidade. Como afirma Paulo Magalhães (2012): "Esta é marca distintiva da capoeira angola - não ousaríamos ainda dizer a fidelidade à tradição, mas a construção de uma identidade que usa a tradição como uma importante base, ancorada em um discurso de preservação da mesma" (p.65).

O processo de organização da comunidade angoleira, contou com a participação de outras personalidades da sociedade brasileira, como por exemplo, a intelectualidade engajada na legitimação das manifestações da cultura afro-brasileira. Este fato se mostrou evidente no já citado, II Congresso Afro-Brasileiro na Bahia, coordenado por Édison Carneiro. Dentre as pautas do evento havia a União dos Capoeiras da Bahia, sendo que os angoleiros eram aqueles que estavam exclusivamente envolvidos nessa demanda. Neste engajamento político podemos citar importantes figuras tais como: "Samuel Querino de Deus, o capitão Aberrê, Bugaia, Onça Preta, Barbosa, Zepelim, Juvenal e Polú". ( MAGALHÃES, 2012, p.65)

Além dos citados capoeiras, outros mais deveriam estar envolvidos nesse processo de organização e resistência que de acordo com Paulo Magalhães (2012), culminaria na criação do Centro de Capoeira Angola. Talvez seja esse o gérmen de um 
fato que anos mais tarde, marcou a trajetória da capoeira: a organização do Centro Esportivo de Capoeira Angola coordenado por Vicente Ferreira Pastinha, o mestre Pastinha. Vale ressaltar novamente que diversos capoeiras estavam envolvidos neste processo, como por exemplo, os mestres Noronha e Raimundo Aberrê. A comunidade angoleira ansiava por reconhecimento e dignidade na manifestação da capoeiragem, dialogando com o novo sem molestar as raízes como bem aponta o mestre Pato.

O mestre Pastinha cumpria vários requisitos enquanto representante da comunidade angoleira no diálogo com as instituições formais, como por exemplo o fato de que o mestre era um dos poucos capoeiras, que naquele período possuía o domínio da leitura e escrita do idioma socialmente legítimo: "Em um universo de iletrados, Pastinha era um dos poucos que sabia escrever bem, tendo condições de ser um mediador que articulasse a capoeiragem tradicional com outros setores da sociedade, a fim de garantir a aceitação e ascensão dessa prática cultural”.( MAGALHÃES, 2012, p. 74)

A criação do Centro Esportivo de Capoeira Angola (CECA), inaugurou um outro momento no universo da capoeira, sendo que a vertente angola representava inúmeras transformações na arte-luta, com um norte bem definido pelos angoleiros: a preservação da musicalidade, corporeidade, filosofia e fundamentos da capoeira tradicional. Além do CECA podemos destacar outros ambiente de ensino e aprendizagem da capoeira angola, como por exemplo, o Barracão do mestre Waldemar.

A luta dos angoleiros pelo direito de se manifestarem de forma legítima por meio da sua arte prevalece ainda hoje como importante pauta no universo da capoeira angola. Revela ainda um direcionamento político pela manifestação digna e autônoma de uma manifestação da cultura popular afro-brasileira, que se constitui como um saber com processos de ensino e aprendizagem muitas vezes incompreendidos pelas esferas formais e hegemônicas de transmissão do conhecimento. Aprofundemos nesta questão mais à diante. 


\title{
CAPÍTULO 3 - A CAPOEIRA ANGOLA: UMA ESCOLA DE CAPOEIRA
}

\author{
Canjiquinha é do tempo. \\ É do tempo em que capoeira, filosofia e putaria \\ são aprendidas na rua. A rua "habitat dos \\ grandes problemas", popularmente \\ universalizada como escola onde se aprende \\ truques, macetes, malandragem, arte e \\ artimanhas - ensinamentos espertos. A \\ cartilagem que não nos deixa cair. Bater a \\ bunda no chão quando a vida, no seu curso, \\ fuzila situações novas e inesperadas, golpes \\ baixos, jogo sujo, traiçoeiragem \\ (GAFANHOTO [et al], 1989, p. 3).
}

As principais fontes de estudo sobre a capoeira, costumam retratar a sua trajetória e a dos capoeiras no momento em que ela se manifesta nas principais cidades portuárias do Brasil escravocrata. Antes da criação do Centro Esportivo de Capoeira Angola ou da existência de espaços como o Barracão do mestre Waldemar, o ambiente primordial de aprendizagem da capoeira era a rua, o lugar do acaso e das interações imprevistas. O boteco, a esquina, a praça, a feira, a sombra das árvores, a beira do mar, o cais.

A rua dos assobios e da resistência ao sistema escravocrata era também o ambiente de aprendizagem da sobrevivência. Os pontos dos encontros de pessoas diversas, por inúmeras motivações traziam consigo os contextos de vida daqueles que nos comércios e interações, trocavam acima de tudo as suas contradições. A escravidão era uma pergunta, a liberdade uma resposta. A capoeira trazia uma das letras.

Quem aprendia capoeira, aprendia também a mandinga para lidar com as inúmeras adversidades impostas pelo sistema. $\mathrm{O}$ aprendizado acontecia em tempo vivo, na escola da rua por meio da oitiva. Nos relatos de muitos capoeiras antigos, costumamos encontrar algumas referências sobre a oitiva. Não foram poucos aqueles que antes de receberem os ensinamentos da capoeira de algum mestre, passaram um bom tempo somente observando as rodas e como os capoeiras jogavam. Há um fato interessante na formação do mestre Canjiquinha que ilustra este ponto. $\mathrm{O}$ mestre conta em um texto autobiográfico como iniciou o aprendizado da capoeira com o mestre Aberrê:

Eu era menino. Tinha lá uma baixada chamada Matatu Pequeno, um morro no bairro Matatu e lá em baixo tinha um largo, um terreiro. Lá 
aos domingos, vinham todos aqueles capoeiristas (...) e esse cidadão chamado Antonio Raimundo, apelidado por todos Aberrê. Todo domingo eu ia lá olhar, até que um dia ele me chamou e disse: “Meu fio, venha cá, cê qué aprendê capoeira?" Eu disse: quero. Então ele mandou eu me abaixar e vupt, deu um chute. Eu depressa deu um pulo prá traz e ele: "óia, meu fio, a partir de hoje vô lhe ensiná" (CANJIQUINHA, 1986, p. 28).

8 anos depois...O mestre disse assim:

- É o seguinte meu filho você corre esse lugar aí o que você vê e gostar, você fica prá você.Se não gostar deixa prá lá.Então eu ia olhando os capoeiras. Eu jogava, perguntava ao finado Geraldo Chapeleiro.Eu perguntava as coisas e ele me explicava.Ele via meu interesse, me explicava.E gente mais me ensinou.A tocar berimbau foi Zeca do Uruguai.Eu todo domingo levava charuto prá ele.Então ele me ensinava a tocar berimbau (GAFANHOTO, 1989, p. 12).

Ainda hoje a oitiva é valorizada por mestres e mestras como uma das formas de se aprender a capoeira, até mesmo porque aprender a observar é imprescindível para o capoeira. Conforme o pesquisador Pedro Abib (2005) "A oitiva constitui-se como um claro exemplo de como se dá a transmissão através da oralidade na capoeira, baseada na experiência e na observação" (p.178). Além da oitiva Pedro Abib, mediante depoimentos do mestre Moraes, revela que uma outra forma de aprendizado da capoeira, poderia acontecer individualmente nos quintais e terreiros das casas, onde havia uma relação íntima entre mestre e aprendiz.

Isso acontecia também porque muitas vezes o aprendiz de capoeira era aprendiz de ofício do mestre que comumente poderia ser um marceneiro, sapateiro, ferreiro ou artesão. "A convivência entre mestre e aprendiz era então um fator que auxiliava muito o processo de aprendizagem da capoeira" (ABIB, 2005, p. 179). É possível ilustrar este fato também nas palavras de Moacir Gadotti:

“ Um mestre vivia- filósofo ou ferreiro, por exemplo; seus colegas e seus aprendizes viviam com ele; eles aprendiam o que lhes ensinava de trabalho manual ou intelectual, mas aprendiam também sem se aperceber, nem eles nem ele; aprendiam sem se aperceber o mistério da vida na pessoa; o Espírito os visitava. Coisas semelhantes veêm-se ainda, em certa medida, ali onde há espírito e pessoa; mas elas são confinadas aos limites da espiritualidade e da personalidade, eles tornam-se exceção, “ altitude”. (GADOTTI, 2003, p. 166 )

Dentre os movimentos de resistência da capoeira, foram criados por parte da comunidade angoleira diversos ambientes de ensino e aprendizagem da arte, essa iniciativa alargou as possibilidades de transmissão dos saberes da capoeira. Na Bahia, como cita Pedro Abib (2005) havia espaços tais como as rodas da Gengibirra, o 
Barracão do mestre Waldemar e o Centro de Capoeira Angola coordenado por mestre Pastinha; estes primavam pela tradição da capoeira, voltada para a " vadiação", para a brincadeira e mesmo enquanto luta. Todo domingo era dia de vadiação no Barracão do mestre Waldemar, no bairro da Liberdade em Salvador-Bahia. De acordo com Pedro Abib(2005):

A escola do mestre Pastinha, por sua vez, funcionou por último na
Ladeira do Pelourinho, durante várias décadas até quase a sua morte
em 1980, era também um dos locais de maior referência do ensino e
da prática da capoeira angola. As rodas que lá aconteciam levavam
muitos visitantes, interessados em apreciar as exibições dos grandes
capoeiras da época. Seus alunos mais famosos - João Pequeno e João
Grande - tornaram-se as maiores referências da capoeira angola da
atualidade, justamente pelo estilo "clássico" que caracteriza o jogo dos
dois, hoje responsáveis pela manutenção do legado do mestre
Pastinha, através da continuidade da forma tradicional de ensinar e
praticar a capoeira angola que persiste em suas escolas. (p. 151)

Foram criadas escolas de capoeira angola e juntamente com elas um universo de experimentação da capoeira que tinha como base a dimensão filosófica da capoeiragem antiga, mas que assumia outras estruturas ritualísticas de ensino e aprendizagem, como a criação de espaços fechados, com horários definidos para a prática do ensino e aprendizagem. O uso de uniformes e sapatos, a reorganização da bateria em oito instrumentos básicos: três berimbaus- gunga, médio e viola, dois pandeiros, agogô, reco-reco e atabaque. Além do caxixi, portanto de fato nove instrumentos básicos.

A capoeira angola é uma manifestação da cultura popular afro-brasileira brasileira que se apresenta através de uma corporeidade e musicalidade embebidas em poesia, ritual e fundamento. É um sistema vivencial de transmissão de saberes e valores, que de acordo com Pedro Abib (2002), possui em seu universo elementos e conhecimentos que caracterizam um processo de educação baseados nos saberes e nas tradições populares. Em obra intitulada, Capoeira Angola: cultura popular e o jogo de saberes na roda, Pedro Abib (2005), aborda os saberes e aprendizados presentes no ritual de passagem da roda de capoeira angola, em uma trajetória discursiva que elenca três elementos fundamentais do universo de transmissão de saberes da cultura popular: a memória, a oralidade e a ritualidade. Em suas análises, o autor, percebe como a capoeira angola enquanto manifestação da cultura popular trás uma lógica de transmissão de saber diferenciada dos moldes racionalistas de aprendizado, por carregar a mitologia ancestral e os saberes tradicionais do grupo. 
De acordo com o citado autor, a memória, no universo da cultura popular e mais especificamente na capoeira angola, representa o trabalho de reconstrução coletiva de um passado que continua presente, fortalecendo os vínculos de relacionamento de um grupo. Longe de um passado nostálgico, a memória revitaliza os tempos remotos no presente por meio da oralidade. Nessa forma de transmissão de saber, há uma figura fundamental: o mestre. Aqui acrescentamos a mestra. Nas palavras de Pedro Abib ( 2005):

\begin{abstract}
Essa figura é fundamental no seio de uma cultura na qual a transmissão do saber passa pela via da oralidade, e por isso depende desses guardiões da memória coletiva para que esta seja preservada e oferecida às novas gerações. O mestre é aquele que é reconhecido por sua comunidade, como detentor de um saber que encarna as lutas e sofrimentos, alegrias e celebrações, derrotas e vitórias, orgulho e heroísmo das gerações passadas, e tem a missão quase religiosa, de disponibilizar esse saber àqueles que a ele recorrem. $\mathrm{O}$ mestre corporifica, assim, a ancestralidade e a história de seu povo e assume por essa razão, a função do poeta que, através do seu canto, é capaz de restituir esse passado como força instauradora que irrompe para dignificar o presente, e conduzir a ação construtiva do futuro. (p. 95)
\end{abstract}

Desse modo, os mestres e mestras tem sua autoridade e saberes reconhecidos na prática cotidiana, do saber fazer. Empoderados via experiência de vida, são reconhecidos por terem o domínio de todos os aspectos da arte, desde a confecção dos seus artefatos até a incorporação da filosofia que fundamenta a capoeira. Transmitem saberes e sabedoria por meio da oralidade manifesta também nas músicas e ladainhas da capoeira. Compreendemos aqui a autoridade como um poder imbuído de legitimidade, conquistada por merecimento e não o simples mando (SENNET, 2012), no caso da capoeira angola a autoridade das mestras e mestres é conquistada pelo conhecimento profundo da arte adquirida na experiência cotidiana.

Na capoeira angola, não há sistemas de classificação do saber representado em gradações de conhecimento adquiridas por meio de testes e aprovações. Para além disso, seu aprendizado se configura por meio de ritos de passagem, onde a roda de capoeira é o principal espaço vivencial de iniciação. A ritualidade, segundo Pedro Abib (2005) é o processo de iniciação, que tem seus preceitos e tradições guardados pelo mestre, possibilitando sua continuidade no tempo também através do mistério e magia como componentes fundamentais do rito. $\mathrm{O}$ ritual permite a conexão com o sagrado, sendo fonte que continuamente suscita os sentidos. 
A relevância dos mestres e mestras no universo da capoeira angola the garante uma das suas principais característica, que é a ancestralidade. A capoeira é um saber de matriz africana, e assim como os grandes mistérios da vida não possui uma origem revelada. Porém já sabemos que boa parte do que ela carrega está fundamentado numa sabedoria que "vem de longe".

A ancestralidade tem como uma das suas bases, o respeito aos mais velhos enquanto seres humanos que em sua face carregam as marcas de um tempo que no pergaminho da pele estão o sol, a lua, as intempéries, alegrias, tristezas, experiências de vida. Compreensões sagradas, transmitidas dos mais velhos aos mais novos. Na maioria das vezes inspiradas nos ensinamentos daqueles que já se foram. Cosmovisão ancestral, em um saber que de geração à geração se configura por um sistema de linhagens, sistema este que " funciona como uma espécie de pedigree, uma marca de origem que atesta a herança e tradicionalismo do mestre" ( MAGALHÃES, 2012, p. 42)

Por mais que a comunidade capoeirista compartilhe de códigos comuns, há peculiaridades que variam de uma linhagem a outra. Também sendo cada ser humano um universo, cada mestra e cada mestre de capoeira vem com uma proposta específica de transmissão do saber, dentro dos limites dos fundamentos e filosofia da capoeira. Nesse sentido, os grupos de capoeira angola, são considerados hoje verdadeiros ambientes de ensino e aprendizagem de uma filosofia de vida que se aprende principalmente através do corpo, em comunidade e de forma espelhada, com os outros.

O aprendizado da corporeidade e musicalidade da capoeira preparam o aprendiz para o jogo, para a vadiação. A vadiação é o jogo brincado, o diálogo mandingado, onde não está em questão a possibilidade de vitoriosos e subjugados. Há perguntas e respostas, fundamentadas em um enigma cósmico indissolúvel por meio da competição. Nas palavras do velho mestre Pastinha(2013):

Amigo não fique descunfiado

O que eu fasso brincando

Você só faz é zangado

Você é vaidoso

E é despeitado

Na capoeira

Você ficou disclaficado ( p. 5) 
Nesse sentido a vadiação é vivida por meio de movimentos que a todo momento desafiam os limites do corpo humano. Equilíbrio, mudança de eixo, atenção, perspicácia, destreza e tranquilidade. O jogo da capoeira exige a nossa presença como um todo. De acordo com Mestre Bola Sete (1997) não é possível mensurar quantos sejam os movimentos de capoeira, pois esta é um jogo livre, com possibilidades de improviso e de criação de novos movimentos no momento do jogo, mas existem movimentações básicas de onde tudo pode ressurgir. Nas palavras da capoeira e pesquisadora Sara Abreu da Mata Machado (2011):

Aprender os movimentos da capoeira não se limita a aprender a jogar em uma roda de capoeira. Movimentar o corpo de forma " ancestral" volta-se, por exemplo, às possibilidades de movimentos mais voltados à nossa condição de seres da natureza, como os movimentos dos animais. Como se fosse uma redescoberta de nossas possibilidades, quase esquecidas no curso da história da humanidade e da dita civilização - ereta, racional, social, sedentária, urbana. Movimentar o corpo, na vida, com a capoeira, é fugir do plano cartesiano e explorar a diversidade das formas naturais, ancestrais, onde a floresta, o mar, o rio, as montanhas, os animais, o ar, estamos todos conectados, como partes de um ser vivo maior, que é o planeta Terra e, mais ainda, o Universo (p. 14).

A musicalidade da capoeira angola se expressa na energia da bateria e dos cantos embebidos de poética, historia e vida. Berimbau, caxixi, pandeiro, reco-reco, agogô e atabaque, são responsáveis por criar a atmosfera cósmica para o canto da ladainha, da louvação e em seguida dos corridos. Os capoeiras costumam cantar e ouvir os cantos de acordo com o desenrolar da roda de capoeira, neste ritual circular que é o momento mais íntimo de encontro do capoeira com a ancestralidade. É o momento em que o capoeira aprende na pequena roda, como vivenciar a grande roda da vida.

Os fundamentos da capoeira angola são o conjunto de regras, valores, tradições e códigos, que ganham densidade na vivencia estética da capoeira, de forma que ser capoeira é tentar levar uma vida orientada por valores de comunidade, respeito, humanidade, liberdade, cuidado e muitos outros que direcionam o comportamento dos angoleiros. De acordo com Cláudia Pato (2011), os valores são objetivos abstratos que estão para além das situações e ações específicas. São a nossa orientação na seleção ou avaliação de comportamentos. Servem como padrões para tomarmos decisões. Assim, podemos perceber a capoeira angola como uma escola de vida, na qual não se aprende apenas a jogar capoeira, mas também a jogar na roda do mundo, a tomar posição, analisar circunstâncias de classes sociais com interesses antagônicos, interferir no 
sentido de querer transformar a realidade. E é nesse sentido que podemos perceber o potencial transformador desse saber, que nos permite gingar com um mundo em processos de profunda mudança como se cada dia fosse uma vadiação, que nos garante elementos não apenas para dialogar, como também aos poucos assimilar o grande aprendizado de viver no tempo.

Para aprofundar o nosso olhar sobre os aspectos formativos da capoeira angola, partimos do princípio das especificidades que há em cada grupo de capoeira, por isso buscamos refletir sobre esses aspectos no ambiente do grupo nZambi de capoeira angola. Para cumprir com esse objetivo iniciamos traçando a trajetória de formação deste grupo, até o momento em que é criado um núcleo de trabalho em Florianópolis Santa Catarina. Serão cenas dos próximos capítulos. 


\section{CAPÍTULO 4 - METODOLOGIA}

\section{AS ENCRUZILHADAS DE UM ESTUDO: LUGARES E CAMINHOS DA DESCOBERTA}

\subsection{A experiência estética de um encontro}

Este trabalho que dentre outros objetivos busca refletir sobre a capoeira angola e suas manifestações enquanto saber é fruto de um processo de libertação e envolvimento que se iniciou na infância. Em Paracatu, há alguns anos quando ainda pequena cidade do interior de Minas Gerais, aos domingos, por volta das seis da tarde tinha roda de capoeira na praça da cidade.

Aos quinzes anos de idade iniciei a prática da capoeira regional, única modalidade da arte na cidade de Paracatu. Foi um momento de intenso trabalho corporal envolvido em energia, alegria e socialização. Ainda hoje guardo no coração as amizades que se formaram no grupo de capoeira do qual fazia parte. Também não me esqueço dos nós e amarras que a capoeira me ajudou a desatar.

No ano de 2011 conheci o grupo nZambi de capoeira angola. Esse encontro foi motivado pelo convite de um camarada para conhecer os trabalhos desse grupo. Fui me integrando aos poucos, motivada pelos aprendizados que chegavam a mim por meio das aulas e das rodas de capoeira. Me sentia estimulada a fazer parte do grupo nZambi, pela possibilidade de estar em contato com algo que mesmo sendo parte da minha vida, se apresentava totalmente novo. Agora a capoeira chegava a mim com outros fundamentos, outros valores e outra filosofia. Além disso, havia um ponto que tornava o grupo nZambi uma experiência de inovação no universo da capoeira: era um dos poucos grupos de capoeira angola coordenado por uma mulher. Aqui no caso, a maranhense Elma Silva Weba, a mestra Elma.

Senti que o grupo nZambi era o local onde poderia vivenciar outros encontros com a capoeira, e desde então estender o olhar aos ângulos de experiência ainda pouco observados. A capoeira angola se tornava cada dia mais uma escola de vida e as “experiências estéticas” (PEREIRA, 2011, p. 227) advindas da sua prática objeto de pesquisa de onde emergiam jogos transformadores. Segundo a estudiosa Rita Marisa Ribes Pereira (2011), a pesquisa como uma experiência estética é aquela em que a 
pessoa que estuda está engajada com aquilo que observa de tal forma que este ato se torna um processo de acabamento do objeto e também de si mesmo. A dinâmica de pesquisa é aquela em que à medida que se expandem os ângulos de observação, quem realiza a pesquisa também se torna outra pessoa diante do processo. Complementando o pensamento da autora:

Experiência semelhante é a do pesquisador que dá a si mesmo acabamento à medida que desenha e redesenha seu objeto de estudo. Se, por um lado, o objeto exige do pesquisador a criação de um olhar que o perceba em sua inteireza, por outro, educa o olhar do pesquisador a perceber o mundo e a perceber-se no mundo de um modo inusitado (p.228).

Neste sentido, esse trabalho e também a redação deste texto, foram processos, experiências que se construíram diante de inúmeros ciclos de vida e morte, interpenetrados nas dores e alegrias de uma trajetória pulsante e artesanal. Cada escolha e cada etapa foram fruto de direcionamentos políticos e subjetivos que estiveram diante de vivências profundas. Este trabalho tem sal e suor. Certamente o tempo ainda está por trazer ao retorno muito do que foi vivido e ainda não assimilado. Como diz a mestra Elma: capoeira é tempo.

Nessa pesquisa, a capoeira angola norteia os rumos da prosa perfazendo uma caminhada em que a teoria emerge do objeto de estudo. A capoeira muito mais que um objeto, é uma experiência, um saber que desafia nosso olhar diante dos ecos que formam a vida. Desse modo, neste estudo, buscamos dar ouvidos a este saber não por meio de um monólogo e sim através de um jogo, partindo das coisas para as idéias (BOAVENTURA, 2010, p.26).

\subsection{Da nascente brotam os rios}

Uma figura de grande importância para os grupos de capoeira angola é a mestra ou o mestre do grupo, pois são figuras que exercem a função poética de protetores e guardiões da memória e tradição do seu povo (ABIB, 2005). No caso do nZambi, nossa mestra, a maranhense Elma Silva Weba, a mestra Elma, vive atualmente na Ilha de Florianópolis, onde desenvolve diversas frentes de trabalho com a capoeira angola.

A capoeira angola é uma arte, é um saber, é uma manifestação da cultura popular afro-brasileira, com uma dinâmica de ensino e aprendizagem que se fundamenta nos processos pedagógicos primordialmente de matriz africana. Estão representados na figura de mestres e mestras, os principais agentes de transmissão desse saber. Por isso 
costumam ser considerados fontes de sabedoria, incorporada em práticas cotidianas que alimentam a arte da qual se nutrem. São guardiões que zelam pela ancestralidade da capoeira.

$\mathrm{Na}$ história da capoeira angola, é recente o reconhecimento das mulheres como mestras de capoeira. Por muito tempo este reconhecimento foi monopolizado pelos homens, seguindo a tradição da sociedade patriarcal na qual estamos inseridos. $\mathrm{O}$ grupo nZambi de capoeira angola, foi um dos primeiros a ser criado por uma mulher, sendo a mestra Elma considerada hoje uma importante e zelosa divulgadora dessa arte. Isso se dá principalmente através do seu trabalho nos principais núcleos do grupo nZambi, um em Brasília-DF e o outro em Florianópolis-Santa Catarina.

A relevância dos saberes transmitidos pelas mestras e mestres, nos permitem considera-los fontes primárias de conhecimento, tal qual a nascente que alimenta diversos rios. Por isso acreditamos que "beber da fonte" pode possibilitar uma compreensão mais profunda dos fundamentos e da filosofia da capoeira angola, ou mesmo como coloca Rita Marisa Ribes Pereira (2011), ampliar nossa visada, nosso ângulo de observação. Neste sentido, consideramos quão importante seria para este estudo estar em convívio com a mestra Elma.

Além disso, como já mencionado, foram muitos os anos em que a mulher sofreu diversos tipos de exclusão no universo da capoeira, seja enquanto capoeirista ou até mesmo enquanto personagem ignorada nos relatos da história. A mestra Elma é uma representante da luta das mulheres por respeito e reconhecimento, seja na capoeira ou na sociedade em geral. $\mathrm{O}$ fato é que ainda vivenciamos inúmeras restrições, violações e práticas de invisibilidade, portanto é chegado o momento também de nos engajarmos na produção de trabalhos acadêmicos que contribuam para visibilizar a atuação das mulheres capoeiras.

Os pontos apresentados foram a motivação para que esta pesquisa fosse realizada no núcleo do grupo nZambi em Florianópolis, local onde atualmente vive a mestra Elma.

\subsection{Contexto da pesquisa}

Esta pesquisa qualitativa se desenvolveu através de um estudo de caso, possibilitado por meio de uma vivência no ambiente do grupo nZambi de capoeira angola, em Florianópolis-Santa Catarina. O estudo de caso, é uma metodologia que nos 
possibilita dentre outras coisas, conhecer um pouco melhor realidades específicas, casos específicos. Normalmente esse recurso metodológico conta com o respaldo da pesquisa de campo, da observação, da entrevista e outros instrumentos tais como, documentos, fotografias, vídeos, e outros mais.

Este estudo de caso se desenrolou através de uma pesquisa de campo com três meses de duração, tendo a pesquisadora vivido por este tempo in lócus. Esta parte deste estudo foi realizada na Ilha de Florianópolis, no Estado de Santa Catarina, na região sul da ilha, em uma comunidade de pescadores, cultivadores de terra, curandeiras e curandeiros, trabalhadores, artistas, mata nativa, cachoeira, mar, rochas, plantas de poder, vento sul, casas de madeira, bruxas e muito mistério. Este também é lugar de capoeira angola, e mais especificamente na região da Costa de Dentro, acontecem as aulas do grupo nZambi de capoeira angola, sob coordenação da mestra Elma.

A Costa de Dentro é uma comunidade no sul da ilha de Florianópolis, onde vive a mestra Elma e onde desenvolve trabalhos de capoeira angola com adultos e crianças. Seu trabalho não se restringe a esta região, pois desenvolve outros trabalhos com a capoeira em diversas regiões de Florianópolis, principalmente em centros comunitários e escolas. Ao viver de setembro até o fim do mês de novembro nesta comunidade, foi possível ter contato com o mesmo contexto social em que está imersa a mestra. Acredito que essa vivência possibilitou compreensões um pouco mais aprofundadas em torno das reflexões sobre a capoeira angola.

Para este estudo de caso, consideramos que viver na mesma comunidade onde está vivendo e trabalhando a mestra Elma, é muito mais que uma possibilidade de pesquisa, é uma possibilidade de aprendizado, já que os saberes vivenciais da capoeira angola proporcionam ensinamentos para a vida, primando por seus aspectos sagrados através do auto-conhecimento, fortalecimento das capacidades do ser e sabedoria nas formas de interagir com o que há em nós e a nossa volta. Além dos ensinamentos que chegavam por meio das relações com a comunidade e com a natureza, esta pesquisa de campo possibilitou um contato mais profundo com a capoeira angola, pois as observações realizadas foram de natureza participante, logo houve a oportunidade de vivenciar os ensinamentos transmitidos pela mestra.

Esta é uma pesquisa realizada por uma pessoa que vê de dentro, que estuda um grupo do qual faz parte e que vivencia o potencial transformador da capoeira angola. Este fato, é motivador para a busca de fontes de dados variadas, para garantir que outros 
olhares e elementos possam contribuir neste estudo, garantindo-lhe maior legitimidade. Além da bibliografia sobre as temáticas abordadas neste trabalho recorremos a todo instante às entrevistas, ao relato oral, fontes documentais, fotografias, vídeos, músicas. Assim, pretendemos relatar os ensinamentos que foram transmitidos pela mestra Elma, durante os meses de setembro, outubro e novembro do ano de 2013, por meio das aulas ministradas no Conselho Comunitário da Costa de Dentro (CODEN), além do relato sobre a roda de capoeira do grupo nZambi. Como instrumento de pesquisa da observação participante, foi adotado um diário de campo descritivo e reflexivo, onde eram descritas as aulas de capoeira na ordem cronológica de sucessão dos fatos. Além disso, foram realizadas entrevistas com os participantes do grupo nZambi de capoeira angola em Florianópolis, a fim de acrescentar a este trabalho perspectivas que possam corroborar ou refutar as observações realizadas.

\subsection{Métodos e estratégias de pesquisa}

\subsubsection{Método qualitativo}

O método de pesquisa qualitativa é aquele que segundo Creswell (2010), tem sua coleta de dados realizada no campo, ou seja, no local onde geralmente é vivenciada a situação de pesquisa, de modo que esses dados nos chegam por meio da conversa direta com as pessoas e da observação contextualizada, já que o ambiente natural possibilita interações face a face. A pessoa que realiza a pesquisa é responsável por elaborar seus próprios instrumentos de coleta e por acessar pessoalmente os dados com os quais pretende trabalhar, de modo que estes derivam de fontes múltiplas de coleta.

É um método de pesquisa imbuído de filosofia, através das lentes teóricas que serão usadas no estudo e que muitas vezes se organizam em torno da identificação de um contexto social, político ou histórico de uma questão a ser estudada. É uma forma de investigação interpretativa, onde os pesquisadores interpretam o que ouvem, enxergam e entendem, de modo contextualizado.

\subsection{Estratégia}

\subsubsection{Estudo de Caso}

O estudo de caso foi a estratégia da qual se valeu esta pesquisa qualitativa, de modo que nos permitiu lançar um olhar direcionado à realidade estudada bem como às 
suas especificidades. Assim como afirma Creswell (2010), esta estratégia nos permite investigar de forma aprofundada um programa, um evento, uma atividade, um processo, um ou mais indivíduos. Desse modo, nosso estudo de caso se direciona ao grupo nZambi de capoeira angola, e mais especificamente, às suas atividades em Florianópolis-Santa Catarina. O estudo de caso nos possibilitou realizar uma coleta de dados em torno dos processos de ensino e aprendizagem na prática desenvolvida pela mestra Elma, uma das poucas mulheres a conduzir hoje em dia um grupo de capoeira angola.

Para respaldo dessa estratégia, utilizamos de instrumentos tais como, a observação participante, a entrevista semi-estruturada e o relato oral.

\subsection{Instrumentos de pesquisa}

\subsubsection{Observação participante}

Um dos instrumentos de coleta de dados nesse estudo foi a observação participante, de modo que a pesquisadora participou das atividades desenvolvidas, durante o período da pesquisa. As observações foram registradas em um diário de campo reflexivo, seguindo a ordem cronológica dos fatos. O diário de campo é um instrumento que possibilitou o registro das observações participantes realizadas neste estudo, mediante um roteiro de observação. Este diário segue a descrição cronológica dos fatos observados, com ênfase nos tópicos do roteiro, não se restringindo a ele. Além disso, o diário contém reflexões sobre alguns pontos observados.

\subsubsection{Entrevista semi-estruturada}

Foram elaboradas questões abertas a fim de suscitar opiniões e concepções em torno da temática abordada. Foram semi-estruturadas, pois a amplitude do tema extrapolava as questões pré-estabelecidas. Foram realizadas entrevistas com os integrantes do grupo nZambi de capoeira angola em Florianópolis, com a mestra Elma e também com a vice-presidenta do CODEN.

$\mathrm{Na}$ entrevista realizada com os camaradas do grupo nZambi, foram elaboradas questões em torno do ensino e aprendizagem da capoeira, com um foco nas transformações e concepções de mundo proporcionadas por esse processo de formação. Essas entrevistas foram gravadas e aconteceram principalmente no espaço do grupo nZambi em Florianópolis, apenas uma camarada foi entrevistada em sua casa. 
Nas entrevistas realizadas com a mestra Elma, foram elaboradas questões em torno da sua história de vida, relacionada com a criação do grupo nZambi de capoeira angola ainda em relação com sua trajetória enquanto transmissora deste saber. Em muitos momentos suas narrativas respondiam à perguntas que não precisavam de ser feitas. Essa entrevistas foram gravadas e realizadas no espaço do grupo nZambi de Brasília, no espaço do grupo nZambi em Florianópolis e também na casa da mestra Elma.

$\mathrm{Na}$ entrevista realizada com a vice-presidenta do CODEN, foram abordadas questões que nos possibilitassem compreender melhor as atribuições do conselho comunitário e seus vínculos com a comunidade da Costa de Dentro. Essa entrevista foi realizada no espaço do CODEN.

\subsubsection{Relato oral}

Para além das observações realizadas, boa parte desta pesquisa foi possível à partir dos relatos das pessoas que vivem na comunidade da Costa de Dentro, dos camaradas do grupo nZambi de capoeira angola em Florianópolis e principalmente os relatos obtidos por meio de entrevistas e conversas informais com a mestra Elma.

Os relatos da mestra foram imprescindíveis para a reconstrução narrativa da história do grupo nZambi, possibilitando compreendê-lo em seus espaços de ação, enquanto compartilhamos do ponto de vista de Michel de Certeau (2012), de que os contratos narrativos, assim como a compilação de relatos se compõem de fragmentos tirados de histórias anteriores e " bricolados" em um todo único. Esclarecem a formação dos mitos, fundam e articulam espaços. A narração oral não cessa em seu trabalho interminável de compor espaços, verificar, confrontar e deslocar suas fronteiras. E dentre outros por menores " abre um teatro de legitimidade a ações efetivas" ( p. 192).

\subsection{Análise dos dados}

Afim de relatar os resultados dessa pesquisa e realizar a consequente discussão dos dados, seguiremos a seguinte trilha: iremos abordar a história do grupo nZambi de capoeira angola, culminando nas suas atividades realizadas em Florianópolis. Neste ponto serão apresentados os relatos da observação participante em diálogo com os dados das entrevistas e o arcabouço teórico selecionado para tal, realizando uma descrição reflexiva, que tem como busca não apenas dar forma aos achados da pesquisa, como contar da pessoa que a produziu, dando-lhe acabamento. "Esse acabamento será aqui 
tratado como uma experiência estética, uma vez que, para além do conhecimento produzido no campo em que a pesquisa se situa, a prática da pesquisa é formadora de um modo próprio de percepção do mundo, do outro e de si mesmo" (RIBES, 2011, p. 228) 


\section{CAPÍTULO 5 - " CORTA A CABAÇA ESPALHA A SEMENTE"}

\subsection{Trajetórias do grupo nZambi de capoeira angola}

No ano de 1986, Elma Silva Weba, a mestra Elma passou a se criar praticamente sozinha na cidade de São Luís do Maranhão. Na década de 1970 sua família iniciou a trajetória nordestina de migração a outras regiões do Brasil na perspectiva de melhores condições de vida. No ano de 1986, sua mãe e seus dois irmãos, foram ao encontro destes familiares na capital federal, Brasília. No Distrito Federal, mais especificamente na região do P.Norte-Ceilândia, essa família maranhense iniciou um trabalho sagrado com a Umbanda, ao fundar o Terreiro do Vô Congo, sob a coordenação da Mãe Zenit de Oxum. Mais tarde a mestra Elma também se juntaria à sua família e aos trabalhos espirituais do terreiro.

Quando praticamente todos os familiares se direcionaram para o centro do Brasil, a mestra iniciou em São Luís do Maranhão o encontro com uma outra família: a Escola de Capoeira Angola Laborarte, sob coordenação de Antônio José da Conceição Ramos, o mestre Pato ou Patinho. Com esta escola de capoeira foram estabelecidos laços de comunidade, amizade e irmandade, de modo que aos poucos, a capoeira que encantava por sua corporeidade e musicalidade foi se tornando uma filosofia de vida e logo um ofício. Aos 19 anos de idade, a mestra Elma, inicia o aprendizado da capoeira angola e passa a dedicar a sua vida à capoeira:

Eu tive vivência de teatro, estudei teatro, fui atriz, viajei pelo interior do Maranhão todo, esse teatro do Brecht, né, político. Trouxe muito do teatro pro meu trabalho com a capoeira, essa questão política com o social, muito é do teatro, fiz dança. Mas a capoeira foi acontecendo, foi vindo e foi me preenchendo, foi me transfigurando, me dando uma firmeza, me puxando pra terra e dizendo: foi pra isso que estou aqui, eu vim pra cá, com esta missão da minha vida de cultuar a capoeira, levá-la. Devolver um pinguinho do que ela me deu, do que ela me dá. Foi quando eu vi que o meu ofício era a capoeira (...) pra mim ,o ofício, ele vem com esse reencontro, assim de eu encontrar essa manifestação e dizer: eu vou comer, dormir, sonhar, respirar, tudo, pensando no que essa manifestação me dá. Ela vai me dá isso. Se for muito, vai ser muito. Se for pouco nunca vai ser pouco ( mestra Elma).

Ser mulher capoeira na década de 1980, apresentava dificuldades ainda maiores que aquelas enfrentadas nos dias de hoje. As mulheres que se propunham a adentrar esse universo historicamente ocupado pelos homens eram alvo de diversos preconceitos. Assim como hoje, não era tão simples para uma mulher ser reconhecida como capoeira. 
Ora ocupando papéis secundários dentro dos grupos, ora percebida como um ser frágil ou estigmatizada como um ser másculo, as mulheres capoeiras enfrentaram uma luta tanto com a sociedade em geral, como no interior dos seus grupos de capoeira. Algumas se engajaram na mudança dessa história, dentre elas a mestra Elma.

No ano de 1994, foi reconhecida por seu mestre como professora, começou então a ministrar aulas e coordenar as rodas de capoeira do Laborarte na ausência do mestre Pato. Se dedicou também a aprender e ensinar outras manifestações da cultura popular maranhense como o cacuriá e o tambor de crioula, trabalhando em diversos projetos sociais em São Luís do Maranhão. Em sua formação como capoeira e artista recebeu ensinamentos de diversos mestres e mestras, já que dentro da escola de capoeira angola Laborarte, costuma haver a referência de outras manifestações culturais, como o tambor de crioula e o bumba meu boi. A mestra Elma conta ainda como foi importante para sua formação, enquanto mulher capoeira, a influência das mestras de outras manifestações da cultura popular maranhense:

Com essas manifestações afro maranhenses, que teve e tem hoje como lideranças muitas mulheres, como Dona Teté, que é uma grande referência para nós dentro da manifestação do próprio Candomblé de São Luís, do próprio cacuriá, do próprio tambor de crioula. Dona Teté, estava sempre lá nos orientando, como melhor nos comportar, melhor levar e conduzir aquela manifestação. A Dona Elza, uma senhora que também foi grande referência, uma liderança dentro do caroço, outra manifestação maranhense que é indígena cabocla, né, que tem essa forma de improvisar, de criar música ali na hora, que tem uma criatividade imensa. Dentro dessa referência feminina como mestra, também tem a própria Dona Teresinha Jansen que coordena um grande bumba meu boi de lá e o tambor de crioula. E eu não tinha referência feminina na capoeira, né, não tinha. Tinha de outras mestras, tive mestras, mas não de capoeira. Mas não posso de maneira alguma renegá-las, né, todo caminho que eu faço...primeiramente minha mãe, né, foi uma grande mestra, uma grande guerreira. Liderança dentro do lar. Eu vim de uma família matriarcal, posso assim falar ( mestra Elma).

O processo de formação da mestra Elma junto ao mestre Pato em São Luís do Maranhão, teve uma duração de dez anos. Neste período lhe foram transmitidos ensinamentos ancestrais, com raízes nos saberes de mestres baianos. A linhagem maranhense de capoeira angola tem como maiores referências mestre Aberrê, mestre Canjiquinha, mestre Sapo e mestre Patinho. De modo que seguiu-se a seguinte linha de transmissão de saber: a mestra Elma foi discípula do mestre Pato, que prendeu a arte da capoeiragem com mestre Sapo, que foi aluno do mestre Canjiquinha, discípulo do mestre Aberrê. Outros mestres de capoeira também foram importantes para a formação 
da mestra Elma, ela costuma citar, o mestre maranhense Euzamor e outros mestres baianos como, mestre René, Augusto Januário, Paulo dos Anjos, além dos referenciais de mestre Pastinha.

Após dez anos de aprendizado da capoeira maranhense, a mestra Elma inicia uma trajetória que nos permite percebê-la, como uma importante expoente de divulgação da capoeira e cultura do maranhão, assim como enfatiza o mestre de capoeira Nelsinho, a mestra Elma, está sempre " levando o nome da capoeira do Maranhão, do Laborarte e do mestre Patinho aonde vai e acaba sendo a nossa porta-voz, além de ter um belo trabalho. Elma já está entre os grandes nomes da capoeira do país...” ( O Imparcial, São Luís, sexta-feira, p. 16-17 de dezembro de 2010).

No ano de 1995, é convidada a oferecer oficinas de capoeira angola a um grupo de jovens em Porto Alegre, Rio Grande do Sul. Esses jovens faziam parte de um grupo terapêutico-pedagógico de Somaterapia. A Soma é uma terapia que se realiza em grupo e foi preconizada pelo anarquista Roberto Freire, a partir da obra de Wilhelm Reich e pesquisas sobre corpo e emoção. É uma terapia que visa oferecer ferramentas para que as pessoas possam ampliar suas lutas por mais autonomia nos planos emocionais, sociais e ético-políticos. Aborda conceitos de organização vital da Gestalterapia, estudos sobre comunicação humana Antipsiquiatria e a arte-luta da capoeira angola (http://www.somaterapia.com.br/ , acesso: 05/05/14). Ao perceber o interesse desses jovens em darem continuidade ao aprendizado da capoeira angola, a mestra Elma, passa a residir na capital gaúcha.

Ela relata, que ao partir de São Luís do Maranhão para Porto Alegre, leva consigo sua capoeira e também diversos elementos da sua cultura, assim como seu jeito de falar, o sotaque maranhense, o jeito de cantar, de relacionar, de chegar e de acolher. Ao espalhar essas sementes, o envolvimento com a transmissão dos saberes da capoeira angola, culmina com a criação do grupo de capoeira angola Solta a Mandinga. Foram sete anos de trabalho na capital gaúcha, de um trabalho engajado de ensino e aprendizado. A mestra Elma destaca que transmitir os saberes da capoeira angola, foi para ela uma grande fonte de aprendizado da arte:

Porque quando você está ensinando, você está aprendendo. Resolvi trabalhar com capoeira e resolvi vou trabalhar com a capoeira, vou me dedicar ao estudo. Percebi que era a única forma de eu estudar a capoeira, porque eu me sinto uma eterna estudante de capoeira. E aí eu comecei nessa jornada de estudo e de pesquisa dela comecei a dar 
aula. E aí foi vindo pessoas e ao ponto de eu dizer: por que elas vem aprender comigo? Né, eu me questionava. Sei tão pouco. E com pouco, no momento em que eu trocava com elas eu via que aquilo ia aumentando aquele saber. E aí uma vontade de estudar, de pesquisar e elas comigo. Então agente descobria coisas juntos. ( mestra Elma)

O trabalho com a capoeira em Porto Alegre, vai se engajando em diversas frentes de ação e no ano de 1999 o grupo de capoeira angola Solta a Mandinga é rebatizado e passa a se chamar grupo de capoeira angola nZambi. A capoeira começa a se envolver mais com a comunidade e com as crianças da capital gaúcha. $\mathrm{O}$ grupo nZambi começa a estar em espaços onde a capoeira angola ainda não estava acessando, como as periferias da cidade e as escolas:

Bati na porta da escola e falei que queria levar esse trabalho da capoeira na escola, na educação infantil de quatro a seis anos. E percebi que essa educação infantil, não tinha uma atenção em relação ao trabalho corporal para as crianças. Atenção do corporal, do brincar, aprender brincando. Percebi essa falta de trabalho mais voltado para a educação corporal e resolvi levar a capoeira angola justamente com esse tema mesmo: capoeira angola no ensino e educação popular. E aí o nZambi entrou já com esse trabalho, já levando pras crianças. E engraçado que os pais das crianças começaram a se envolver com a capoeira angola. A criança levava pra casa, né, toda a vivência que ela tava tendo e os pais vieram praticar capoeira angola, as crianças trouxeram os pais para conhecer a capoeira angola. E o grupo nZambi foi se formando, também num processo de querer aprofundar mais na capoeira angola enquanto educação, enquanto cultura, e não ficar focado na questão do esporte como era tão divulgada na época lá em Porto Alegre e no Brasil inteiro. (mestra Elma)

A mestra Elma complementa:

Então o nZambi surge com esse fundamento nisso, de trabalhar a capoeira como cultura, como educação. E aí para crianças, jovens e adultos. E sempre tentando, agregar, reunir, justamente adultos e crianças sem distinção de faixa etária, de idade, ampliando mesmo a questão de sexo, de raça. E foi gerando, foi se formando um grupo bastante heterogêneo, acho que o nZambi tem bastante essa característica da diversidade que tem dentro do grupo. E bastante mulheres, vem entrando essa questão, da questão de gênero, né, desse momento que agente surge com o grupo lá em Porto Alegre vem a necessidade da gente demarcar também nosso espaço enquanto mulheres capoeiristas angoleiras. (mestra Elma)

Anos antes desses fatos relatados, o trabalho da mestra Elma com a capoeira angola já era expressivo e recebia o reconhecimento do seu mestre, o mestre Patinho. Em 1997, o grupo que ainda se chamava Solta a Mandinga realiza um evento de capoeira angola em Porto Alegre. A mestra Elma convida seu mestre para participar do mesmo, este percebe o trabalho que vinha desenvolvendo sua discípula e no fim do evento pede a palavra e reconhece a professora Elma como sua primeira contra-mestra 
de capoeira angola. Segundo a mestra Elma, foi inesperado e surpreendente. Todos que estavam presentes se emocionaram.

Como já citado anteriormente, foram sete anos de trabalho em Porto Alegre. As frentes de atuação foram várias. No ano de 2003, a Mestra Elma deixa três alunos responsáveis por darem continuidade aos trabalhos do grupo nZambi na capital gaúcha, e se direciona ao encontro da sua família no Distrito Federal. Esse encontro era familiar e sagrado. Filha de umbanda e filha de família umbandista, a mestra Elma parte para a capital federal, pela necessidade de assumir compromissos com os trabalhos do Terreiro do Vô Congo, situado no P.Norte - Ceilândia . Dentre os trabalhos assumidos, podemos destacar a entrada da capoeira angola no Terreiro, mediante incentivo da Mãe Zenit de Oxum. Segundo a mestra Elma:

O Terreiro, iniciou com toda a minha família de santo, né, com minha irmã, com minha mãe, minha tia, com meu primo, esses parentes todos. Aí eu vou pra Brasília para reencontrá-los, que eu tinha necessidade de trabalhar, chegou a minha hora também, aí eu vou pra lá trabalhar a minha religião, minha espiritualidade. Aí surgem alunos pra mim desenvolver o trabalho com capoeira, e a capoeira também é minha religião, ela me religa com meus ancestrais, então ela é minha religião. E é meu ofício porque vem de dentro de mim, reencontro com essa força, essa arte. ( mestra Elma)

Este fato fortalece ainda mais os vínculos do grupo nZambi com a cosmovisão umbandista. Vale ressaltar que é histórica a interação entre a capoeira e as religiões de matriz africana. Ainda há muito que pesquisar para compreender com mais profundidade essa relação, mas essa interação normalmente era e é de proteção mútua. Muitos capoeiras protegiam os terreiros candomblé, da perseguição policial, enquanto os terreiros ofereciam proteção espiritual aos capoeiras. Nesse sentindo a mestra Elma afirma que todo o trabalho do grupo nZambi é permeado pela cosmovisão umbandista:

E aí vem a nossa mãe que está sempre orientando agente na nossa caminhada, nos nossos passos, que é a religião, né, a umbanda pra nós é nossa grande norteadora, do nosso comportamento, ela norteia nossos rituais, na nossa prática cotidiana, através de nossos pretos velhos que vão nos orientando, trazendo esse mundo invisível, essa ancestralidade através deles. Os pretos velhos e os caboclos são essas entidades que nos norteiam, seus ensinamentos norteiam como nós vamos levar esse saber ancestral que é a capoeira angola, que está vinculada a matriz afro-brasileira, como a umbanda, que tá o caboclo e tá o negro, tá o africano e tá o indígena. Eles norteiam nosso trabalho. ( mestra Elma)

Os trabalhos com capoeira angola no terreiro do Vô Congo, foram possíveis a partir do engajamento da mestra Elma com alguns alunos do grupo nZambi formado em 
Brasília, Distrito Federal. Ao ser reconhecida como contra-mestra de capoeira em uma roda, a mestra Elma, foi convidada por um grupo de alunos da Universidade de Brasília para ministrar aulas de capoeira angola como atividade de um projeto de extensão da UnB. O grupo nZambi atuou por um período na Universidade de Brasília, principalmente com estudantes dessa instituição. Após o trabalho na UnB, o nZambi atuou na casa do Maranhão e também na região da Candangolândia.

No terreiro do Vô Congo, se engajou no compromisso de trabalhar a aceitação da comunidade do entorno, em relação aos rituais litúrgicos e até mesmo a aceitação em relação à simples presença do terreiro naquele local. A Mãe Zenit de Oxum, entra com a proposta de realizar trabalhos com a comunidade na perspectiva de vencer a distância que havia entre o Terreiro e os moradores do local. Neste sentido foi realizada uma pesquisa por parte do Terreiro do Vô Congo para descobrir quantas famílias havia no local e de que região do Brasil proviam aquelas famílias. Descobriu-se que oitenta por cento das famílias que ali moravam, eram nordestinas e lideradas por mulheres que costumavam criar seus filhos sozinhas.

A primeira frente de trabalho foi oferecer cesta básica a essas mulheres e seus filhos. Logo se iniciaram outras frentes que foram propiciando à comunidade conhecer o Terreiro, entrar na casa, respeitar. Muitas dessas pessoas começaram a participar dos trabalhos da casa, e sem apoio financeiro de qualquer instituição, mulheres e crianças tiveram contato com projetos de capoeira angola, costura, leitura e educação ambiental. Houve também a contribuição de um dos integrantes do nZambi que enquanto aluno de medicina, prestava atendimentos básicos à comunidade.

O grupo nZambi desenvolveu suas atividades dentro do Terreiro do Vô Congo, durante três anos, de modo que os integrantes do grupo também criaram afinidades com essa casa. Ainda hoje muitos são integrantes do Terreiro e daqui vem boa parte do axé e fundamentos desse grupo, assim como explicita a mestra Elma:

Muitos fundamentos do terreiro agente traz, a exigência da própria roupa, nossa vestimenta, a exigência de cumprir com os rituais, a exigência de entender e compreender esses rituais e fundamentos. E isso agente... nosso papel, o preencher da nossa caminhada é dar continuidade, de cultuar essa forma de levar esse trabalho, de ensinar, de aprender, de relacionar uma com a outra, né. A questão da cura humana, da cura interna, que a religião umbanda significa cura, né, e ela traz isso, a cura, nos curamos de males, dos males humanos, dos males da sociedade. ( mestra Elma) 
Por muito tempo o grupo nZambi comemora seus anos de criação e existência com uma roda de capoeira que acontece na festa de Preto Velho que é realizada pelo Terreiro do Vô Congo. Num dia de festa, cachaça, vinho e feijoada recebemos a proteção e o axé dos Pretos e Pretas velhas, dos Vô e das Vó. É uma data especial, em que normalmente somos visitados por irmãos e irmãs, camaradas do Maranhão, da Bahia. Quase sempre a festa termina com tambor, com samba e fogueira.

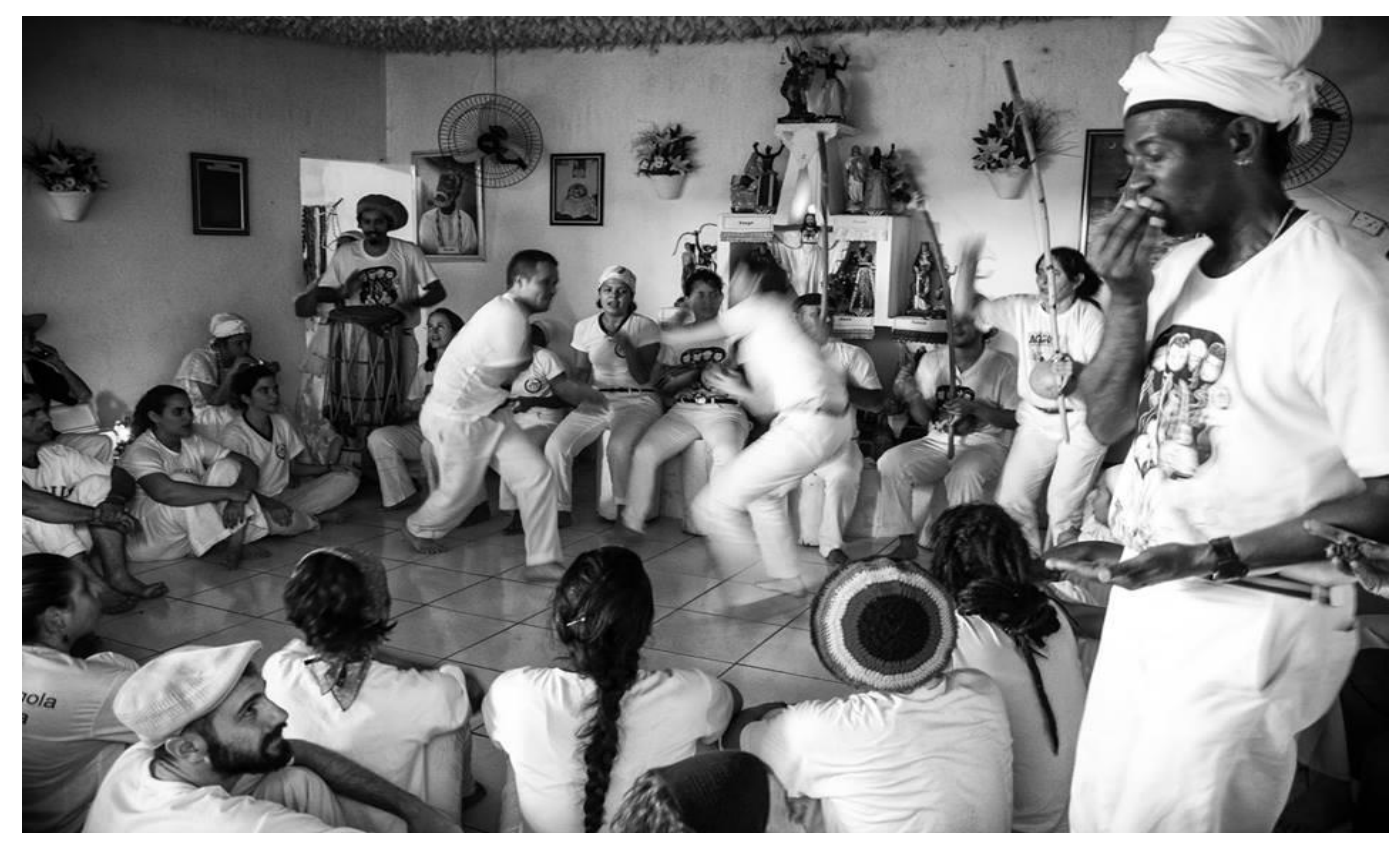

Figura 1: Roda de capoeira no Terreiro do Vô Congo. Evento: "Sob o olhar dos ancestrais". Data: 13 de maio de 2014.

De acordo com o Dicionário Kimbundu-Português de António de Assis Junior (s.d), Nzâmbi ou nZambi é uma palavra que faz parte do tronco linguístico bantu e significa Deus. Não é por acaso que seja este o nome desse grupo de capoeira angola que busca trazer a divindade para seu trabalho. A roda de capoeira é o momento onde podemos fazer o elo com nossos ancestrais, onde cada um pode buscar sua divindade, levando a roda de capoeira para a vida, para o cotidiano. A umbanda é uma grande referência para o nZambi, e sua ancestralidade africana e cabocla se expressa em cânticos que trazem essas presenças para o universo da capoeira angola, juntamente com a filosofia que chega com os cantos tradicionais:

\footnotetext{
É preto é preto

É preto o Kalunga

Capoeira é preta o Kalunga

É preto é preto
} 
É preto o Kalunga o nZambi é preto o Kalunga.

(Domínio Popular)

Nas palavras da mestra Elma:

Nossos cantos são tirados de dentro do terreiro, né, que agente canta para as entidades, na funções de caboclo, dos pretos velhos, dos africanos. Então a nossa forma de aprender e ensinar é tirado muito hoje desses mestres todos que eu tive, e hoje é muito da minha vivência dentro do terreiro. Nós temos muito esses dois como referência assim, essas duas comunidades. Tem que estar ligado com a terra, com a mata, com as águas. O nZambi tá sempre procurando estar ligado a esse espírito e estar sempre zelando por esse elo. Meu trabalho tá vinculado com minha religião, minha religião tá com meu ofício, meu ofício com minha religião ( mestra Elma).

Desse modo as práticas sagradas de ensino e aprendizagem do nZambi, tem como objetivo formar o capoeirista em sua totalidade, através do aprendizado da história da capoeira, sua origem, seus movimentos, a contribuição social da capoeira. Como enfatiza a mestra Elma, é importante para o nZambi, o aprendizado do ritual e fundamentos da roda, o aprendizado da bateria desde o ato de afinar e tocar os instrumentos, à sua confecção. O aprendizado do canto, juntamente com o entendimento das mensagens e complexidade da música. As possibilidades de construir criativamente ladainhas e corridos. Além do aprendizado de como entrar e sair da roda, de como entrar e sair de uma " chamada”. Compreender o diálogo do jogo, a filosofia do jogo, em uma proposta de formação coletiva, através da comunidade do grupo de capoeira. A vivência de um aprendizado em comunidade possibilita a construção em conjunto de um estudo de busca e entendimento da filosofia e dos valores da capoeira, em um processo formativo com ênfase nos aspectos de resistência, identidade e formação da capoeira angola.

No ano de 2007, a mestra Elma decide se mudar da capital federal para a capital catarinense e antes de iniciar seu trabalho na Ilha de Florianópolis, é consolidado um núcleo do grupo nZambi em Brasília, até hoje situado na quadra comercial da 403 norte, na Asa Norte. Esse espaço foi cuidadosamente preparado para a capoeira: foi lavado, defumado e cultuado pelas entidades que acompanham o grupo. $\mathrm{O}$ trabalho foi confiado inicialmente a uma discípula e um discípulo, que tiveram suas capacidades reconhecidas para tal tarefa após anos de dedicação e trabalho com a capoeira angola. Foram os mesmos alunos que assumiram junto à mestra Elma as demandas no terreiro do Vô Congo, e ao longo de anos de convivência diária com a mestra foram mostrando suas potencialidades como educadores, como protetores e guardiães da capoeira angola e do 
grupo nZambi. Foram alunos que tiveram uma convivência intensa com a mestra Elma, logo com a capoeira. A interação era cotidiana e íntima, eles a acompanhavam nas aulas que a mestra ministrava. Frequentavam a casa da mestra, numa relação íntima e iniciática, como a mestra Elma diz: essa coisa sabe?.. de dormir na casa da mestra.

Algum tempo após sua mudança para a Ilha de Florianópolis, a mestra Elma, visita Brasília e se depara com o trabalho que seus discípulos vinham desenvolvendo. Percebe que estava se formando um grupo forte, sem lideranças centralizadas, onde os vários integrantes do grupo estavam encontrando possibilidades de exercer suas capacidades como líderes. Percebe que seus discípulos estavam cada vez se doando mais para a capoeira em uma iniciativa de troca real:

E eles passando aquele saber que eu tinha deixado pra eles, porque realmente aquilo foi passado pra eles por merecimento. E quando eu cheguei lá e vi outros integrantes do grupo zelando, cuidando, se dedicando, preservando, estudando, procurando saber, com interesse pra fazer o grupo acontecer, pela capoeira angola, pela tradição e orientação que os mestres estavam passando...e todos os guardiões que estavam ali presentes em cada movimento, em cada busca. ( mestra Elma)

A mestra Elma relata que os integrantes do nZambi, assim como ainda acontece, estavam sempre em busca de conhecer melhor suas raízes e sua ancestralidade. Desse modo, não era raro as visitas que faziam a São Luís do Maranhão, a fim de beber nas fontes da cultura popular maranhense e principalmente em busca dos aprendizados da capoeira angola com o mestre Pato. $\mathrm{O}$ envolvimento com a capoeira era intenso e verdadeiro. Logo foram surgindo outros integrantes comprometidos com a capoeira e principalmente em conduzir os trabalhos do nZambi quando a mestra estivesse em Florianópolis. Segundo a mestra Elma, o grupo foi se formando por pessoas que além da capoeira, possuíam outras propostas de engajamento e questionamento das problemáticas sociais:

E tendo uma galera no grupo de Brasília, querendo mudar a sociedade do Brasil. Não querendo dar continuidade aquela sociedade individualista, capitalista, né, aquela coisa conservadora daquele mundo de Brasília essa loucura que é. O nZambi vem ali, aquela família, aquela comunidade. Acaba se formando uma comunidade dentro da grande cidade ... aquele corre corre, a competição. O nZambi é uma família, propondo uma mudança de paradigma mesmo da sociedade, da coisa urbana. ( mestra Elma)

$\mathrm{Na}$ Ilha Florianópolis, a mestra Elma, juntamente com dois alunos inicia de forma autônoma um trabalho na região “ bruxólica” (CASCAES, 2012, p. 1) do 
Ribeirão da Ilha, sul da ilha de Florianópolis. Em um espaço cedido pelo clube Bandeirante de Futebol iniciou-se um trabalho com crianças e jovens, logo esse trabalho passou a ser realizado no Conselho Comunitário do Ribeirão da Ilha. A mestra Elma relata que não foi tão simples desenvolver os trabalhos com a capoeira em Florianópolis, porém a partir de um projeto da Fundação Franklin Cascaes, que visava a arte e educação nas comunidades, o grupo nZambi, expande sua atuação para outras comunidades dessa região da ilha, principalmente para a região da Costa de Dentro, comunidade onde ela vive e justamente por isso, contemplada por esse projeto que tem como foco que o arte educador trabalhe em sua própria comunidade. Fato sobre o qual a mestra Elma comenta:

Eu tô aqui, eu quero é oferecer o que eu posso também pra comunidade, né. Todo lugar que eu fui eu sempre quis deixar algo assim, contribuir pro que o lugar tá me dando, né. A capoeira é muito boa pra isso. E comecei a levar pra escola o projeto. É uma forma de chegar na comunidade. Eu moro aqui, é minha casa, eu quero contribuir, quero ajudar a comunidade. Qual o primeiro lugar que você tem que contribuir? Pra sua comunidade. ( mestra Elma)

Desde o ano de 2011, a mestra Elma desenvolve diversas frentes de trabalho com a capoeira angola na Ilha de Florianópolis, dentre elas decidimos voltar o nosso olhar para o processo de ensino e aprendizagem no trabalho desenvolvido com adultos e crianças no Conselho Comunitário da Costa de Dentro ( CODEN ). 


\title{
CAPÍTULO 6 - QUE VENTO TE TROUXE À ILHA DAS BRUXAS?
}

\author{
"Numa tarde de vento sul muito \\ agitado..."
}

(CASCAES, 2012, p. 24)

A Ilha Florianópolis, também chamada de Ilha de Santa Catarina nos fantásticos contos publicados por Franklin Cascaes (1908-1983), se situa na região sul do Brasil. Seu território é formado por uma parte continental e pela região da ilha que se divide em norte, centro e sul. É conhecida nos relatos populares como ilha das bruxas, sendo revestida dos mistérios.

Conversando com os mais antigos, "causos" não faltavam. Dentre muitos dos relatos que me contavam havia a hipótese de que, quando a igreja católica iniciou o processo de caça às bruxas, muitas das mulheres que não foram queimadas na fogueira eram deportadas e "condenadas" a viver pelo resto da vida da Ilha de Santa Catarina. Se o conto é verdadeiro não cheguei a apurar, de onde vieram as bruxas da ilha não poderia com certeza afirmar, só me restava acreditar na "madame Estória" (p. 247), que segundo Franklin Cascaes (2012) é essa senhora que habita vidas fantásticas nos agudos escaninhos do intricado pensamento humano.

Atento e valoroso da cultura popular açoriana, Franklin Cascaes, é considerado também importante personagem da Ilha de Florianópolis, por ter dedicado boa parte da sua trajetória de vida a compilar, por meio de contos, os relatos populares acerca da mitologia e fantasmagoria da ilha. Se dedicou também aos ofícios da cerâmica e do desenho, por meio do qual retratou boa parte dessa mitologia bruxólica. Segundo ele:

A Ilha de Santa Catarina é um autêntico e vivo relicário da cultura popular tradicional reflorida. [ Esta foi] colonizada, a partir do ano de 1748 [ até 1756], por colonos açorianos que habitavam aquelas ilhotas que vivem bem lá em riba da careca do oceano, açoitados diariamente pelas ondas bravias encarneiradas do mar e pelas bocas infernais de vulcões seculares que vomitam fogo e gemem furor incontido sobre as pobres populações [do Arquipélago dos Açores]. Seu povo é mesclado, inteligente, audacioso, de espírito arguto e, sobretudo, religioso e arraigado em crendices mitológicas (CASCAES, 2012, p. 23).

Dentre as crendices mitológicas da ilha destacam-se as figuras dos encantados boitatá, lobisomem, negrinho do pastoreio, saci-pererê e principalmente a figura das bruxas. Na mitologia açoriana, as bruxas estão presentes em toda a costa, realizando "malvadezas", embolando a crina dos cavalos e também soltas pelos ares no embalo 
gelado da melodia assobiada do vento sul. "As mulheres bruxas, afirma a cultura popular fantástica, possuem inteligência ficta agudíssima, que usam em todas as ocasiões precisas para atingir o orgulho, a pretensão desmedida e canhota do pobre homem de barro branco, vermelho, amarelo e preto não coloridos" (CASCAES, 2012, p. 154).

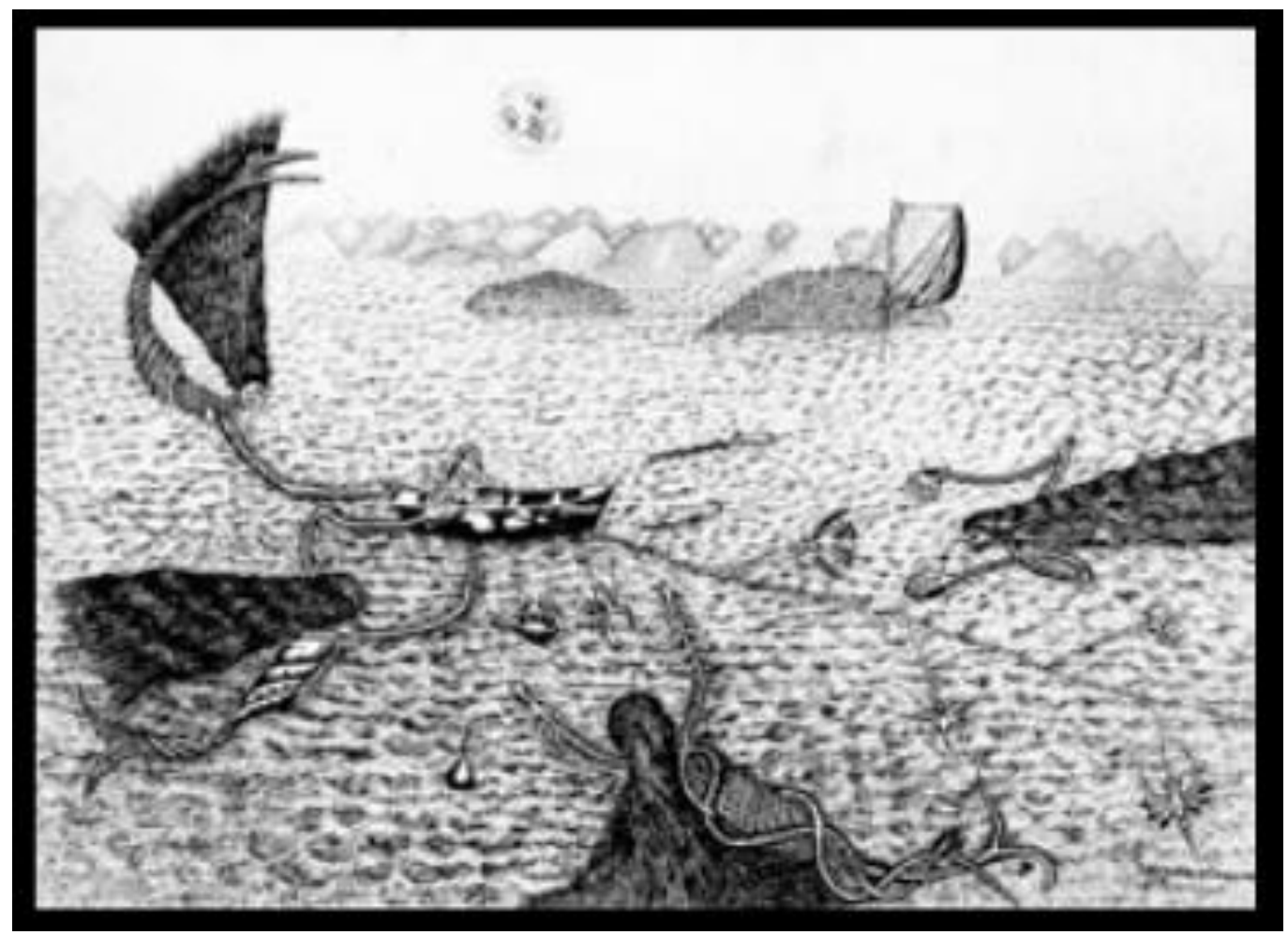

Figura 2: Ilustração na técnica nanquim sobre papel. Título: Bruxas atacam um pescador - Franklin Cascaes, 1973 ( CASCAES, 2012, p. 112)

Além das bruxas e dos encantados, a Ilha de Florianópolis, é habitada principalmente em sua porção sul, por benzedeiras, curandeiras e curandeiros, pessoas dedicadas à pesca artesanal e ao pequeno cultivo da terra. Dentre as culturas destacamse a mandioca, o milho e a cana-de-açúcar. Boa parte das habitações são de madeira, construídas pelas mãos dos próprios moradores em terrenos cercados de mata nativa. Todo o suor e o afeto presente nos modos de criar a própria vida, assim como a aranha que constrói a própria teia.

Quando cheguei na Ilha de Santa Catarina, era um dia de lindo sol. Quem dera eu poder contar que tivesse sido em uma tarde de temeroso vento sul. De qualquer forma o perfume do mar era inebriante. Não me esqueço. É inesquecível também o momento em que comecei a viver no sul da ilha, na região da Costa de Dentro. Aqui se 
iniciou também o convívio com os mitos, com o mar, com a mata, com os pescadores e também com a mestra Elma e meus camaradas integrantes do grupo nZambi de capoeira angola em Florianópolis.

A mestra Elma, vive hoje na comunidade de Costa de Dentro no limite com a Costa de Cima, numa casa de madeira, construída, com a cooperação de camaradas, por ela e sua companheira. São mulheres artesãs que constroem a própria casa, cultivam a terra, as ervas. Esse cenário envolto de mata nativa oferece à mestra os recursos para os artefatos da arte da capoeiragem, seja o rabo-de-macaco ou guatambu que vão virar berimbau, como também as ervas que vão purificar o ritual da capoeira. O contato com a terra, com a água, com os animais e toda a natureza ao redor é íntimo. Vale ressaltar o quanto foi inspirador me deparar com estes modos de vida. Os saberes telúricos, representados mesmo na atitude passarinhesca de construir a própria casa.

A região da Costa de Dentro é banhada pelo mar, conta com a presença de cachoeiras, fontes de água limpa e mata nativa. Seus moradores são trabalhadores, artesãos, pescadores, arte educadores, cultivadores de terra. Tem cultivo de cana-deaçúcar e também um alambique. A cachaça da terra é boa. Tem igrejinha, tem escola municipal e também o conselho comunitário. 


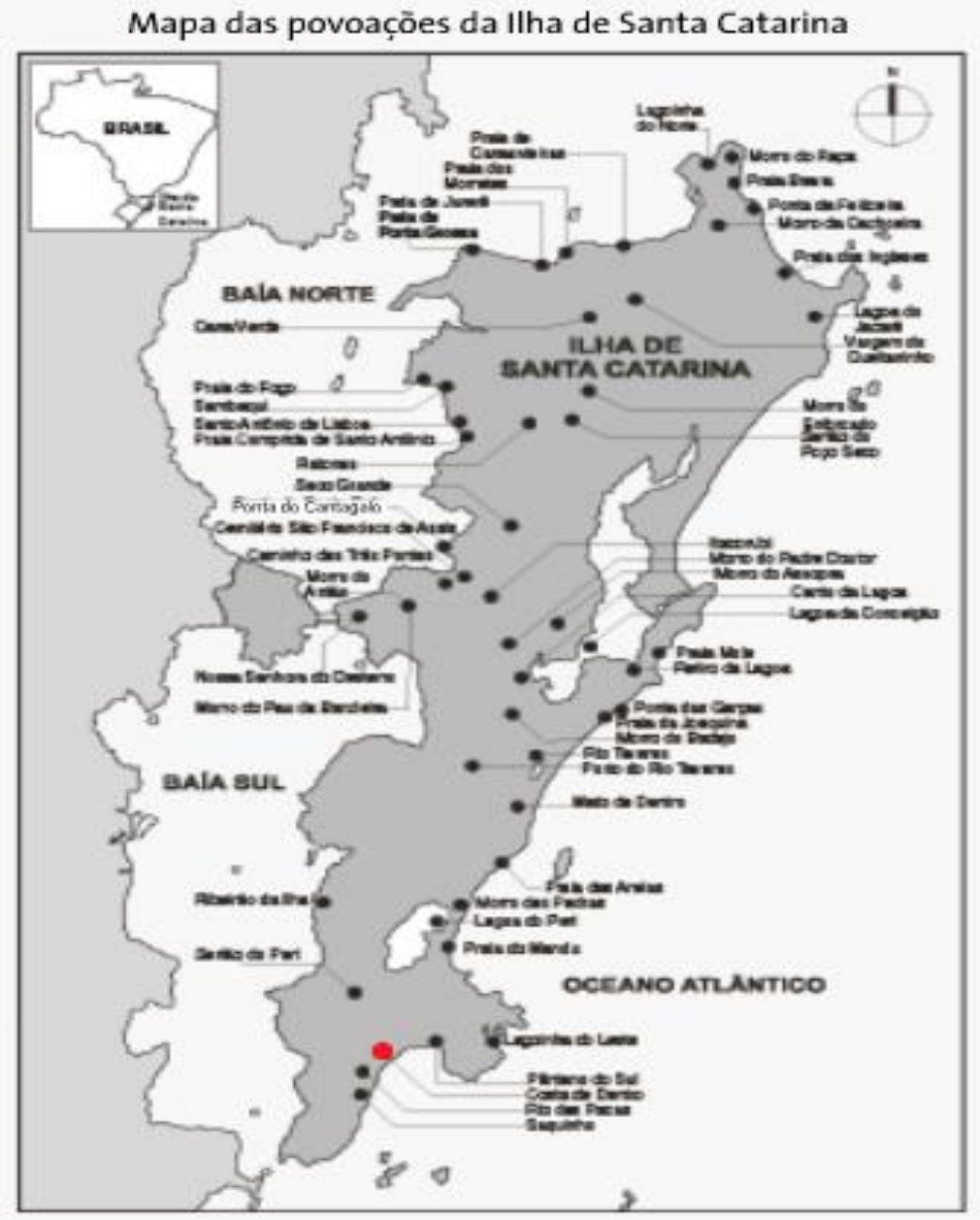

Figura 3: Mapa das povoações da Ilha de Santa Catarina. Destaque ao ponto vermelho onde se encontra a região da Costa de Dentro. 


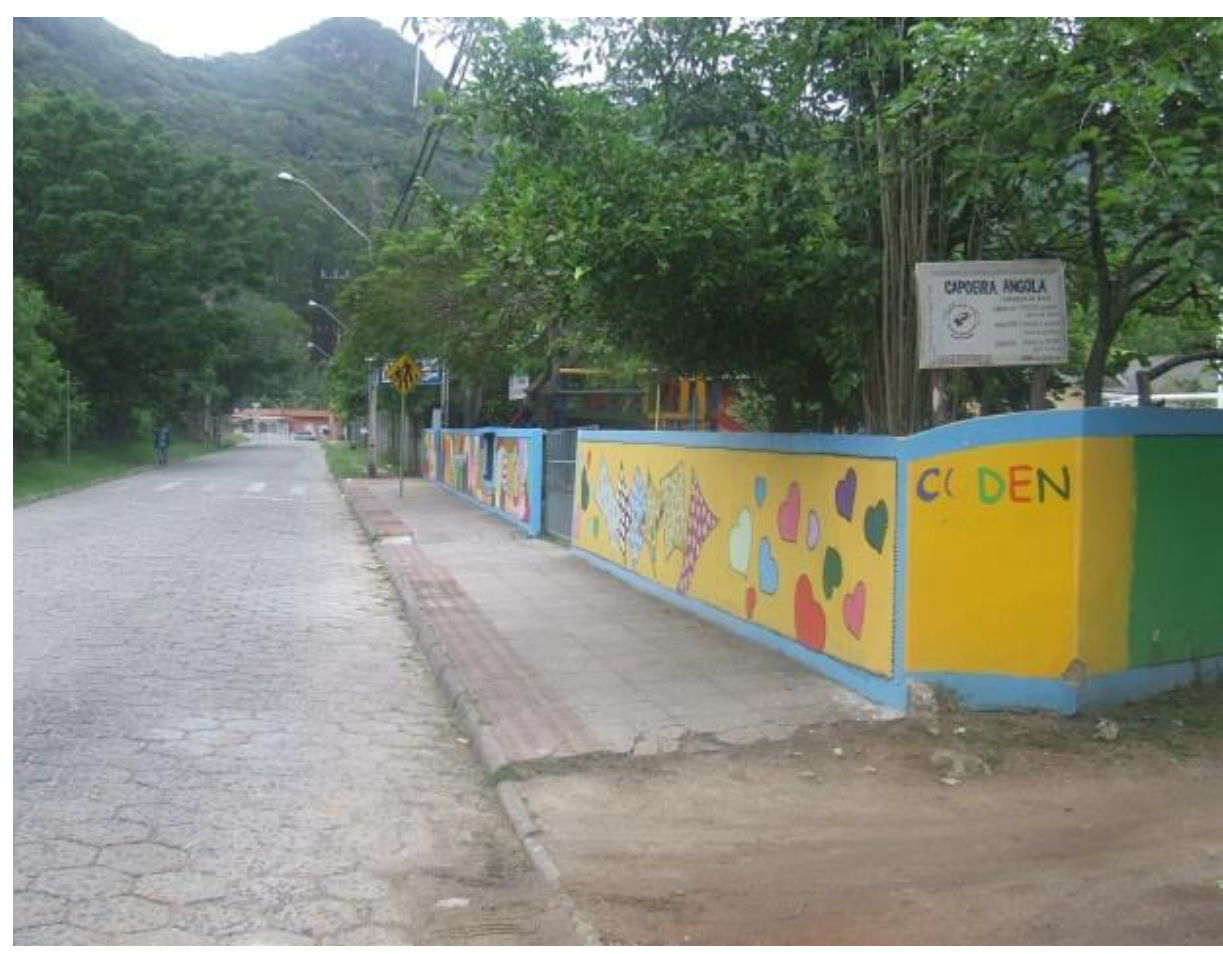

Figura 4: Entrada da Costa de Dentro - fachada da Escola Municipal da Costa de Dentro e entrada do CODEN com placa de divulgação das aulas de capoeira angola com o grupo nZambi.

\subsection{Nossa escola e nossos camaradas}

Praticamente todas as regiões administrativas da Ilha de Florianópolis contam com a presença de conselhos comunitários que são mediadores entre a comunidade e o Estado. Atendem a comunidade em diversas questões como, por exemplo, na distribuição da água encanada para os moradores. Os conselhos comunitários costumam oferecer atividades de formação e realizar eventos na comunidade da qual fazem parte. Segundo a vice-presidenta do CODEN, o conselho comunitário busca captar projetos para a comunidade e viabilizar o uso do espaço para a realização de eventos e atividades que contribuam para fortalecer os vínculos e a articulação das pessoas que vivem na Costa de Dentro. Na imagem abaixo podemos visualizar este espaço: 


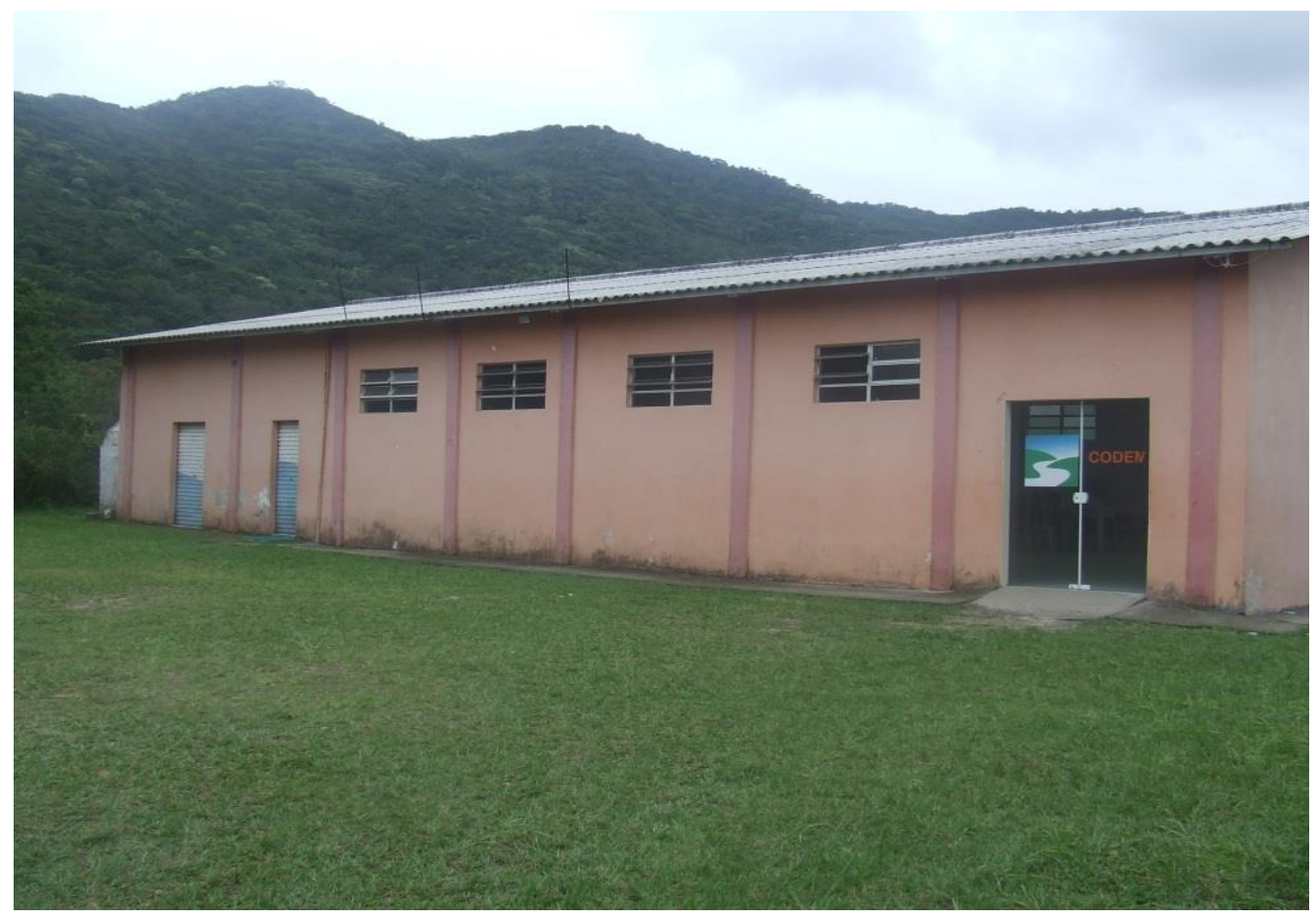

Figura 5: Fachada frontal do CODEN

O Conselho Comunitário da Costa de Dentro (CODEN) é um dos lugares onde a mestra Elma desenvolve as atividades do grupo nZambi de capoeira angola. Atuando na comunidade onde vive, no CODEN, a mestra trabalha com crianças e adultos, de forma mista. Já que muitos pais e mães trazem suas crianças para participarem das aulas de capoeira que acabam por envolver todos no processo.

Esse foi o ambiente onde realizei a maior parte das observações. Onde jogam adultos e crianças, no convívio com suas diferenças e similitudes, num processo de socialização onde os dois universos tendem a interagir sem que crianças e adultos sejam separados em universos distintos. O grupo nZambi de capoeira angola em Florianópolis, é heterogêneo, formado por mulheres e homens, por meninas e meninos, por brasileiros e pessoas nascidas em outros países, camaradas que se encontram em diversos estágios de vivência da capoeira angola, seja pelo tempo que já estão em contato com a arte, seja pelo desenvolvimento pessoal de cada um. No quadro abaixo segue um perfil das pessoas que fazem parte deste grupo:

Tabela 1 - Caracterização dos participantes da Pesquisa 


\begin{tabular}{|l|l|l|l|l|}
\hline Gênero & Idade & Nacionalidade & Profissão & $\begin{array}{l}\text { Tempo de } \\
\text { capoeira }\end{array}$ \\
\hline Menina & 9 anos & Brasileira & Estudante & +ou- 6 meses \\
\hline Homem & 34 anos & Uruguaio & Trabalhador & 9 anos \\
\hline Menino & 4 anos & Brasileiro & Naval & 4 anos \\
\hline Mulher & 34 anos & Peruana & Pedagoga & 11 anos \\
\hline Homem & 48 anos & Brasileiro & Psicoterapeuta & 16 anos \\
\hline Mulher & 25 anos & Mexicana & Artesã & 1 ano e \\
\hline Mulher & 27 anos & Brasileira & Artista Plástica & 8 anos \\
\hline Mulher & 34 anos & Brasileira & Terapeuta & 4 anos \\
\hline
\end{tabular}

O salão do CODEN, onde acontecem as aulas de capoeira é amplo, possui um banheiro masculino e feminino, uma pequena cozinha e um armário onde são guardados os instrumentos musicais do grupo nZambi de capoeira angola. Neste salão também acontecem outras atividades em outros horários. É um espaço compartilhado.

Além das aulas, outra atividade importante do grupo, são as rodas de capoeira que costumam acontecer todos os domingos, que não choviam em frente à Igreja de São Pedro, na região "bruxólica" (CASCAES, 2012, p. 23) do Pântano do Sul. Nos domingos que chovessem, as rodas seriam substituídas por alguma atividade de estudos que aconteceria na casa da mestra Elma. Na Ilha de Santa Catarina chovia quase sempre, mas desde que iniciamos as nossas rodas em frente à Igreja de São Pedro, todos os domingos durante os três meses que estive na ilha foram de sol, exceto um domingo em especial que realizamos um dia de estudos na casa da mestra Elma. 


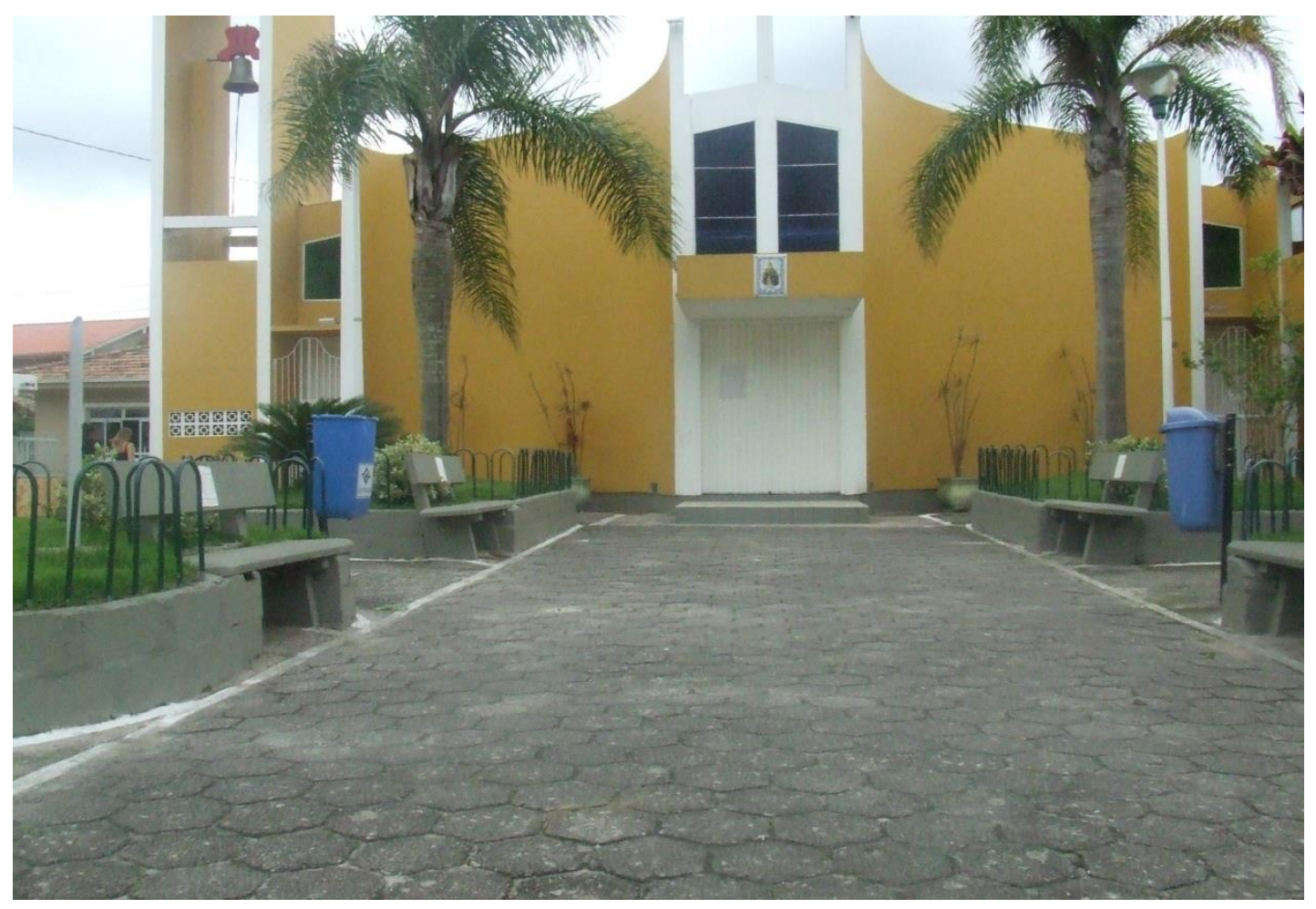

Figura 6: Fachada frontal da Igreja de São Pedro - Pântano do Sul.

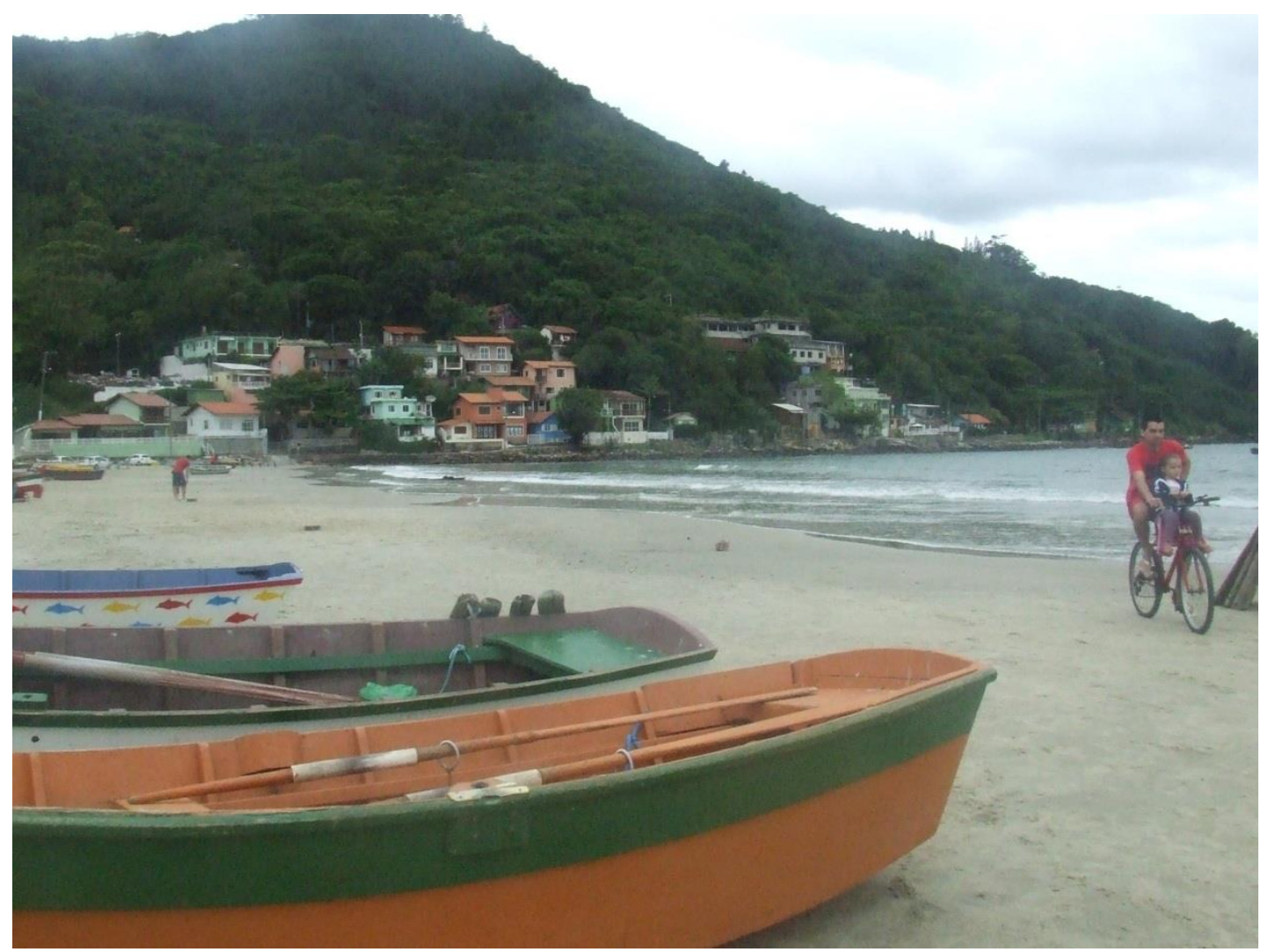

Figura 7: Praia do Pântano do Sul 


\section{2 "Foi na beira do mar..."}

O Conselho Comunitário da Costa de Dentro, é mais um dos conselhos comunitários onde a mestra Elma desenvolve trabalhos com a capoeira angola, e também foi o lugar escolhido para a realização desta pesquisa. O projeto da capoeira angola do grupo nZambi, é uma parceria deste com o CODEN, e por meio desta relação são oferecidas à comunidade e entorno aulas de capoeira nas terças e quintas-feiras das 19:00 às 21:30 horas.

Durante o período de setembro a novembro, em que foi realizada esta pesquisa alguns fatos eram rotineiros tais como, a limpeza do salão do CODEN antes do início das aulas e a preparação dos instrumentos musicais.

Às 19:00 iniciavam os trabalhos de capoeira angola, com a mestra Elma. Buscávamos chegar no horário a fim de evitar quebrar a energia das atividades que seriam desenvolvidas, além disso essa era uma das exigências da mestra. Capoeira é disciplina. Dentre os preparativos para as aulas estavam a limpeza e arrumação do lugar. O salão do CODEN, como já citado, era compartilhado com outros membros da comunidade que ao realizar seus encontros e atividades, nem sempre o deixavam limpo e organizado, muitas vezes tínhamos também que lidar com alguns entulhos e materiais de construção que acabavam ficando no espaço em função de reformas que vinham acontecendo para sua melhoria. Organizar este espaço, era uma das nossas demandas.

À medida que os camaradas iam chegando, cada um assumia uma função tanto na limpeza e preparação do espaço, quanto na preparação dos instrumentos musicais. $\mathrm{O}$ salão era varrido, limpado e por vezes defumado. Cadeiras eram organizadas em círculo onde mais tarde seria formada a bateria. Os berimbaus eram armados e todos os instrumentos eram afinados. Capricho, tudo era organizado com muito cuidado e capricho. Cada detalhe era imprescindível para formar a harmonia das aulas. O trato aos instrumentos musicais da capoeira, ou à qualquer elemento que lhe correspondesse era delicado e minucioso. Cada berimbau era uma arte. Cada artefato uma história.

Não havia uma função privilegiada. Todos poderiam realizar qualquer atividade que demonstrassem capacidade para. Cuidávamos do espaço do qual iríamos usufruir e o fazíamos em conjunto, em grupo de forma colaborativa. Esse ritual antes de tudo já se 
configurava em um profundo ensinamento que transcendia o momento das aulas de capoeira. Assim uma camarada:

É uma oportunidade de viver e de aprender a viver diferente da sociedade, do sistema que é apresentado. Essa forma que agente se organiza. Agente circula, tá sempre assim fazendo toda as funções, experimentando todas né, não existe só uma coisa como nos departamentos, lojas e fábricas. O sistema como é cada coisa no seu lugar e você não experimenta.

E outra também:

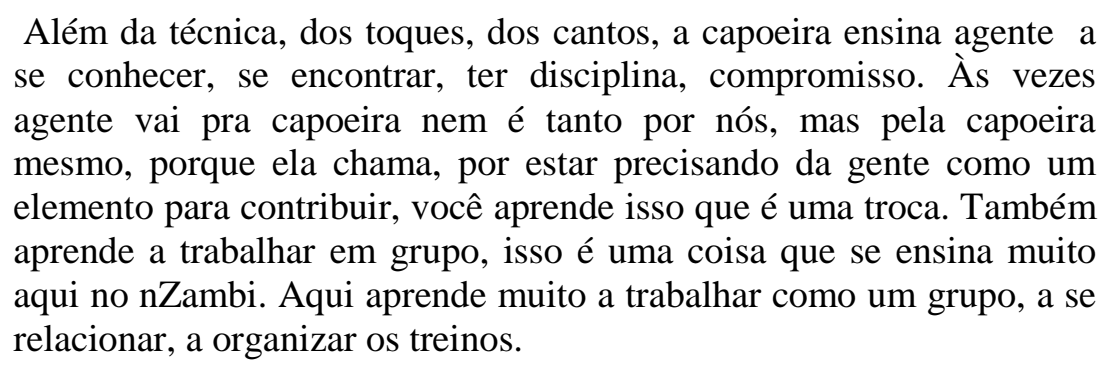

Os ensinamentos que provinham da divisão colaborativa das tarefas, nos permitiam entrar em contato com uma forma de relacionamento comum, onde cada qual na sua diferença e capacidade se comprometia a realizar uma função. Estávamos uns com os outros, buscando vibrar por meio de um importante valor do grupo nZambi: a cooperação. O trabalho coletivo, não apenas cumpria com a expectativa imediata de estar em um ambiente limpo e organizado. Fazíamos por nós e nesse tom aprendíamos muito de nós. "A cooperação natural começa, assim, pelo fato de que não podemos sobreviver sozinhos. A divisão do trabalho nos ajuda a multiplicar nossos poderes insuficientes, mas essa divisão funciona melhor quando é flexível, pois o próprio ambiente está em constante processo de mudança" (SENNET, 2012, p. 92)

Hoje vivemos a maior parte do nosso tempo sob uma lógica individualizada e competitiva. Assim tem sido em grande parte dos ambientes pelos quais transitamos, sendo esta a tônica de muitas das nossas relações. Esta é uma das problemáticas que estimula os estudos do pesquisador Richard Sennet (2012) em torno da cooperação enquanto um valor a ser reforçado que exige o desenvolvimento de habilidades sutis. Neste sentido ela é uma arte presente na natureza humana, porém desabilitada pela substituição dos seres humanos por máquinas, onde estas foram ocupando o lugar dos trabalhos manuais. Para o autor, cooperamos para conseguir aquilo que não podemos alcançar sozinhos, por meio de trocas onde todos se beneficiem. Com a cooperação, em grupos onde haja pessoas diferentes, temos a oportunidade de estarmos uns com os outros e aprendermos uns com os outros sobre as consequências dos nossos próprios 
atos. "O que significa, de maneira mais genérica, que o que ganhamos com tipos mais exigentes de cooperação é a compreensão de nós mesmos" (p. 17)

Prosseguíamos com nossos treinos nos posicionando em roda, em círculo para dar início às movimentações, raras foram as vezes em que não fizemos isso sob essa configuração. Sem nada dizer, ao som do berimbau, posicionados em círculo, alongávamos o corpo, aquecíamos as articulações, respirávamos. A mestra Elma nos orientava. Iniciávamos a movimentação através da ginga e da mandinga. A ginga permitia aquecer ainda mais o corpo enquanto podíamos buscar compreender as dimensões espaciais ao nosso redor, perceber os camaradas ao lado, à frente, observar as quantidades de espaço que somos capazes de ocupar. A movimentação da mandinga era libertadora e ampliava as possibilidades de transitar no espaço, possibilitando mudar sempre que possível as dimensões do corpo.

Nos depoimentos de uma das camaradas do grupo sobre aquilo que ela considerava relevante no processo de formação que estávamos vivenciando, trazia a referência sobre a predominância dessa configuração circular presente não só nas rodas de capoeira como também em nossos treinos. Em estudos sobre o ser humano e seus símbolos, Carl G. Jung (1967), traz a abordagem de que o círculo expressa a totalidade da nossa psique em todos os aspectos inclusive naqueles que relacionam os seres humanos com a natureza. Essa integral totalização dos aspectos da vida, contribuem para unir o cárater singular da consciência moderna com o passado milenar da humanidade (p. 243). Essa dimensão de totalidade e conexão da capoeira expressa no círculo foi percebida também na voz de outra camarada:

Os movimentos são muito orgânicos, em geral são movimentos circulares, e tem uma conexão com a terra os pés tem que estar firmes e as mãos também. Para mim não existe coisa mais orgânica na natureza que o círculo porque os encontramos em todas as coisas da natureza, como as ondas do mar, as flores, tudo.

Esse movimento circular e integrador ganhava cada vez mais ritmo, cadenciado ao som do berimbau e das vozes dos cantos. A mestra nos ensinava outras movimentações, avanços, recuos, perguntas e respostas. Ainda em roda, tudo acontecia em silêncio e música. Somente os corpos falavam. Aos poucos era possível sentir a mente relaxada e a complexidade dos movimentos, exigiam maior concentração e esvaziamento mental. Todos os eixos do corpo eram desafiados na sua desafiadora relação com o espaço. O recolhimento das pernas no bote da queda de rim, infinitas 
possibilidades de rotação, cabeça no chão e pernas para cima, mãos de apoio e pernas para o ar. O sangue fluindo para vários sentidos, oxigenando todo o corpo. Como estávamos nos movimentando em roda, a atenção, os reflexos e o auto-controle tinham de ser redobrados, além disso era preciso uma conexão do grupo para que ninguém se batesse. Silêncio, não falávamos nada.

Após um tempo de movimentação em círculo, a mestra Elma nos orientava a formarmos duplas para treinarmos movimentos de pergunta e resposta, para dialogarmos ainda mais com os corpos. Normalmente, este era um momento em que buscávamos encaixar os movimentos que havíamos realizado anteriormente, muitas vezes essa parte do treino tinha como proposta perceber as possibilidades infinitas de diálogo presente nas movimentações. Este é um momento em que temos que dialogar, jogar, vadiar, viver a nossa energia em relação com a energia da outra pessoa, é trabalhar a ansiedade para jogar no tempo, de modo que os dois corpos se comuniquem sem nenhuma palavra, sendo o olhar fundamental para esse jogo comunicativo onde impera o silêncio.

Da coluna vertebral ao dedinho da mão, na capoeira angola todo o corpo deve estar acordado, ágil, embora na densidade exata. A ponte, o aú , a inversão da bananeira, a ginga. Expressões corporais bastante estranhas para o nosso cotidiano e imensamente importantes para o desenvolvimento de nossas infinitas possibilidades. O aprendizado dessas movimentações que desafiavam nossa conjuntura corpórea cotidiana, traziam uma reelaboração da presença na vida, extrapolando os níveis da conscientização física, de modo que a aprendizagem da corporeidade trazia ensinamentos cada vez mais sutis. Sara Abreu da Mata Machado (2011), em seu estudo sobre a corporeidade na capoeira, percebe a ginga como uma filosofia de vida, que nos permite descontruir ideias lineares, reconhecendo os processos de constante transformação da vida, na possibilidade de inversão de relações e conceitos:

Falar sobre corpo ancestral, angoleiro, é reconhecer e trabalhar a dimensão corporal em nosso processo de auto-conhecimento e autocuidado. É preciso conhecer o nosso próprio corpo, em suas possibilidades de movimentos, em suas necessidades e limites, para sabermos dele cuidar e ter condições e a disposição para atuar no mundo e cumprir nossas missões da melhor forma possível. Herdamos da nossa matriz cultural africana, a intimidade com movimentos diversos do corpo, tanto na dor como no prazer (p. 14).

Quando não conseguíamos realizar algum movimento, a mestra nos motivava a reconhecer nosso corpo e a realizá-los dentro das nossas possibilidades. Aos poucos um 
e outro ia se encontrando e conseguindo fazer a bananeira, as mandingas e vários movimentos que exigiam muita confiança. Quando conseguíamos a mestra nos animava, incentivava com olhares que confirmavam que estávamos no caminho.

Foram vários os momentos em que a mestra Elma, para explicar um movimento, o fazia realizando a movimentação com algum camarada. Chamava uma camarada ou um camarada e explicava o movimento praticamente com o corpo. Quanto menos palavras, melhor. Cada dia era possível perceber o potencial da " pedagogia do silêncio". O aprendizado através da observação, da abertura dos sentidos e o olhar, o olho vivo, tão importante no momento da roda de capoeira e na vida. Em silêncio era possível uma percepção mais profunda da respiração, do ambiente e dos ensinamentos. Era como um verdadeiro processo de meditação ativa e coletiva.

O silêncio é um dos principais elementos para o desenvolvimento daquilo que Richard Sennet (2012), denominou de “ habilidades dialógicas” (p. 17). Indispensáveis ao aprendizado da cooperação, estas habilidades pressupõe o desenvolvimento da comunicação que ouve com atenção e age com tato. Sem nada dizer, estávamos mais predispostos a escutar o corpo das outras pessoas, agindo na medida de cada gesto. De acordo com Richard Sennet (2012), boa parte da sabedoria do diálogo, reside mais na escuta, na observação e muito menos na fala propriamente dita. Neste sentido afirma que aqueles que não observam, não podem conversar. Observar nos permite "ouvir bem", por meio de um conjunto de habilidades que nos permite atentar de perto para o que os outros dizem, interpretando e conferindo sentido aos gestos e silêncios. Observar bem nos permite uma prática mais dialógica e cooperativa, onde as relações vivenciadas de maneira não verbal contam com os gestos corporais no estabelecimento da autoridade, confiança e cooperação. As aptidões, tais como o controle muscular, são importantes para que o corpo comunique, assim como quando nos comunicamos com o corpo, com os gestos, podem surgir sentimentos viscerais. Além disso, acrescenta o autor:

No aprendizado, a opção por " mostrar em vez de dizer" raramente implica em se manter totalmente calado, pois a pessoa à qual se mostra determinado gesto provavelmente fará perguntas, mas o mostrar vem antes do explicar (...) os gestos podem modificar o ritmo do fazer, suspendendo e refazendo hábitos com o passar do tempo (...) é uma representação composta que suspende o envolvimento ativo com as coisas (...) O momentâneo "dar de ombros" pode funcionar como uma pista muda para que a outra pessoa recue, duvide ou pelo menos pense a respeito do que está fazendo. Seja antes, quando uma 
ação foi inscrita como hábito, ou depois, quando é ampliada ou enriquecida, o ritmo é confirmado por gestos que expressam para nós e sinalizam para os outros que temos confiança naquilo que estamos fazendo. ( Idem, ibidem, p. 251- 252)

Não houve uma aula que tenha sido igual à outra. A mestra Elma sempre nos surpreendia com algo novo, o que impedia que nos acomodássemos e buscássemos sempre a reinvenção, o reencontro com a nossa natureza. Ainda assim, foram muitos os treinos em que repetíamos várias vezes os mesmos movimentos. O método da repetição era muito importante para interiorizarmos os movimentos da capoeira e cada dia o ato de jogar, de dialogar, vadiar ia se tornando mais natural. Atenta à importância do desenvolvimento das aptidões musculares para a vadiação, a mestra Elma costumava dizer que a compreensão da filosofia da capoeira era elemento essencial para a realização do diálogo corporal, e esse se tornava ainda mais fluído com um corpo treinado. De fato, o corpo treinado por meio da repetição, tem grandes possibilidades de jogo porque está impregnado de movimento.

Ainda assim, a repetição não garantia apenas a execução de movimentos efetivos. $\mathrm{O}$ ensinamento pode ser interpretado com mais profundidade diante da relação que Richard Sennet (2012) estabelece entre a repetição e a cooperação. Segundo ele, a repetição em grupo proporciona uma estrutura disciplinar, que nos permite repassar repetidas vezes as mesmas coisas, buscando aperfeiçoá-las. A repetição mecânica é apenas um elemento, e desde que atribuímos sentido a essa ação tentamos nos tornar melhores naquilo que fazemos. Por meio de vínculos que nos permitem experimentar e executar conjuntamente gestos, a repetição coletiva pode tornar a cooperação com o tempo tanto mais sustentável, quanto perfectível.

Como já citado anteriormente, havia uma particularidade neste trabalho: a presença das crianças. Eram treinos onde adultos e crianças compartilhavam o mesmo espaço de aprendizagem. Muitos pais e mães capoeiras traziam seus filhos para as aulas, estes desde pequenos já estavam sendo sensibilizados para a capoeira e participavam dos treinos dentro das suas possibilidades. Havia um respeito mútuo entre adultos e crianças e a presença dos pequenos representava uma ruptura aos modelos de educação que tendem a nos separar de acordo com a nossa faixa etária. De acordo com Richard Sennet (2012) "Naturalmente, qualquer classificação por idade é arbitrária; o desenvolvimento é elástico" (p. 23-24). Neste sentido, dizer que o desenvolvimento é elástico significa nos aproximar da sabedoria do velho mestre Pastinha quando afirmou 
que " cada um é cada um". Cada um de nós está em um momento diferente de aprendizado, sendo que a interação com diferentes estágios da vida humana, quando bem orientada pode se transformar numa rica experiência para todas as partes

\begin{abstract}
justamente pela diversidade de faixa etária, estilo de vida. Às vezes agente aprende muito mais com uma criança do que com uma pessoa que tem o mesmo tempo de capoeira que você. Porque a criança te surpreende. As crianças são muito vivas e trazem isso pra capoeira, trazem a simplicidade, a criança não complica muito as coisas. A criança às vezes se insere mais no sentir e aprendem fazendo, interessante como aprendem numa experiência mais livre. Agente às vezes complica muito as coisas, adulto às vezes tenta aprender mentalmente. A criança vai sentindo e vai trazendo. Na criança não existe tanta rigidez como no adulto que já tem seus padrões, treinar com as crianças eu aprendo...desaprendo o que aprendi em um formato formal. ( camarada do grupo nZambi)
\end{abstract}

Era possível perceber a sensibilidade da mestra Elma ao mediar as interações entre o universo dos adultos e das crianças. Ela costumava dizer: "é preciso escutar a criança”. Os pequenos tinham seu tempo respeitado, participavam de todos os momentos da aula dentro das suas possibilidades, recebendo estímulos na medida da criança sem infantilizá-la. No período em que esta pesquisa de campo foi realizada, contávamos com a presença constante de duas crianças: um menino de quatros anos e uma menina de nove anos de idade. Outras crianças vinham com seus pais ou mães de forma mais esporádica. As duas crianças que costumavam estar sempre nos treinos, muitas vezes realizavam as movimentações entre si, gingavam, mandingavam e assim como os adultos, o faziam dentro das suas possibilidades. Por vezes, somente assistiam aos treinos, ficavam na oitiva, na observação. Também se movimentavam juntamente com adultos.

Nas aulas da mestra Elma, quando as crianças não estavam se movimentando, observavam. Um trecho do diário de campo traz um fato interessante: Outro momento da aula foi quando a mestra nos reorientou no espaço para que fizéssemos a " ponte" em dupla. Tínhamos que nos movimentar na ponte cruzando os olhares. Esse movimento se apresenta difícil para a maioria dos adultos, porque exige muitas habilidades: flexibilidade na coluna, abertura do peito, força no braço, auto-controle...treinávamos, e eu treinava com um camarada que sempre trazia seu filho para fazer parte da capoeira. O que importa é que dado um momento o menino saiu de onde estava observando, chegou para perto do pai, para perto de mim e da mestra que observava como fazíamos 
esse movimento. O menino chamou a nossa atenção e realizou a movimentação proposta. Fiquei impressionada, pois nunca pensei que ele ao ficar em um espaço brincando e se movimentando, no tempo do seu mundo de criança, observou e nos abordou para realizar o movimento. Ficamos sorrindo, sem palavras. Me peguei a refletir sobre a presença dessas crianças na aula, e como isso é rico. A possibilidade de troca com as crianças nos possibilita acessar um universo já vivido e " esquecido" devido diversos estímulos para adentrar o mundo dos adultos e aqui ficar. Um mundo de adultos onde não se brinca, não se improvisa, não se vive a curiosidade e o encantamento. Conviver com a espontaneidade, com a sutileza e a simplicidade da criança, nos permite um reencontro, um aprendizado para a vida." ( Diário de Campo, dia 05/ 11/ 2013. terça-feira. local: Salão do CODEN. Situação vivenciada: Aula)

Quando o treino instrumental não acontecia concomitante ao treino dos movimentos, a aula costumava ser dividida em um momento para o treino de movimentações e um momento para o aprendizado da parte musical da capoeira. Houve situações em que tivemos aula de bateria, ou seja um treino inteiramente dedicado ao aprendizado da parte instrumental da capoeira. No grupo nZambi, a bateria é muito valorizada. A musicalidade ocupa o mesmo lugar de importância que a movimentação corporal. Este é um aspecto que encontramos também nos relatos de outros mestres da nossa linhagem. Sobre a musicalidade na capoeira mestre Canjiquinha revelava:

Eu sei muitas cantigas de capoeira, de samba de roda. É um dom meu. Naquele tempo, eu tinha memória boa. Então, eu aprendia as cantigas rápido e fácil. Eu aprendia no candomblé. Via minha mãe e minha tia tocando e cantando. Tinha samba de roda nos aniversários. Eu ensinava aos meus alunos como eu faço com vocês: ficamos aqui treinando, porque vocês têm que cantar também. Qualquer aluno meu sabe tocar e cantar, porque é obrigação do mestre saber para transmitir (GAFANHOTO, 1989, p. 35).

\subsection{O aprendizado da musicalidade}

Sentávamos em cadeiras organizadas em círculos, ou semi-círculos. Cada aula havia uma proposta nova em relação às possibilidades de aprendizado da bateria. Houve momentos em que todos nós tocávamos berimbau. Eram treinos de berimbau. Havia momentos em que treinávamos com todos os instrumentos da bateria. Na maioria das 
vezes os instrumentos eram revezados. Música, canto, gestos e olhares, essa era a comunicação.

Boa parte da efetiva comunicação entre músicos consiste em movimentos de sobrancelha, resmungos, olhares de relance e outros gestos não verbais. Mais uma vez, quando os músicos querem explicar algo, tendem antes a mostrar do que dizer, (...) O bom ouvinte precisa estar atento às intenções, às sugestões, para que a conversa siga em frente. (SENNET, 2012, p. 30-31)

Nos olhávamos e nos escutávamos. A mestra nos ensinava como tocar cada instrumento, era o momento do treino coletivo, porém nosso desenvolvimento dependia também da dedicação de cada um. O exercício da escuta fortalecia a atenção e a interação do grupo, era também boa possibilidade para trabalhar a abertura de outros sentidos e ampliar a percepção dos vários fragmentos sonoros que compõem a realidade. As crianças também participavam.

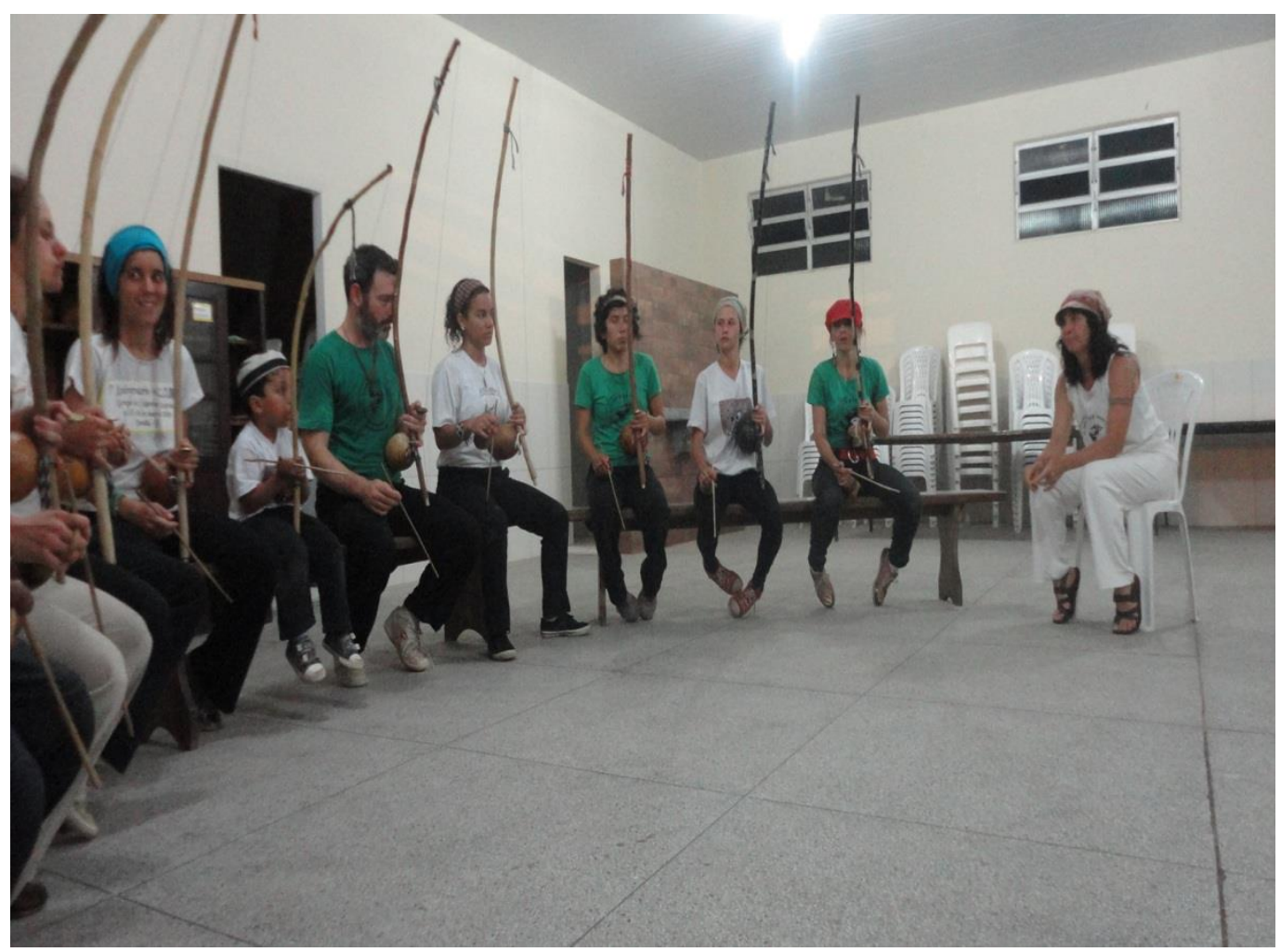

\section{Figura 8: Treino de berimbau no salão do CODEN}

A bateria organizada numa proposta circular criava uma corrente sonora vibrante. Quando cantávamos, também era possível sentir a presença do grupo nos coros dos corridos ou nas chulas das ladainhas. Cada um tinha que ir buscando se afinar 
com a bateria, numa interação sincrônica, nada homogênea. $O$ tempo de cada instrumento, o tempo de cada voz, o tempo de todos em conjunto.

O revezamento dos instrumentos no momento dos treinos criava diversas possibilidades de experimentação e desenvolvimento da musicalidade, o aprendizado com os outros, com as outras. Na capoeira angola o aprendizado da movimentação ou da musicalidade, acontecem principalmente em grupo, com o outro, com a outra, em diálogo sempre. Os cantos dialogam com tudo, pergunta e resposta. Parafraseando Richard Sennet (2012)

Os treinos são a base da atividade musical; treinando música, a capacidade de ouvir adquire importância vital, e, ao ouvir bem, o músico se torna uma pessoa mais cooperativa. (...) nos treinos precisam aprender essa arte, tão contrária ao ego, de ouvir, voltandose para fora. Acredita-se às vezes que o resultado caminha na direção do extremo oposto, com uma verdadeira fusão do músico, que submerge o próprio ego em um conjunto maior. Mas a pura e simples homogeneidade não é o que se busca na música feita em conjunto pois seria um resultado muito monótono. A força e o temperamento da música, pelo contrário, manifestam-se através de pequenos dramas de deferência e afirmação; (...) Entretecer essas diferenças é como manter uma conversação rica.

A capoeira angola é uma arte de resistência, não só por seu contexto histórico de luta e libertação, como também pelas formas de vivenciá-la. Os movimentos da capoeira angola, além de outras habilidades, exigem e proporcionam o encontro com a nossa fortaleza. Assim também acontece no aprendizado da sua musicalidade, desde o ato de “ vergar" um berimbau, até o ato de conseguir segurar um instrumento na bateria. Mesmo a atitude sutil de tocar um instrumento é fortalecedora. Não que seja um ato de força, mas sim uma entrega sutil que fortalece. Este fato foi apontado por uma das crianças que participava do grupo, ela disse: “O que eu mais gosto de tocar é o berimbau, mas não sei tocar direito, tô aprendendo agora. O que eu mais gosto é ele. Quando eu pego ele, depois meu dedo dói, daí fica mais forte. E o berimbau é difícil, é uma coisa nova que estou aprendendo." Essa dor que se revela no corpo traduzida em fortaleza, faz parte de um processo de aprendizagem, possível quando abandonamos nossos estados de conforto, para colaborar com o grupo e compreender que diante da força, o mais importante é não usar a força.

Richard Sennet (2012) ao estudar processos de cooperação e aprendizagem em oficinas de artesanato, se dedicou também à compreensão da resistência e emprego da força no manuseio de instrumentos e confecção de objetos. Relacionou os encontros do 
artesão com a resistência física aos encontros sociais difíceis, onde a arte se torna escola de vida. Aqui é possível fazer um paralelo com a capoeira angola, que por anos vem resistindo sem o emprego da força, por meio de uma mandiga que também é ensinada na prática cotidiana de "vergar" um berimbau, ou talhar a madeira para a confecção dos nossos instrumentos. Assim como afirma o autor:

O artesão tem conhecimento de algo muito importante a respeito do trato com a resistência: não resistir, como alguém que entra em guerra com os nódulos na madeira ou com a resistência da pedra; a maneira mais eficaz consiste em empregar força mínima. (...) Na luta com a resistência encontrada, ficamos mais atentos ao desejo de nos livrar do problema do que ao empenho de entende-lo; em contraste, ao trabalhar com a resistência queremos suspender a frustração pelo fato de encontrar um obstáculo, e enfrentarmos o problema em seus próprios termos. ( SENNET, 2012, p. 253-254)

E é nesse sentido que um camarada do grupo afirmou:

A capoeira me ensina muitas coisas entendeu. Me deixa um espírito legal, me faz sentir o espírito bem forte, me conhecer mais, ficar ligado, ter reação com as coisas, saber enfrentar as coisas.

A conexão que se estabelece com a musicalidade da capoeira está relacionada com diversas habilidades tais como, aprender a confeccionar os instrumentos, aprender a prepará-los e afiná-los, sustentar no dedo mindinho um berimbau. Todos os instrumentos são importantes para compor a bateria: os berimbaus, os pandeiros, o agogô, o reco-reco. o atabaque e o caxixi. A mestra Elma sempre nos falava da importância de aprender a tocar, cantar e valorizar todos os instrumentos da capoeira, cada um era imprescindível. Trazia também os ensinamentos do mestre Pato, sobre a importância do aprendizado da musicalidade na capoeira, de modo que os desenvolvimentos da corporalidade e musicalidade estão intimamente relacionados para a formação e desenvolvimento na capoeira.

Os momentos em que trabalhávamos a musicalidade, nos traziam o aprendizado da sutileza, de saber estar no tempo das outras pessoas e dos outros sons. Cantávamos em coro de modo que todas as vozes tendiam a se encaixar, criando um eco transformador. Todos tinham a abertura para cantar e tocar. As crianças sempre participavam tocando os instrumentos que já conseguiam segurar, costumavam puxar cantos ensinados pela mestra: "Fizemos uma roda e sob orientação da mestra começamos todos tocando o toque de São Bento Grande, a mestra nos mostrava diversos improvisos e viradas. Esse era o momento de errar, de aprender. Depois veio o 
momento de cantarmos e cada um foi puxando um corrido. A camaradinha que tocava o pandeiro, puxou um corrido que a mestra costumava ensinar para as crianças:

\author{
Fui no mato catar cipó \\ Quando entrei no mato \\ Eu vi um menino \\ De uma perna só \\ Era o Saci Pererê \\ Pererê Pererê \\ (Domínio Popular)
}

\title{
6.4 Pequenas doses de saber
}

Quando imaginávamos que a aula havia acabado, outros ensinamentos eram propostos em rodas de conversas que costumavam acontecer após os treinos de movimento e de bateria. Esse era o momento de escutar a mestra falando sobre a capoeira e sua filosofia, era o momento de tirar dúvidas sobre o treino e no decorrer dos diálogos erámos banhados da sabedoria da capoeira angola.

Foram marcantes os diálogos em que a mestra nos trouxe o ponto de vista do mestre Curió, sobre as diferenças entre o jogo e a vadiação. A mestra Elma nos disse que para este mestre o jogo está relacionado com a ideia da competição, onde há ganhadores e perdedores, porém no jogo da capoeira, a vadiação, está relacionada à ideia da brincadeira, da mandinga, onde não há vencedores e perdedores, todos tendem a se beneficiar com o diálogo da vadiação, onde a presença do autocontrole é imprescindível para a liberação da nossa agressividade concomitante ao aprendizado da não - violência . A mestra Elma aproveitou esse ponto de vista para nos falar um pouco sobre a importância de trabalharmos a nossa vaidade, o ego dando espaço para que todos possam brincar, jogar. Uma camarada afirmou:

É muito doido porque a capoeira te dá as ferramentas para bater em alguém né, mas também te dá sobretudo, as ferramentas para não fazer isso. Te dá ferramentas para ter muito mais paciência, respeito. Te ajuda a ter muita humildade porque quando está jogando e alguém te bate, aí te ajuda a controlar seu ego. E se alguém te bate, ali se conhece a si mesma porque se fica ressentida, não pode apelar. E se apela talvez é porque está fraco algo dentro de ti. 
Em uma de nossas conversas uma camarada perguntou sobre a velocidade dos movimentos da capoeira angola. Percebi que gostaria de saber quando deveria " fazer um jogo" mais lento ou mais rápido. Essa pergunta foi consequência de uma aula em que combinamos movimentos em diversas perspectivas, sendo a resposta da mestra, a seguinte:

\begin{abstract}
Essa é só mais uma das combinações infinitas em que cada movimento da capoeira é uma peça que você usa para montar o seu jogo. Nenhum capoeirista joga igual." Ainda assim a mestra aproveitou essa pergunta para discorrer sobre o fato de que a capoeira angola, tem seu ritmo próprio e que este está na contracorrente da aceleração do mundo contemporâneo. Mesmo quando iniciamos um jogo que exige um pouco mais de velocidade, esta não se configura em uma correria afobada, o capoeira age no tempo e pensa para agir. Foi importante para desmistificar a idéia de que a capoeira angola é necessariamente lenta, na verdade ela é desacelerada e mais especificamente ela é no tempo. Capoeira é tempo...
\end{abstract}

Ainda nesta aula houve a abertura para explicar aos camaradas sobre a pesquisa de campo que estava sendo realizada com o grupo e que tinha como foco os processos de ensino e aprendizagem da capoeira angola. Houve um interesse geral que culminou em intervenções por parte dos colegas. Conversamos com liberdade sobre a educação no mundo atual, e um dos pontos levantados pela turma foi a possibilidade de estarmos em um ambiente de aprendizagem onde adultos não estão separados das crianças, onde não há classificação e nem mesmo segregação a partir da faixa etária. Foi apontada também a importância de pais e mães estarem aprendendo juntamente com seus filhos.

Uma camarada interveio ao dizer que para ela, praticar capoeira angola era um ato político de escolher quais os processos educativos gostaria de vivenciar em sua formação, e aproveitou para apontar os percalços da capoeira angola no diálogo com instituições formais de ensino: “A capoeira é bem quista pela escola, pois todos compreendem seus benefícios, mas não há valorização dos mestres e mestras no momento de remunerá-los, por exemplo. Muitas vezes espera-se que os mestres e mestras trabalhem de "graça". Neste momento a mestra Elma demonstrou a sua legítima indignação em relação a essa e outras questões como por exemplo a não existência de uma aposentadoria para os mestres e mestras da capoeira.

A comparação com a educação formal foi inevitável, a partir de então e houve a contribuição de um camarada ao dizer que:

A capoeira angola é um saber que se aprende através do corpo, diferente da escola onde ficam todos sentados absorvendo o que dizem os professores. E se aprende através do corpo sob outro olhar, normalmente de cabeça para baixo. 


\subsection{A roda de capoeira do grupo nZambi}

A roda de capoeira é sem dúvida o ritual mais importante do grupo nZambi. Tudo aquilo que é ensinado e aprendido nas aulas, tende a garantir o empoderamento para a vivência desse ritual. A roda é um grande momento de aprendizado, onde mais uma vez somos confrontados com a dinâmica do trabalho em conjunto sendo que a entrega e a colaboração de cada um é indispensável para garantir a harmonia deste momento. Além disso, na roda de capoeira somos convocados a temperar nossos humores para que haja um efetivo diálogo daqueles que ali se encontram. Sobre o papel social do ritual podemos novamente citar Richard Sennet (2012): “Os rituais são uma maneira de estruturar as trocas simbólicas; estabelecem poderosos vínculos sociais e se têm revelado ferramentas usadas pela maioria das sociedades humanas para equilibrar a cooperação e a competição.” (p. 109)

E complementa:

Os comportamentos ritualísticos dão a impressão de que o celebrante deixou a esfera do tempo ao desempenhar um rito, o rito que lhe foi comunicado pela tradição ou pelos deuses. Os rituais não precisam ter proporções gigantescas; (...) Mas seja cósmico ou pequeno, o ritual parece um comportamento que vem de fora de nós, livrando-nos de tudo que possa ser autorreferencial; nossa atenção fica toda voltada para simplesmente executar bem o ritual. Mas se o ritual se limitasse a ditar um comportamento, se fosse um santuário que não fosse feito por nós mesmos, o rito seria uma força estática - e os rituais não são comportamento congelado." ( p. 111)

Em frente à imagem de São Pedro, de frente para uma montanha, nove instrumentos musicais: três berimbaus, gunga, médio e viola; caxixi, dois pandeiros, agogô, reco-reco e atabaque. A mestra Elma no gunga abria a roda com o toque de angola, berimbau que chama todos para a conversa cósmica da capoeiragem. Bateria formada, o gunga pede dois jogadores. Inicia a ladainha, pra quem recebe é benção. Todos respondem à louvação, inclusive o atabaque que entra dando o tom da sua marcação coronária, ou mesmo como afirmou uma camarada do grupo: o atabaque quando entra, vem como o latido da terra.

A resposta ao coro do corrido pode sinalizar o início do jogo, mas o gunga é quem marca esse tempo. Reverencia os jogadores que buscam o diálogo no ritmo da bateria. E daqui pra diante, cada vez mais, a roda de capoeira é um espaço de 
aprendizado, onde impera uma comunicação sagrada, entre os músicos na bateria, entre aqueles que estão vadiando, enfim entre todas as pessoas que estão presentes.

É como um momento fora do tempo em que vivenciamos inúmeras situações sutis que nos trazem os prazeres e desprazeres da revelação. Medo, vaidade, competitividade. A roda de capoeira estremece a nossa acomodação e nos convida a reagir diante dos imprevistos aos quais ali nos colocamos a prova. Vida e morte. Passagem e iniciação. Roda de capoeira, escola de vida:

A roda é como se fosse uma representação pequena da vida né. Então na roda agente consegue sempre fazer um paralelo com alguma atitude que agente tem na vida. Quando começa uma roda até o momento que ela vai terminar é como se o tempo parasse, a vida parou e agente tenta ficar no aqui e agora e perceber como trabalhar essa coisa fora do tempo, fora da nossa correria da realidade do dia- a - dia, peceber que tem outras forças atuando ali e o que agente pode fazer para que essas forças sejam fluídas, harmoniosas. Sempre que termina a roda agente dá aquele Iê e tem o momento da gente se olhar, pronto, voltou, é como se entrássemos em outra vibração, outra frequência e depois que termina a roda agente volta pra essa vida que agente tá sempre vivendo. ( camarada do grupo nZambi)

Para nós do grupo nZambi, domingo era dia de vadiação, dia de estar com os camaradas e celebrar esse esperado ritual, que na conversa dos cantos e movimentos, nos trazia outro vigor para enfim iniciar novos ciclos com elementos para repensarmos os rumos da nossa prosa.

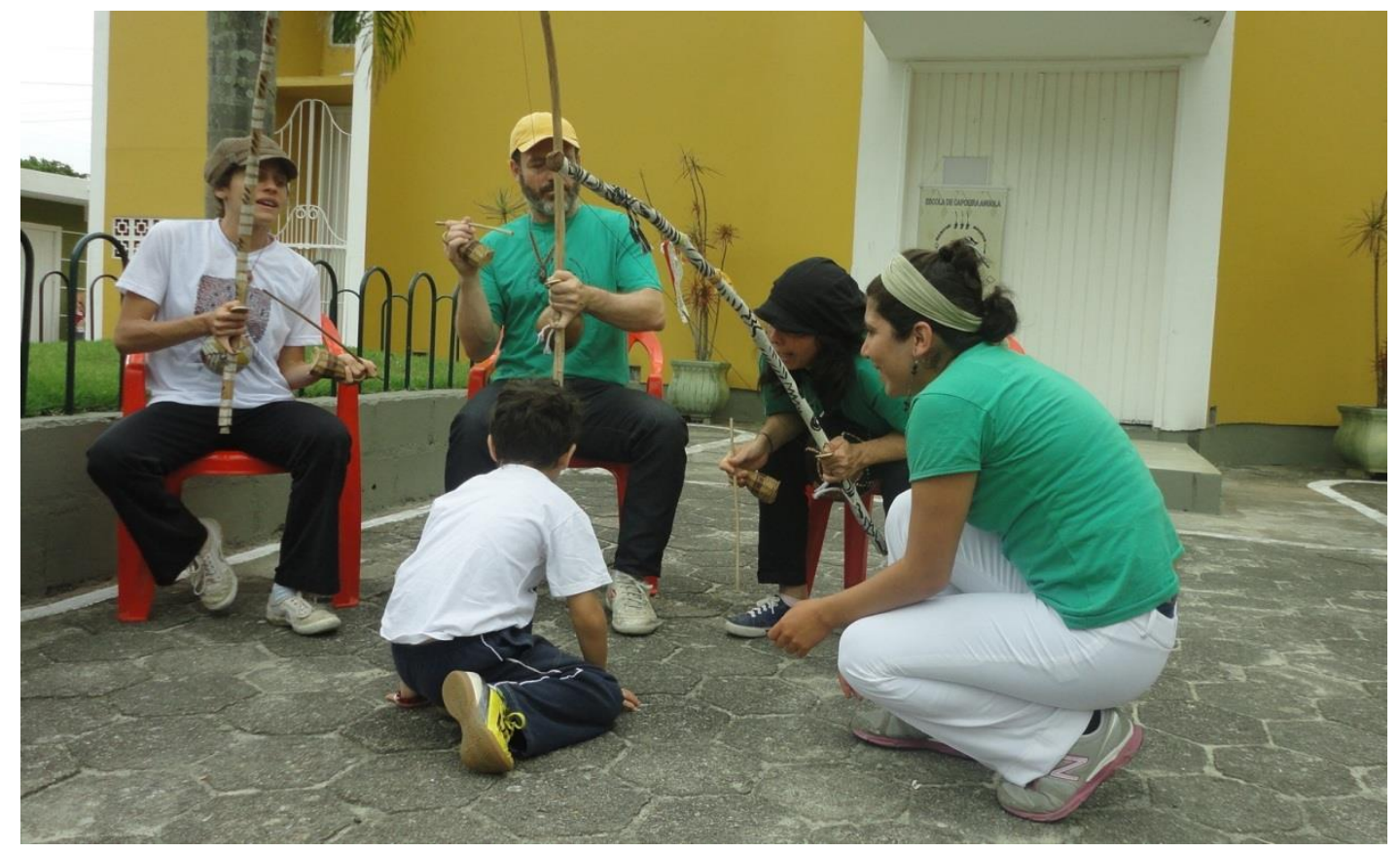

Figura 9: Roda de capoeira em frente à Igreja de São Pedro na região do Pântano do Sul 


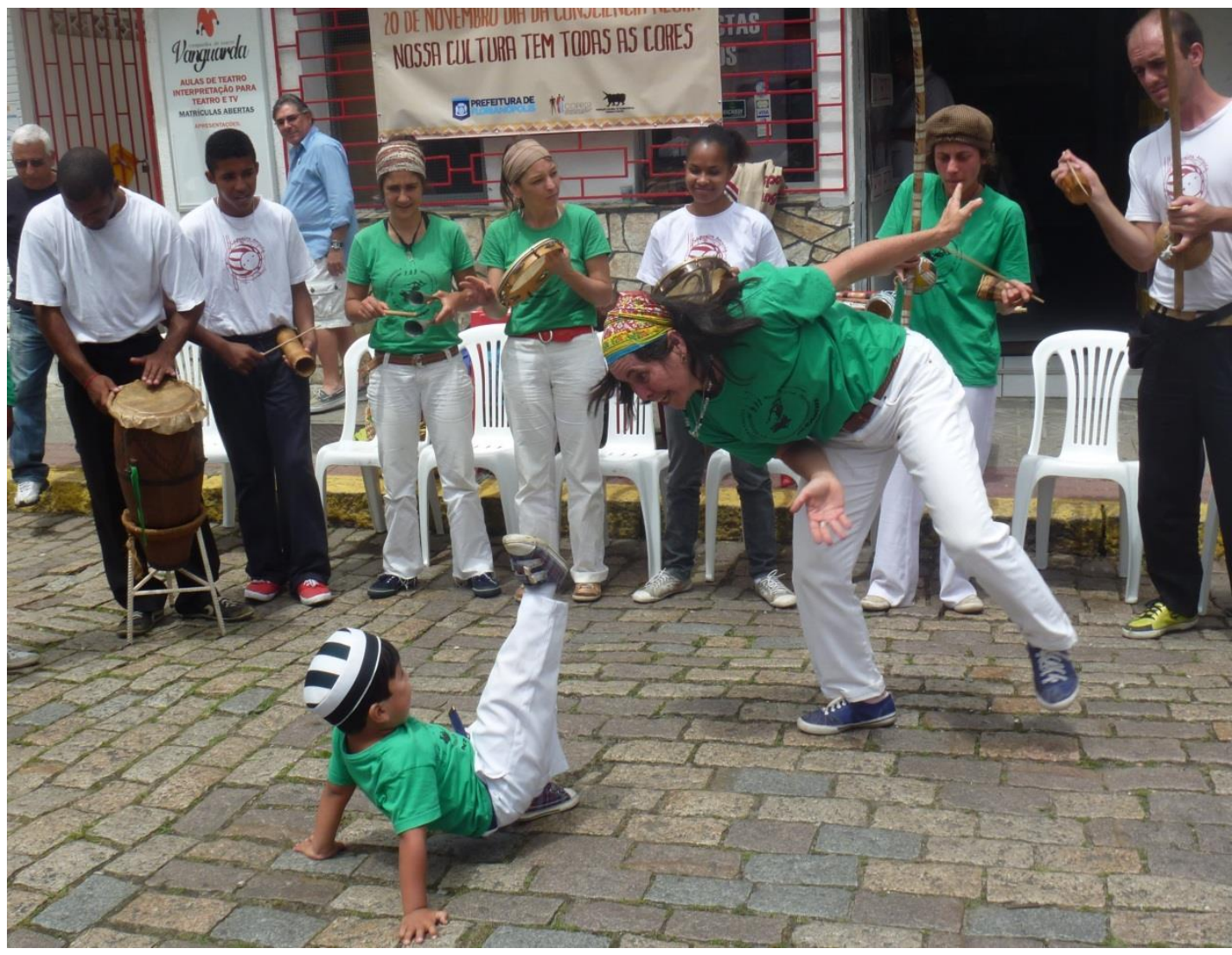

Figura 10: Roda de capoeira em decorrência do dia da " consciência negra", no centro da cidade de Florianópolis 


\section{CONSIDERAÇÕES FINAIS}

O relato que acabamos de tecer, se fez com fios de uma experiência profunda. Espero que cada linha dessa teia possa trazer a reflexão sobre aquilo que nosso olhar conseguiu perceber. Assumo aqui a minha incompletude, logo a incompletude desses relatos. Aqui se encontra muito menos do que essa vivência me ofereceu, ainda hoje me sinto sob efeito de alguns ensinamentos que aos poucos vem se revelando nas situações da vida. Além disso, nem tudo que se apresentou está no papel, há limites que me impedem de ir mais longe.

Àqueles que somente se satisfazem com longas narrativas, peço desculpas. Também peço desculpas, às pessoas que me considerarem verborrágica. Talvez uma longa caminhada me aguarda na descoberta da medida. $\mathrm{O}$ fato é que nós só temos condição de ser o que somos.

Diante do que foi exposto, é possível perceber a capoeira angola como uma manifestação da cultura popular afro-brasileira, como uma verdadeira mãe, nem tão acolhedora que nos deixe acomodar, nem tão severa que nos deixe dilacerar. A capoeira angola é como uma amizade verdadeira, não bajula e muito menos acaricia nosso ego. A cada aprendizado algo se renova, como se trocássemos de pele.

No caso dos trabalhos desenvolvidos pela mestra Elma, identificamos o grupo de capoeira angola como uma comunidade de ensino e aprendizagem, em que corporeidade, musicalidade e filosofia são elementos que convergem na formação de vínculos e modos sutis de interação que dependem de um comportamento cooperativo para a manutenção dos seus rituais. Percebemos que por meio do trabalho coletivo desenvolvíamos a caprichosa arte da cooperação em processos flexíveis de divisão de tarefas, onde a iniciativa do cuidado com todos os aspectos que nos tocavam, alimentavam em nós o sentimento de parte daquele grupo.

Estar no tempo e nas necessidades do coletivo era um dos grandes desafios, que nos convidava a sentir o ambiente que partilhávamos. Além disso, cada um trazia aquilo que era, tornando nosso convívio um trabalho em meio à diversidade, onde o aprendizado em grupo revelava também os conflitos próprios da natureza humana, a arte do relacionar em esfera prática nos ensinava a importância da " hora de acordar" e reagir a necessidades além daquelas que nos são pessoais: 
não poderíamos nos desenvolver como indivíduos no isolamento. Mas isso significa que os próprios desentendimentos, separações, objetos transicionais e autocríticas que se manifestam ao longo do desenvolvimento representam testes sobre a maneira como se relacionar com as outras pessoas, e não sobre como hibernar. (SENNET, 2012, p. 25)

A circularidade da capoeira angola, era vivenciada por nós a todo momento. Nos treinos e nas rodas vivenciávamos o aprendizado sagrado de uma arte que no tom cósmico do círculo trazia ensinamentos para a libertação onde não nos esquecíamos da constante presença das outras pessoas. Não estávamos sozinhos. E apesar do silêncio, e justamente pelo silêncio nenhuma troca era superficial. Sem o vício da verborragia, ou mesmo no trabalho desta dimensão, tudo dizia. Corpo, ambiente, gestos, olhares e temperaturas. Sons, intuição. Toda a energia voltada para o ensinamento de aprender fazendo. A formação que surge no envolvimento direto com um saber que antes de mais nada é experiencial.

Em grupo era possível experimentar o auto-conhecimento, o auto-cuidado, a cooperação e a não-violência, valores hoje considerados de grande importância para a transformação da sociedade individualista e competitiva na qual estamos vivendo. $\mathrm{O}$ tempo, o tato e a respiração, o silêncio e a observação, imprescindíveis aos saberes que se transmitem por meio da oralidade.

Por meio da repetição, a capoeira angola nos impregnava de movimento, música, filosofia, fundamentos. Escola de vida, aprendizados de serpente. A mandinga da não resistência, na sabedoria do artesanato que não briga com os nódulos da madeira, na sabedoria da água, nunca passiva sempre transpondo. A malícia da percepção, a observação, o olhar às outras pessoas. $\mathrm{O}$ olho nas costas. A irreverência da vadiação, o jogo vadiado que não comporta a valentia e não cabe a vaidade.

Processo de ensino e aprendizagem onde crianças e adultos aprendiam juntos, saber ancestral, que tem como base o respeito aos mais velhos e o convívio comum no ensinamento de habilidades para a vida. Crianças, adultos, homens, mulheres, pessoas que nasceram no Brasil, pessoas que nasceram em outros países, no desafio do aprendizado que emerge do convívio com as diferenças. Os momentos de aprendizagem de cada pessoa e cada qual nos momentos de aprendizagem do grupo.

$\mathrm{Na}$ roda de capoeira vida e morte, passagem, iniciação. Como afirma mestre Pato: “ Uma roda de fundamento em harmonia, não só encanta como eleva, como massageia, espiritualiza, autoafirma a personalidade." (Guesa Errante: suplemento 
cultural e literário JP, 2012, p. 3). Ambiente de celebração, ritual possível na doação e verdadeira interação do grupo. Roda de capoeira que nos ensina a arte de aprender.

Essa pequena parte do que relato foi aquilo que durante três meses de vivência saltou aos olhos de uma pessoa que chegou à ilha das bruxas com fome de capoeira. A ansiedade que acompanha determinados apetites de nada resulta. Não se aprende capoeira do dia para noite, a capoeira não se resume em tão poucas páginas. Normalmente morremos sem saber, porque vivemos aprendendo. Porém neste trabalho foi aceito o desafio de trazer um conhecimento a partir do que se conhece sobre ele, a partir do quanto nos tornamos aquilo sobre o qual buscamos refletir. Este é um trabalho em que me coloco. Estou como angoleira e também como alguém que percebe a capoeira angola como uma escola e como uma filosofia de vida. À partir do que foi explicitado entendo a capoeira angola como saber e as mestras e mestres de capoeira como pessoas que dedicam suas vidas à arte de aprender e ensinar. São ofícios da madeira, do arame, da cabaça e do trato. Ensinamentos dos gestos, do corpo e da música.

Capoeira angola, escola que surge como uma das iniciativas da sua perseverança no tempo e no espaço. Saber que dentre tantos outros, é inexistente sob os olhos de um pós-colonialismo que ainda opera por um sistema de monoculturas, dentre elas a monocultura do saber . Apesar do cânone hegemônico do conhecimento científico e das inúmeras represálias do Estado, essa manifestação da cultura popular afro-brasileira, resiste. Sem brigar com nódulos da madeira, e sim gingando diante das situações, criando e recriando possibilidades, sabendo cair e levantar, invertendo para reverter. Sofisticado jogo de milímetros.

Hoje temos a possibilidade de abordar essa questão junto à comunidade acadêmica, alguns anos antes esse trabalho seria até uma afronta à nação brasileira. Em confronto à essa lógica, nos ampara a ecologia dos saberes ao reconhecer a infinitude dos conhecimentos, bem como o direito de que cada saber sendo como é tenha garantida sua legitimidade de diálogo horizontal com qualquer outro saber.

Neste sentido a capoeira angola é uma manifestação da cultura popular afrobrasileira, com um sistema próprio de transmissão de saber. É ritualística e na expressão da sua musicalidade e corporeidade, vivenciamos fundamentos ancestrais. O critério de legitimação do saber se dá pela via do reconhecimento. A capoeira angola possui sua 
própria lógica de organização, o que não implica em sua supremacia sobre outras manifestações de saber.

Ao longo dos tempos, a capoeira angola buscou eixos de diálogo com diversos saberes, inclusive com instituições orientadas pelo pensamento hegemônico ocidental, tal como o Estado. "Vira e mexe" essa prosa culminava em tentativas de domínio da autonomia da comunidade angoleira. Estamos distantes de uma ecologia dos saberes. Não raro nos deparamos com diversos projetos de lei que buscam regulamentar a profissão do capoeirista, sob moldes institucionais que não representam de fato o ofício da capoeiragem.

Realizar o diálogo entre a capoeira angola e a ecologia dos saberes nos permite ampliar a conversa em torno da diversidade epistemológica que existe no mundo. Além disso, a própria capoeira angola é um saber que trabalha as inúmeras dimensões da pessoa em um sistema de formação que é diverso, lúdico, não-linear e vivencial. Na ecologia da capoeira encontramos a circularidade, a corporeidade, a musicalidade, a filosofia e uma temporalidade não linear fundamentada principalmente na memória e ancestralidade.

Esperamos com esse trabalho poder contribuir com medidas que estejam atentas à diversidade do mundo no qual vivemos aqui no caso à diversidade de saberes, à ecologia dos saberes. Aqui a monocultura dos saberes foi confrontada no reconhecimento da capoeira angola como um saber, um espaço para a vadiação onde o processo de formação e auto-formação acontecem em uma perspectiva ecológica, complexa e sistêmica. Assim, partindo da perspectiva da ecologia dos saberes brincamos com as palavras e sem resistir aos trocadilhos podemos dizer que este trabalho, antes de qualquer coisa foi um trabalho sobre a ecologia da vadiação. 


\section{REFERÊNCIAS}

ABIB, Pedro Rodolpho Jungers. Capoeira Angola: cultura popular e o jogo de saberes na roda. Campinas, SP. Unicamp/ CMU; Salvador: EDUFBA, 2005.

Roda de capoeira angola e a força do canto do poeta. Sociedade $e$ cultura.Goiânia, v.5, n.1, 2002.

ARENDT, Hannah. A condição humana. 10. ed. Rio de Janeiro: Forense Universitária, 2007.

ASSIS JUNIOR, António de. Dicionário Kimbundu - Português. Luanda: Edição de Argente, Santos. s/d.

ASSUNÇÃO, Mathias Röhrig; COBRA MANSA, Mestre. A dança da zebra. In: FIGUEIREDO, Luciano (org.). Raízes africanas. Rio de Janeiro: Sabin, 2009, p. 62-69.

BARRETO, Paulo. Capoeira angola e candomblé. In: Revista do grupo Nzinga de Capoeira Angola: Toques D' Angola. Brasília, São Paulo e Salvador: INCAB, novembro de 2005.

BOFF, Leonardo. Princípio-Terra: a volta à terra como pátria comum. São Paulo: Editora Ática, 1995.

BOLA SETE, Mestre. A capoeira angola na Bahia. 2. ed. Rio de Janeiro: Pallas, 1997.

GAFANHOTO; KAU; MARROM; PALITO; PRÍNCIPE; TERNO E ÁS; VOLTA AO MUNDO; WALDIR PERIGO (Colaboradores). Canjiquinha Alegria da Capoeira. Salvador: Editora A rasteira, 1989.

CANJIQUINHA, Mestre. Autobiografia. Salvador, setembro de 1986.

CASCAES, Franklin. O fantástico na Ilha de Santa Catarina. Florianópolis: Ed. da UFSC, 2012.

CASCUDO, Luís da Câmara. Made in África. Rio de Janeiro: Editora Civilização Brasileira S.A, 1965. 
CERTEAU, Michel de. A invenção do cotidiano: 1 Artes de fazer. Tradução de Ephraim Ferreira Alves. 18. ed. Petrópolis, RJ: Vozes, 2012.

CRESWELL, John W. Projeto de Pesquisa: métodos qualitativo, quantitativo e misto. 3. ed. Porto Alegre: Artmed, 2010.

DOMÍNGUEZ, María Eugenia. Rodas de Capoeira: arte e patrimônio em Florianópolis. Florianópolis: Contraponto, 2010.

FALCÃO, José Luiz Cirqueira. A escolarização da capoeira. Brasília: ASEFE- Royal Court, 1996.

. O jogo da capoeira em jogo e a construção da práxis capoeirana. Salvador, 2004. Tese ( Doutorado em Educação) - Universidade Federal da Bahia.

GUATTARI, Félix. As três ecologias. Campinas, SP: Papirus, 1990.

GADOTTI, Moacir . História das idéias pedagógicas. 8. ed. São Paulo: Editora Ática, 2003.

JUNG, Carl G (organizador). O Homem e seus Símbolos. 5. ed. Rio de Janeiro: Editora Nova Fronteira. 1964.

LEAL, Luiz Augusto Pinheiro; OLIVEIRA, Josivaldo Pires de. Capoeira, identidade e gênero: ensaios sobre a história social da capoeira no Brasil. Salvador: EDUFBA, 2009.

LIMA, Mônica. Venho de Angola, camará. In: FIGUEIREDO, Luciano (org.). Raízes africanas. Rio de Janeiro: Sabin, 2009, p.11-15.

MACHADO, Sara Abreu da Mata; ABIB, Pedro Rodolpho Jungers. Corpo, ancestralidade e africanidade: por uma educação libertadora no jogo da capoeira angola. In: Entrelaçando - Revista Eletrônica de Cultura e Educação. Caderno temático: Educação e Africanidades. 2011.

MAGALHÃES FILHO, Paulo Andrade. Jogo de Discursos: a disputa por hegemonia na tradição da capoeira angola baiana. Salvador: EDUFBA, 2012.

PEREIRA, Rita Marisa Ribes. A pesquisa como experiência estética. In: PASSOS, Mailsa Carla Pinto; PEREIRA, Rita Marisa Ribes (Orgs). Educação Experiência Estética. Rio de Janeiro: Nau, 2011. p. 227-239. 
PASTINHA, Vicent Ferreira. Improviso de Pastinha. Organização de Fred Abreu. Salvador, 2013.

PATO, Cláudia. Valores ecológicos. In: CAVALCANTE, S; ELALI, G.A. (Orgs.). Temas básicos em psicologia ambiental. Petrópolis, RJ: Vozes, 2011. p. 296-305.

SANTOS, Boaventura de Souza. A gramática do tempo: para uma nova cultura política. 3. Ed. São Paulo: Cortez, 2010. Um discurso sobre as ciências. 7. ed. São Paulo: Cortez, 2010.

SENNETT, Richard. Juntos. Tradução de Clóvis Marques. Rio de Janeiro: Record, 2012.

SILVA, Mellissa Fernanda Gomes da; SOUZA, Thiago Vieira; SOUZA NETO, Samuel de. $O$ mestre de capoeira angola ensina pegando pela mão: saberes, artefatos e rituais no processo de formação. São Paulo: Cultura Acadêmica, 2011.

SOARES, Carlos Eugênio Líbano. A capoeira escrava e outras tradições rebeldes no Rio de Janeiro (1808-1850). 2. ed. rev. e ampl. Campinas, SP. Unicamp, 2004.

Prefácio. In: LEAL, Luiz Augusto Pinheiro; OLIVEIRA, Josivaldo Pires de. Capoeira, identidade e gênero: ensaios sobre a história social da capoeira no Brasil. Salvador: EDUFBA, 2009.

\section{Matérias de jornais}

CAPOEIRA, uma tradição renovada. O Imparcial. São Luís. 17 de dezembro de 2010.

MESTRE PATO, o capoeira poeta das expressões corporais. Guesa Errante: suplemento cultural e literário JP. São Luís. 11 de Fevereiro de 2012, sábado, p.2-3.

\section{Relato oral}

WEBA, Mestra Elma Silva. 2012-2013. Relatos concedidos à pesquisa intitulada $A$ ecologia da vadiação: os saberes no grupo nZambi de capoeira angola em Florianópolis, Santa Catarina. Entrevistadora: RABELO, Isabela Guimarães. Locais: Brasília e Florianópolis. 


\section{APÊNDICE A: ROTEIRO DE ENTREVISTA SEMI-ESTRUTURADA N ${ }^{\circ} 1$ DIRIGIDA À MESTRA ELMA}

TÍTULO DA PESQUISA: A ecologia da vadiação: os saberes no grupo nZambi de capoeira angola em Florianópolis - SC

PESQUISADORA RESPONSÁVEL: Isabela Guimarães Rabelo

Roteiro de Entrevista Semi-Estruturada $\mathbf{N}^{\circ} 1$ - mestra Elma

1- Há quanto tempo você se dedica a capoeira?

2- Como foi o seu encontro com a capoeira?

3- Você nasceu em que região do Estado do Maranhão?

4- Em São Luís do Maranhão você vivia com sua família?

5 - Me fale um pouco sobre os trabalhos desenvolvidos em Florianópolis... 


\section{APÊNDICE B: ROTEIRO DE ENTREVISTA SEMI-ESTRUTURADA N ${ }^{\circ}$} DIRIGIDA A MESTRA ELMA

TÍTULO DA PESQUISA: A ecologia da vadiação: ensinamentos do grupo nZambi de capoeira angola em Florianópolis - SC

PESQUISADORA RESPONSÁVEL: Isabela Guimarães Rabelo

Roteiro de Entrevista Semi-Estruturada $\mathbf{N}^{\circ} 2$ - mestra Elma

1 - Você poderia me falar um pouco sobre o grupo nZambi?

2 - Como ele surgiu?

3 - Qual o significado do nome nZambi?

4 - Como foi a sua chegada a Porto Alegre?

5 - Quais eram as frentes de trabalho do nZambi por lá?

6- O que te levou a Brasília? 


\section{APÊNDICE C: ROTEIRO DE ENTREVISTA SEMI-ESTRUTURADA N 3 DIRIGIDA A MESTRA ELMA}

TÍTULO DA PESQUISA: A ecologia da vadiação: ensinamentos do grupo nZambi de capoeira angola em Florianópolis - SC

PESQUISADORA RESPONSÁVEL: Isabela Guimarães Rabelo

\section{Roteiro de Entrevista Semi-Estruturada $N^{\circ} 3$ - mestra Elma}

1- Como foi a trajetória do nZambi em Brasília?

2- Como eram os trabalhos no Terreiro do Vô Congo?

3- Houve a participação de todos os integrantes do grupo?

4- Qual o seu parentesco com a Mãe Zenit de Oxum?

5- Você desenvolveu os trabalhos do nZambi em Brasília por quanto tempo?

6- Quando você se mudou para Florianópolis, deixou responsáveis pelo nZambi em Brasília?

7- Qual foi o critério de escolha dessas pessoas?

8- Como foi o início dos trabalhos em Florianópolis?

9- Quando você iniciou o trabalho na região da Costa de Dentro?

10- Como foi o processo do seu reconhecimento como mestra? 


\section{APÊNDICE D: ROTEIRO DE ENTREVISTA SEMI-ESTRUTURADA N ${ }^{\circ}$ DIRIGIDA AOS CAMARADAS DO GRUPO N'ZAMBI}

TÍTULO DA PESQUISA: A ecologia da vadiação: ensinamentos do grupo nZambi de capoeira angola em Florianópolis - SC

PESQUISADORA RESPONSÁVEL: Isabela Guimarães Rabelo

\section{Roteiro de Entrevista Semi-Estruturada $\mathrm{N}^{\circ} 1$ - Camaradas do grupo nZambi}

1- Qual a sua idade?

2- Você pratica capoeira à quanto tempo?

3- Como foi seu primeiro contato com a capoeira?

4- Como você chegou até esse grupo de capoeira?

5- $\mathrm{O}$ que te motiva a praticar capoeira?

6- O que é ensinado nas aulas de capoeira?

7- O que você percebe que aprende com a capoeira?

8- Na capoeira angola não há provas, nem rituais de formatura. Como você sabe que está aprendendo?

9- O que você acha da seguinte afirmação: a capoeira angola é uma escola de vida.

10- Como você se sente após iniciar a prática da capoeira: quais foram os benefícios para o seu corpo? E nos aspectos mentais e emocionais?

11- A capoeira mudou algo na forma como você vê o mundo?

12- Aqui no grupo os treinos contam com presenças variadas: adultos, idosos, crianças. $\mathrm{O}$ que você acha de treinar capoeira em um ambiente com pessoas de várias idades?

13- Na sua percepção, o que é ser um capoeirista?

14- Para você a capoeira é... 


\section{APÊNDICE E: ROTEIRO DE ENTREVISTA SEMI-ESTRUTURADA N5 DIRIGIDA A VICE - PRESIDENTA DO CODEN}

TÍTULO DA PESQUISA: A ecologia da vadiação: ensinamentos do grupo nZambi de capoeira angola em Florianópolis - SC

PESQUISADORA RESPONSÁVEL: Isabela Guimarães Rabelo

Roteiro de Entrevista Semi-Estruturada $\mathbf{N}^{\circ} 5$ - vice-presidenta do CODEN

1- Há quanto tempo existe o CODEN?

2- Quais são as principais atribuições do CODEN?

3- Quais atividades são desenvolvidas pelo CODEN?

4- Qual é o acesso da comunidade ao CODEN?

5- Como você percebe a presença da capoeira angola aqui no CODEN? 


\section{APÊNDICE F: ROTEIRO DE OBSERVAÇÃO PARTICIPANTE DAS AULAS DO GRUPO N'ZAMBI}

TÍTULO DA PESQUISA: A ecologia da vadiação: ensinamentos do grupo nZambi de capoeira angola em Florianópolis - SC

PESQUISADORA RESPONSÁVEL: Isabela Guimarães Rabelo

Roteiro de Observação Participante - Aulas do grupo nZambi

1- Ambiente das aulas

2- Descrição cronológica dos fatos

3- Como se seguiu a aula

4- Como foi a interação de todos

5 - Quais saberes foram trabalhados? Como?

6- Como as pessoas se comportavam nas trocas de saberes?

7- Como a mestra trabalhou as dúvidas e dificuldades do grupo?

8- O que foi dito? 


\section{APÊNDICE G: TERMOS DE CONSENTIMENTO PARA REALIZAÇÃO DA ENTREVISTA E USO DE IMAGENS}

Universidade de Brasília

Faculdade de Educação

Programa de Pós-Graduação em Educação

\section{Termo de Consentimento Livre e Esclarecido - TCLE}

\section{Prezado(a) Entrevistado (a):}

A pesquisa intitulada "A ECOLOGIA DA VADIAÇÃO: AS TROCAS DE SABERES DO GRUPO N'ZAMBI DE CAPOEIRA ANGOLA" pretende compreender a ecologia da capoeira angola através daquilo que emerge das trocas de saberes no ambiente do grupo N'Zambi de capoeira angola em Florianópolis-Santa Catarina . Para tanto, será desenvolvida por meio de um estudo de caso com os integrantes desse grupo de capoeira que desenvolve suas atividades no Conselho Comunitário da Costa de Dentro, em Florianópolis, Santa Catarina, com foco na prática pedagógica da Mestra Elma.

O estudo será realizado com participação voluntária dos sujeitos de pesquisa. Nesse sentido, solicitamos a sua autorização para a realização desta entrevista.

Esclarecemos que a participação não implicará em qualquer despesa pessoal, custo ou dano para os participantes. Do mesmo modo, não haverá qualquer ganho financeiro para os mesmos.

Destacamos que as informações obtidas pela pesquisadora serão sigilosas e tratadas exclusivamente com fins acadêmicos e científicos. Além disso, as pessoas envolvidas não serão identificadas em nenhuma etapa do estudo. Com exceção da mestra Elma que será identificada em todas as etapas.

Asseguramos aos participantes o direito de se retirar do estudo a qualquer momento, sem qualquer prejuízo. E informamos que a qualquer momento você poderá entrar em contato com a pesquisadora, Isabela Rabelo, para esclarecimentos e dúvidas, pelo telefone (48)98232883 ou endereço eletrônico: belagrabelo@gmail.com. 
Por fim, esclarecemos que esta pesquisa faz parte do mestrado em Educação da Universidade de Brasília, sob a orientação da Prof ${ }^{a} \operatorname{Dr}^{\mathrm{a}}$ Claudia Pato (claudiap@unb.br) e conta com apoio financeiro da Coordenação de Aperfeiçoamento de Pessoal de Nível Superior - CAPES, do Ministério da Educação - MEC.

O presente documento foi elaborado em duas vias. Uma ficará com a pesquisadora responsável e a outra com a pessoa entrevistada.

Entrevistado (a)

Isabela Guimarães Rabelo

Pesquisadora Responsável

Matrícula: 12/0048388/UnB/PPGE

Florianópolis, __ de novembro de 2013 
Universidade de Brasília

Faculdade de Educação

Programa de Pós-Graduação em Educação

\section{Termo de Consentimento Livre e Esclarecido - TCLE}

\section{Prezado(a) Presidente do Conselho Comunitário da Costa de Dentro - CODEN:}

A pesquisa intitulada "A ECOLOGIA DA VADIAÇÃO: AS TROCAS DE SABERES DO GRUPO N'ZAMBI DE CAPOEIRA ANGOLA" pretende compreender a ecologia da capoeira angola através daquilo que emerge das trocas de saberes no ambiente do grupo N'Zambi de capoeira angola em Florianópolis-Santa Catarina . Para tanto, será desenvolvida por meio de um estudo de caso com os integrantes desse grupo de capoeira que desenvolve suas atividades no Conselho Comunitário da Costa de Dentro, em Florianópolis, Santa Catarina, com foco na prática pedagógica da Mestra Elma.

O estudo será realizado com participação voluntária dos sujeitos de pesquisa. Nesse sentido, solicitamos a sua autorização para a realização desta pesquisa no Conselho Comunitário da Costa de Dentro - CODEN.

Esclarecemos que a participação não implicará em qualquer despesa pessoal, custo ou dano para o CODEN a criança ou jovem. Do mesmo modo, não haverá qualquer ganho financeiro para esta instituição.

Destacamos que as informações obtidas pela pesquisadora serão sigilosas e tratadas exclusivamente com fins acadêmicos e científicos. Além disso, as pessoas envolvidas não serão identificadas em nenhuma etapa do estudo. Com exceção da mestra Elma que será identificada em todas as etapas.

Asseguramos aos participantes o direito de se retirar do estudo a qualquer momento, sem qualquer prejuízo. E informamos que a qualquer momento você poderá entrar em contato com a pesquisadora, Isabela Rabelo, para esclarecimentos e dúvidas, pelo telefone (48)98232883 ou endereço eletrônico: belagrabelo@gmail.com.

Por fim, esclarecemos que esta pesquisa faz parte do mestrado em Educação da Universidade de Brasília, sob a orientação da Prof ${ }^{a}$ Dr $^{a}$ Claudia Pato (claudiap@unb.br) 
e conta com apoio financeiro da Coordenação de Aperfeiçoamento de Pessoal de Nível Superior - CAPES, do Ministério da Educação - MEC.

O presente documento foi elaborado em duas vias. Uma ficará com a pesquisadora responsável e a outra com presidente (a) responsável pelo Conselho Comunitário da Costa de Dentro..

Presidente (a) do CODEN

Isabela Guimarães Rabelo

Pesquisadora Responsável

Matrícula: 12/0048388/UnB/PPGE

Florianópolis, __ _ de novembro de 2013 
Universidade de Brasília

Faculdade de Educação

Programa de Pós-Graduação em Educação

\section{Termo de Consentimento Livre e Esclarecido - TCLE}

\section{Prezado(a) Responsável:}

A pesquisa intitulada "A ECOLOGIA DA VADIAÇÃO: AS TROCAS DE SABERES DO GRUPO N'ZAMBI DE CAPOEIRA ANGOLA" pretende compreender a ecologia da capoeira angola através daquilo que emerge das trocas de saberes no ambiente do grupo N'Zambi de capoeira angola em Florianópolis-Santa Catarina . Para tanto, será desenvolvida por meio de um estudo de caso com os integrantes desse grupo de capoeira que desenvolve suas atividades no Conselho Comunitário da Costa de Dentro, em Florianópolis, Santa Catarina, com foco na prática pedagógica da Mestra Elma.

O estudo será realizado com participação voluntária dos sujeitos de pesquisa. Nesse sentido, solicitamos a sua autorização para a realização desta entrevista, enquanto adulto responsável pela criança ou jovem que será entrevistado (a).

Esclarecemos que a participação não implicará em qualquer despesa pessoal, custo ou dano para a criança ou jovem. Do mesmo modo, não haverá qualquer ganho financeiro para os mesmos.

Destacamos que as informações obtidas pela pesquisadora serão sigilosas e tratadas exclusivamente com fins acadêmicos e científicos. Além disso, as pessoas envolvidas não serão identificadas em nenhuma etapa do estudo. Com exceção da mestra Elma que será identificada em todas as etapas.

Asseguramos aos participantes o direito de se retirar do estudo a qualquer momento, sem qualquer prejuízo. E informamos que a qualquer momento você poderá entrar em contato com a pesquisadora, Isabela Rabelo, para esclarecimentos e dúvidas, pelo telefone (48)98232883 ou endereço eletrônico: belagrabelo@gmail.com.

Por fim, esclarecemos que esta pesquisa faz parte do mestrado em Educação da Universidade de Brasília, sob a orientação da Prof ${ }^{a} \operatorname{Dr}^{a}$ Claudia Pato (claudiap@unb.br) 
e conta com apoio financeiro da Coordenação de Aperfeiçoamento de Pessoal de Nível Superior - CAPES, do Ministério da Educação - MEC.

O presente documento foi elaborado em duas vias. Uma ficará com a pesquisadora responsável e a outra com o adulto responsável pela criança ou jovem entrevistado (a).

Responsável pelo (a) entrevistado (a)

Isabela Guimarães Rabelo

Pesquisadora Responsável

Matrícula: 12/0048388/UnB/PPGE

Florianópolis, __ _ de novembro de 2013 
